\title{
THE TRAGEDY OF DISTRUST IN THE IMPLEMENTATION OF FEDERAL ENVIRONMENTAL LAW
}

\author{
Richard J. Lazarus*
}

INTRODUCTION

In the dream, it works something like this: The huge hall of Environmental Control is lit from above. Operators below press controls and the translucent dome glows with the streams slashing the Upper Atmosphere, shaping the world's weather. Other controls are pressed and the flow changes color. Now it illuminates the Middle Atmosphere over America, showing regional smog-bearing inversions that may lock over cities within hours. In and out of walls glide panels on which river basins shine with flood-crest warnings or change hue to show rise and fall of pollution .... Nearby, in the Surveillance Center of Environmental Health Services, pesticides, oxides, nitrates, adulterants, all 30,000 chemicals used by industry or everyday life are indexed, cross-referenced, computerized for interaction and contaminations. ${ }^{1}$

Author Theodore White offered this fantastical description of a federal environmental agency just two weeks before President Nixon transmitted to Congress on July 9, 1970 his long-awaited executive order proposing the creation of the United States Environmental Protection Agency ("EPA"). 2 Were EPA's performance now to be measured, more than twenty years later, against that of the mythical agency in White's dream, many would consider EPA a colossal failure. Surely, however, no one would use such a yardstick to judge EPA. White's portrait was not intended to reflect reality.

Imagine nonetheless that Congress had rejected the President's proposal back in 1970 and enacted in its place enabling legislation creating an EPA more akin to that fantasized by White. Also imagine that the statute mandated that the new EPA achieve that level and type of environmental control within six months.

Faced with an impossible task, EPA might have adopted a "loose" construction of the law under which it could reject such an approach based on

Copyright $\odot 1991$ by Law and Contemporary Problems

* Associate Professor of Law, Washington University, St Louis.

I would like to thank Richard Stewart for encouraging me to undertake this project and Jeannette Austin, John Drobak, Lakshman Guruswamy, Michael Kellogg, Jim Krier, Ron Levin, Dan Mandelker, Arnold Reitze, Joe Sax, Gary Schwartz, and Chris Schroeder for commenting on earlier drafts. Kathleen Lindenberger and Cathy Varley provided valuable research assistance. This article was first prepared for the symposium commemorating the twentieth anniversary of the creation of the EPA held at Duke University School of Law on November 15-16, 1990.

1. Theodore $\mathrm{H}$. White, The Nixon Administration Has Drawn lp Its Plan to Untangle the Environmental Jungle-But There Are Problems-How Do W'e Get from Here to There?. Life 36, 37-38 (June 26. 1970).

2. Reorganization Plan No 3 of 1970, 5 USC Reorg Plan of 1970 No 3, App (1988). 
the law's impracticability. A court, however, would likely have overturned the agency's construction, thereby compelling EPA to spend substantial resources in making a good faith, albeit futile, effort to comply with the congressional mandate. Significant institutional obstacles would then have quickly arisen. The Office of Management and Budget ("OMB") would invariably have opposed such a wasteful expenditure of monies. Heads of other federal agencies would have likely expressed opposition based on the program's potential interference with the operation of their own programs. State government officials would have been concerned with its federalism implications. The congressional appropriations committees, feeling the pressure to fund other programs competing for scarce federal dollars, would likely have provided EPA with only limited funds to develop an environmental control command center of such dubious efficacy. Those on the appropriations committees concerned about the impact on free market forces, other federal programs, or federalism, might have also placed riders on EPA's appropriations, limiting the agency's ability to spend funds on certain aspects of the program.

When EPA failed to meet the statutory deadline, the congressional subcommittees that drafted the agency's enabling law would have condemned the agency at oversight hearings. Those subcommittees would also have secured passage of legislation imposing additional deadlines on the agency and eliminating the agency's substantive discretion to ensure future agency compliance.

At EPA, the resulting crisis atmosphere would have stifled pollution control efforts. Agency resources would have been spent preparing for litigation, testifying before oversight hearings, placating state officials, and justifying agency expenditures on the program to skeptical OMB and White House officials. EPA officials would have created numerous working groups to consider how, in the absence of any foundation in science or technology, they might have created the type of highly centralized system of command and control envisioned by Congress. Because of the pending litigation, the agency's lawyers would have displaced other agency professionals (scientists, engineers, and economists) in developing the agency's response. OMB would have sought to delay any implementation of the plan. When the program was finally promulgated, affected industries would have promptly sought a federal court injunction barring any effort by EPA to implement a program disruptive of industry's vested economic interests. Based on the program's severe economic impact and the thinness of its scientific support, the court would have likely granted the injunction and remanded to EPA for further administrative proceedings.

Within EPA, the congressional, judicial, and public demand for immediate results would have discouraged long-term planning. The pall of suspicion cast upon the agency's motives by repeated failures would have likewise deterred innovation. The agency's inevitable loss of credibility before Congress, the courts, and the public would have decreased its influence in 
those forums. As a result, the agency's own perception of national environmental priorities would have increasingly diverged from that of the public and its elected representatives, leading to increasingly inflexible programs mandated by Congress. Because most of the agency professionals were attracted to EPA by a strong sense of its mission rather than by hope of significant monetary reward, their consequent demoralization would have prompted quick turnover and the loss of sustained agency expertise. Needless and irreversible degradation of the natural environment would have continued.

The imagined scenario should seem highly improbable, if not absurd. Congress would never mandate that an agency perform the impossible, decline to appropriate the funds necessary for a good faith effort in the mandated direction, and then condemn the agency publicly for trying and failing. Nor would any such philosophical schism concerning environmental protection policy persist between the executive and legislative branches, thus placing a federal agency charged with the policy's implementation in an untenable position. After all, both the president and Congress are responsive to the same electorate. Finally, there should be no reason to believe that courts would order EPA to take certain action, only subsequently to impede the agency's specific efforts at achieving the judicial mandate.

A review of EPA's last twenty years, however, suggests otherwise. To be sure, Congress did not reject President Nixon's proposed reorganization. ${ }^{3}$ Congress acquiesced, and EPA commenced operations on December 2, 1970, amidst much fanfare and congressional good wishes. EPA's tenure has nonetheless been marked by the very type of crisis and controversy just described. What should seem to be unlikely combinations of institutional forces have in fact seriously frustrated from the outset the agency's development and implementation of federal environmental protection policy.

Congress has repeatedly demanded that the agency perform impossible tasks under unrealistic deadlines. ${ }^{4}$ Courts have rejected many of the agency's efforts to provide itself with more leeway in their implementation, while the White House, OMB, and congressional appropriation committees have simultaneously resisted subsequent agency efforts to comply with strict judicial mandates. 5 The agency spends much of its limited resources defending its decisions in court, negotiating with $\mathrm{OMB}$ and the White House, and justifying its decisions to multiple congressional committees. ${ }^{6}$ A virtual

3. President Nixon announced Reorganization Plan No 3 of 1970 pursuant to the Reorganization Act of 1949, then codified at 5 USC $\S \S 901-913$ (1970), which authorized the president to propose reorganization of the executive branch to promote better execution of the laws. Pursuant to that statute, a proposed reorganization was effective unless either chamber adopted a disapproving resolution within sixty days of the president's transmittal of the proposal to Congress. See 5 USC $\S 906(1970)$. There was some sentiment in the House in favor of disapproval, but a resolution to that effect was rejected. See H Res 1209, 91 st Cong, 2d Sess 1 (1970), in 116 Cong Rec $33871-76,33879.84$ (Sept 28, 1970). There was no floor vote in the Senate.

4. See text accompanying notes $46-93$.

5. See text accompanying notes 156-60, 170-74.

6. See text accompanying notes 277-300. 
state of siege and a crisis mentality have persisted at the agency for much of its existence as Congress has responded to each EPA failure by passing even more restrictive deadline legislation that the agency again fails to meet. ${ }^{7}$

In short, a pathological cycle has emerged: agency distrust has begotten failure, breeding further distrust and further failure. The destructive cycle is not simply a product of personality or partisan politics. Replacing Anne Gorsuch with William Ruckelshaus as EPA administrator averted agency collapse in 1983 but did not eliminate the pattern. Nor, at an earlier time, did the coupling of a Democratic president (Carter) with Democratic majorities in both congressional chambers yield fundamental change. ${ }^{8}$

The cycle results from the way in which our governmental institutions have responded to persistent public schizophrenia concerning environmental protection policy. Public aspirations for environmental quality are relatively uniform and strongly held. But those aspirations contrast sharply with the public's understanding of their implications and its demonstrated unwillingness to take the steps necessary to have those aspirations realized. There is an appearance of harmony underlain by much actual disharmony.

Our governmental institutions have exacerbated rather than redressed the discrepancy. These institutions are founded on deep-seated skepticism of those who wield governmental authority, and they seek, through the checks and balances embraced by our tripartite system, to curb potential governmental overreaching and any branch's abuse of the public trust. In the case of EPA, the illusion of harmony suggested agency abuse of its public trust as public aspirations have gone unrealized. At the same time, the various interests that are in disharmony have exploited to their own advantage the institutional forces of distrust within the government to guard against adverse EPA actions. The upshot has been a pattern of agency crisis and controversy and, as described, a cycle of regulatory failure.

The cycle must now be reversed. The need to reduce dramatically the strain we place on the natural environment is simultaneously immediate and long-term. Our domestic laws reflect that understanding and express a symbolic commitment to that goal. Those laws have achieved, moreover, significant improvement in discrete areas and, in some others, have managed to resist further environmental degradation in the face of a growing economy. ${ }^{9}$ For that reason, they warrant great praise. The past twenty years nevertheless reveal that those same laws decline to undertake the concomitant modification of our governmental institutions, and the way we think about them, which is necessary for a fuller realization of our environmental goals. EPA's 20th anniversary and expected elevation to cabinet status as the Department of the Environment provide an appropriate occasion to initiate a

7. See text accompanying notes 185-234.

8. See R. Shep Melnick, Regulation and the Courts: The Case of the Clean Air Act 33-35 (Brookings Inst, 1983). Nor, for that matter, did the combination of a Republican administration and a Republican-controlled Senate from 1980 to 1986 eliminate the tension.

9. See Council on Environmental Quality, Seventeenth Annual Report 17 (U.S. Govt Printing Office, 1986) (describing significant advances in environmental quality since 1970). 
much needed institutional study of the federal environmental protection effort, which is the purpose of this article. A retrospective on EPA illustrates the causes and effects of the cycle of distrust that has plagued the agency since its inception. More importantly, the inquiry lays the foundation for a more positive discussion of how to avoid repeating the cycle and how instead to facilitate the type of social and institutional innovation necessary for protection of the natural environment.

II

The Origins of EPA and Its Early Years: Agency Capture and the Seeds of Distrust

Historically, the creation of EPA in 1970 was a modest step in the wake of decades of debate concerning how best to institutionalize natural resource planning and environmental protection within the federal government. ${ }^{10}$ President Nixon ultimately rejected the recommendation of his Advisory Council on Executive Branch Reorganization-the "Ash Council" headed by Roy Ash-that he establish a cabinet level Department of Environment and Natural Resources. ${ }^{1}$ The Ash Report called for a consolidation into one agency of most of the natural resource and pollution control programs then located in forty-four bureaus and offices within nine different agencies, including the Army Corps of Engineers, Soil Conservation Service, Forest Service, and Rural Electrification Administration. ${ }^{12}$ Congress likewise shelved parallel suggestions that it too should foster systematic and coordinated federal environmental and natural resource policy planning by reducing the fragmentation of authority over that subject matter then reflected in its committee structure. Congress took no such action, ${ }^{13}$ and President Nixon ultimately proposed only the creation of a noncabinet-level federal agency

10. See Lynton K. Caldwell, Environment: A Challenge to Modern Society 197-225 (Natural History Press, 1970); Charles O. Jones, Clean Air: The Policies and Politics of Pollution Control 54-71 (U Pittsburgh Press, 1975).

11. Detailed accounts of the debates leading to the creation of EPA can be found in J. Clarence Davies, III \& Barbara S. Davies, The Politics of Pollution 103-20 (Bobbs-Merrill, 2d ed 1975); Alfred A. Marcus, Promise and Performance: Choosing and Implementing an Environmental Policy 32-47 (Greenwood Press, 1980); John C. Whitaker, Striking A Balance 54-60 (Am Inst Public Policy Res, 1976). See also Department of Environmental Protection Act, Committee of the Whole House on the State of the Union, HR Rep No 101-428, 10 lst Cong, 2d Sess 19-20 (1990); Paul R. Portney, ed, Public Policies for Environmental Protection 9-11 (Resources for the Future, 1990). The Ash Council staff originally recommended to Roy Ash, its chair, a separate noncabinet-level agency concerned with pollution control, but was overruled by Ash. Ash then promoted adoption of a plan under which the number of cabinet agencies would be decreased to four super departments (community development, economic affairs, human resources, and natural resources). He was concerned that a separate pollution control agency would undermine his general plan. See Davies \& Davies, The Politics of Pollution at 107-08 (cited earlier in this note); Marcus, Promise and Performance at 37-38 (cited earlier in this note). The Ash Council did ultimately recommend the creation of a comprehensive "Department of Natural Resources" that consolidated in that new agency the principal natural resources programs of the executive branch. See generally President's Advisory Council on Executive Organization, Memorandum for the President on the Establishment of a Department of Natural Resources (May 12, 1970).

12. Whitaker, Striking a Balance at 54-55 (cited in note 11).

13. See notes $37-38,353$ and accompanying text. 
that consolidated the federal pollution standard setting functions then located in fifteen offices within four agencies and one interagency council. ${ }^{14}$ The reorganization transferred to EPA only nine of approximately fifty federal programs then pertaining to the environment. ${ }^{15}$

A major reason why both President Nixon. and Congress took relatively modest action in institutionalizing a federal role for environmental protection also explains much of EPA's subsequent history. It underlies the subsequent whipsawing of EPA within and among the executive, legislative, and judicial branches over the last twenty years, and it finds its ultimate expression in the pathological cycle of regulatory failure and controversy that has plagued the agency from the outset.

Simply put, EPA was not trusted. Myriad interest groups were potentially affected by a federal agency responsible for environmental protection. Some favored the agency's establishment and its mandate; many others, however, were threatened by both. All recognized that the agency would face tremendous pressures in its effort to fashion and implement federal environmental protection laws. Each therefore sought to prevent "agency capture," meaning EPA's domination by an adverse competing interest.

In particular, three variants of agency capture theory have predominated and strongly influenced EPA's institutional development. The first hypothesis, identified with the works of Professor Marver Bernstein, ${ }^{16}$ concerns the tendency of administrative agencies to ally themselves, over time, with the community they regulate. At the time of EPA's creation, Ralph Nader's organization had published a series of books, relying on Bernstein's thesis, that accused various federal agencies (including the Department of Agriculture's pesticides program) of being in a state of agency capture. ${ }^{17}$

14. EPA inherited 5,743 employees from 15 agencies, including the (1) Federal Water Quality Administration (Interior); (2) Bureau of Water Hygiene (Health, Education and Welfare ("HEW")); (3) National Air Pollution Control Administration (HEW); (4) Bureau of Solid Waste Management (HEW); (5) Bureau of Radiological Health (with exceptions) (HEW); (6) functions relating to the establishment of tolerances for pesticide chemicals (HEW); (7) functions relating to the provision of technical assistance to the states and to conduct research regarding pesticide chemicals $(\mathrm{HEW}) ;(8)$ Pesticides Regulation Division (Agriculture); (9) functions under 21 USC $\$ 346(\mathrm{a})$ (1) of the Federal Food, Drug, and Cosmetic Act (Agriculture); (10) Environmental Quality Branch of the Plant Protection Division of the Agricultural Research Service (Agriculture); (11) functions relating to studies on effects of pesticides on wildlife and fish (Interior); (12) functions of the Gulf Breeze Biclogical Laboratory of the Bureau of Commercial Fisheries (Interior); (13) Federal Radiation Council (interagency council); (14) Division of Radiation Protection Standards (Atomic Energy Commission); and (15) functions of the Council on Environmental Quality under 42 USC $\$ 4344(5)$ of the National Environmental Policy Act of 1969 (42 USC $\$ \S 4321$ et seq (1988)). Reorganization Plan No $3 \S 2$ (cited in note 2). See Joseph L. Bower \& Charles J. Christenson, Public Management: Text and Cases 100-03 (Irwin, 1978).

15. Reorganization Plan No 3 of 1970. Hearings before the Subcommittee on Executive and Legislative Reorganization of the House Committee on Govt Operations, 91st Cong, 2d Sess 57 (1970) (statement of Rep. Blatnik and testimony of Mr. Ash).

16. See, for example, Marver Bernstein, Regulating Business by Independent Commission 79-94 (Princeton U Press, 1955). See also James Q. Wilson, Bureaucracy: What Govemment Agencies Do and Why They Do It 73-74 (Basic Books, 1990); Richard B. Stewart, The Reformation of American Administrative Law, 88 Harv L. Rev 1667, $1685-86$ (1975).

17. See generally Robert C. Fellmeth, Edward F. Cox \& John E. Schulz, The Vader Report on the Federal Trade Commission (R.W. Baron. 1969); James S. Turner, The Chemical Feast: The Ralph Nader 
The second thesis, most thoughtfully articulated by Professor Joseph Sax, concerns the tendency of agency personnel to bargain away environmental values as part of the political process. ${ }^{18}$ According to Sax, agency officials are simply incapable of providing natural resources with long-term protection from persistent and influential economic interests. ${ }^{19}$ The constant demands on the bureaucracy for compromise are too great. ${ }^{20}$

Finally, there are those who fear the agency's capture by its own bureaucracy. ${ }^{21}$ Unlike the other two theories, the primary proponents of this view are concerned with the agency paying too little attention to the needs of the regulated. The theory is premised on the reputedly liberal, proregulatory bias of the federal bureaucracy, particularly that in an agency rearrangement such as EPA with a social mission. ${ }^{22}$

EPA's creation and the manner in which it was initially received within the executive branch, by Congress, and the courts can largely be traced to these three different capture theories. These theories affected EPA's organization within the executive branch, its internal structure, the structure and focus of the federal environmental laws under its jurisdiction, and the amount and character of judicial review of its actions.

\section{A. Executive Branch}

Within the Executive Office of the President and Cabinet in 1970, there were two competing philosophies regarding environmental regulation. Those sympathetic to an active federal pollution control program were opposed to its inclusion in a cabinet agency along with the government's traditional natural resource management programs. The historically pro-development

Study Group Report on Food Protection and the FDA (Grossman, 1970); Robert C. Fellmeth, The Interstate Commerce Commission: The Ralph Nader Study Group Report on the Interstate Commerce Commission and Transportation (Grossman, 1970); John C. Esposito, Vanishing Air: The Ralph Nader Study Group Report on Air Pollution (Grossman, 1970); David Zwick, Water Wasteland: The Ralph Nader Study Group Report on Water Pollution (Grossman, 1971). See also Michael Frome, The Forest Service (Praeger, 1971).

18. See generally Joseph L. Sax, Defending the Environment (Knopf, 1970).

19. Id at $53-55,88-89$.

20. Id at $\mathbf{5 5}$.

21. President Nixon reportedly was concerned generally with liberals in the bureaucracy undermining his agenda. See Wilson, Bureaucracy at 50, 76 (cited in note 16). Others in the White House have since frequently harbored suspicions that EPA career employees have conspired with environmental organizations against the administration. See Melnick, Regulation and the Courts at 115 (cited in note 8). The Reagan White House exhibited similar concerns. See J. Clarence Davies, Environmental Institutions and the Reagan Administration, in Norman J. Vig \& Michael E. Kraft, eds, Environmental Policy in the 1980s: Reagan's New Agenda 144 (Cong Q, 1984); Christopher Harris, William L. Want \& Morris A. Ward, Hazardous Waste-Confronting the Challenge 30-31 (Quorem, 1987). Some political appointees allegedly prepared hit lists to rid the agency of its liberal influence. See Donald V. Feliciano, The United States Environmental Protection Agency: An Analysis of Its Controversies 44 (Cong Res Serv, 1983) ("EPA: An Analysis of Its Controversies"). The Bush Administration has not been immune from harboring similar suspicions toward EPA's bureaucracy. See Maureen Dowd, Sununu on Environment: His Influence is Debated, NY Times Al col 1 (Feb 15, 1990). President Bush's Chief of Staff, John Sununu, explained that he helps to formulate environmental policy because of his "deep distrust of the EPA bureaucrats "who forget that it is Bill Reilly and the President who make policy." Id at Al4 col 4 . Unnamed White House officials reportedly believe that "Reilly has been captured by his bureaucracy." Id at A14 col 1.

22. Wilson, Bureaucracy at 65-66 (cited in note 16). 
bias of those natural resource programs, it was feared, would dominate the agency and undermine pollution control efforts. ${ }^{23}$ Conversely, those in the executive branch, including President Nixon, who were concerned about the possible adverse economic impact of environmental protection on existing federal programs, sought to limit the new agency's jurisdiction and maintain presidential control over the agency's decisions. ${ }^{24}$

The final presidential proposal reflected a compromise of these forces. The agency was independent in the sense that it was placed outside the formal jurisdiction of any other agency, but unlike a truly independent agency, its administrator and assistant administrators were to serve at the President's pleasure and formally report to the President through OMB. ${ }^{25}$ The agency's pollution control jurisdiction was not combined with any of the federal government's natural resource management authority, but neither was the pollution control dimension of that management authority surrendered to the new agency. For instance, the President did not transfer to EPA all of the Department of Agriculture's jurisdiction over pesticide regulation. The Army Corps of Engineers also retained jurisdiction to regulate certain types of environmentally harmful activities occurring within the nation's traditional navigable waters.

In addition, at the same time that the President proposed the creation of EPA, he counterbalanced it with the creation of the National Oceanic and Atmospheric Administration ("NOAA") and National Industrial Pollution Control Council ("NIPCC") within the Department of Commerce. ${ }^{26}$ Commerce's pro-business perspective, the President believed, would minimize the chance of NOAA impeding economic activity within the coastal zone. NIPCC was made up of senior officials of major domestic corporations and trade associations and was designed to provide an authoritative source within the government on the adverse economic impact of pollution control. ${ }^{27}$ Working with OMB, NIPCC was intended to provide the President with an institutional mechanism for maintaining control over EPA. ${ }^{28}$

Finally, the internal structure of EPA reflected competing agency capture concerns. The Ash Council contemplated that, like the Defense Department,

23. See Davies \& Davies, The Politics of Pollution at 108 (cited in note 11); Marcus, Promise and Performance at 35 (cited in note 11 ).

24. Marcus, Promise and Performance at 41 (cited in note 11 ).

25. Sheldon M. Novick, Donald W. Stever \& Margaret G. Mellon, eds, Law of Environmental Protection \$ 4.01(1) (Clark-Boardman, 1990).

26. See Reorganization Plan No 4 of 1970, 5 USC Reorg Plan of 1970 No 4, App (1988) (proposing NOAA); Environmental Protection Agency and National Oceanic Atmospheric Administration, The President's Message to the Congress upon Transmitting Reorganization Plans to Establish the Two Agencies, 35 CFR 5993 (April 9, 1970) (establishing NIPCC). Note that NIPCC was officially disbanded on January 5, 1975 under the provisions of Pub L No 92-463, 86 Stat 770 .

27. See Statement on Establishing the National Industrial Pollution Control Council, April 9, 1970, 6 Weekly Comp Pres Docs 502 (April 13, 1970). See generally Henry J. Steck, Private Influence on Environmental Policy: The Case of the National Industrial Pollution Control Council, 5 Envir L 241, 253-59 (1975); Whitaker, Striking a Balance at 40 (cited in note 11).

28. Steck, 5 Envir $\mathrm{L}$ at 259-79 (cited in note 27). Congress, however, retaliated against the NIPCC by declining in 1973 to appropriate any staff funds for fiscal year 1974. See id at 280 . In January 1975, the Commerce Department formally terminated the council. Id at 279. 
EPA would be organized by function (for example, by abatement, monitoring, enforcement, standard setting, and research). ${ }^{29}$ Such a structure would allow the agency to approach the environment as an interrelated system, as suggested by the President in his message transmitting the reorganization plan to Congress, rather than as a series of discrete media (for example, air, water, and land) ${ }^{30}$ There were many perceived advantages to a cross-media approach, including avoidance of the tendency of media-specific programs to ignore their impact on other media. ${ }^{31}$

EPA's first administrator, William Ruckelshaus, however, never fully adopted the contemplated functional, integrated organization. He was not persuaded of the importance of organization in the first instance, and he anticipated objections from members of Congress and the environmental community who, because they were themselves organized by media, would be concerned about the adverse impact of such an organizational scheme on their respective abilities to influence agency policy. ${ }^{32}$ The final agency structure was a compromise that still persists today under which EPA is simultaneously organized both by media and by function.

\section{B. Congress}

EPA's initial reception in Congress reflects the same tension between different philosophies and agency capture theories. There were those in Congress concerned about EPA's possible capture by the regulated community and about the bureaucratic tendency to give in to the political forces that can be wielded in the executive branch by powerful economic interests opposed to expensive pollution control measures. ${ }^{33}$ There were also members of Congress concerned about the dangers of a runaway bureaucracy imposing excessive costs on the nation's economy. ${ }^{34}$

In hearings on the nominations of EPA officials, members of Congress repeatedly questioned presidential appointees about their willingness to exercise judgment independent of the President. ${ }^{35}$ They also reminded

29. Marcus, Promise and Performance at $102-03$ (cited in note 11).

30. Message of the President Relative to Reorganization Plan No 3, July 9, 1970, 6 Weekly Comp Pres Docs 908 (July 13, 1970).

31. Id ("Control of the air pollution may produce more solid wastes, which then pollute the land or water. Control of the water-polluting effluent may convert it into solid wastes, which must be disposed of on land.").

32. Marcus, Promise and Performance at 103-06 (cited in note 11); Marc K. Landy, Marc J. Roberts \& Stephen R. Thomas, The Environmental Protection Agency: Asking the Wrong Questions 35 (Oxford U Press, 1990) ("EPA: Asking the Wrong Questions").

33. See Landy, Roberts \& Thomas, EPA: Asking the IVrong Questions at 33-34 (cited in note 32).

34. Davies \& Davies. The Politics of Pollution at 73-74 (cited in note 11). See notes 165, 171-74 and accompanying text.

35. See, for example, Nomination of William D. Ruckelshaus, Hearings before the Senate Committee on Public Works, 91 st Cong, 2d Sess 15-16 (1970); Nomination of Russell E. Train, Hearing before the Senate Committee on Public Works, 93rd Cong, 1st Sess 7-8 (1973); Nominations of Anne M. Gorsuch and John W. Hernandez, Jr., Hearings before the Senate Committee on Environment and Public Works, 97th Cong, Ist Sess 36-37 (1981); Nomination of William K. Reilly, Hearing before the Senate Committee on Environment and Public Works, $101 \mathrm{st}$ Cong, Ist Sess 50-52 (1989). See generally Stanley Bach, Governmental Constraints in Environmental 
nominees about the need for consultation with congressional committees prior to the agency making any significant decisions. ${ }^{36}$

Congressional committees dominated by those favoring a strong federal pollution control effort secured passage of statutes specifically designed to minimize the possibility of bureaucratic neglect and compromise and of agency capture by regulated industry. ${ }^{37}$ Those in Congress who were more wary of the economic costs of pollution control also sought to oversee and influence EPA's work. Neither side favored consolidation of environmental jurisdiction in a few committees. Each wanted to avoid any reduction in leverage over the agency that might result from any loss of committee jurisdiction. As a result, there was great resistance to many of the early efforts to achieve a congressional reorganization of environmental jurisdiction that was similar to that which was occurring within the executive branch. ${ }^{38}$

Regulation, in Natl Res Council, ed, 2b Decisionmaking at the Environmental Protection Agency: Selected Working Papers 181 (Natl Acad Sciences, 1977) ("some Congressional staff members argue that Congress has delegated regulatory functions to EPA which are to be carried out without presidential influence or interference"). In Administrator Train's hearing, however, he was also sharply questioned by Senator William Scott who was upset by Train's earlier intimation that EPA would be free "to defy the White House." See Nomination of Russell E. Train at 52-55 (cited earlier in this note).

36. See, for example, Nomination of Russell E. Train at 47 (cited in note 35) (Randolph advice to Train); Christopher H. Foreman, Signals From the Hill 83 (Yale U Press, 1988) (Muskie advice to Train); Melnick, Regulation and the Courts at 32 (cited in note 8) (Muskie advice to Ruckelshaus). At least in EPA's early years, EPA reportedly did consult substantially with congressional committees in its decisionmaking. See Bach, Governmental Constraints at 188-92 (cited in note 35).

37. Gary C. Bryner, Bureaucratic Discretion: Law and Policy in Federal Regulatory Agencies 94-108 (Pergamon, 1987). See Howard Latin, Ideal Versus Real Regulatory Efficiency: Implementation of Uniform Standards and "Fine Tuning" Regulatory Reforms, 37 Stan L Rev 1267, 1271 (1985); Edmund S. Muskie. Reflections on a Quarter Century of Environmental Activism: On Postponing Deadlines, Second-Guessing the Congress, and Ignoring Problems Until It Is Too Late, 18 Envir L Rptr 10081, 10082-83 (March 1988); David Schoenbrod, Goals Statutes or Rules Statutes: The Case of the Clean Air Act, 30 UCLA L Rev 740 , 742-45 (1983); Richard B. Stewart, Regulation, Innovation, and Administrative Law: A Concepiual Framework, 69 Cal L Rev 1259, 1265 (1981). See also Wilson, Bureaucracy at 7 I (cited in note 16).

38. The National Academy of Sciences in January 1970 issued a report that suggested the need for both executive and congressional reorganization for effective federal governmental management of the environment. See Institutions for Effective Management of the Environment, Report of the Environmental Study Group to the Environmental Studies Board of the National Academy of Sciences and National Academy of Engineering Part 1, 52 (Jan 1970). There were some initial efforts made to coordinate environmental jurisdiction (see Environmental Policy Division of the Congressional Research Service, Library of Congress, Congress and the Nation's Environment, Environmental and Natural Resources Affairs of the 92d Congress, Senate Committee on Interior and Insular Affairs, 93d Cong, 1st Sess 833-36 (1973) (“Environmental Policy Division"); Report of the Council on Environmental Quality, Hearings before the Subcommittee on Air and Water Pollution of the Senate Committee on Public Works, 9 lst Cong, 2d Sess 2 (1970) (statement of Sen. Muskie); House Hearings on Reorganization Plan No 3 at 118 (cited in note 15) (statement of Rep Dingell)), and some modest reorganization in the Senate years later (see note 355 ), but efforts to consolidate jurisdiction in the House have met with little success. See Henry C. Kenski \& Margaret Corgan Kenski, Congress Against the President: The Struggle Over the Environment, in Vig \& Kraft, Environmental Policy in the 1980s at 110 (cited in note 21). 


\section{Courts}

Finally, the initial relationship between EPA and the courts was likewise heavily influenced by various forms of the capture theory. ${ }^{39}$ As summarized by one commentator, the courts' opinions reflected two different views of the agency. Some courts viewed the agency's work as the product of an overzealous bureaucracy that acted without proper regard for economic concerns; others "pictured the EPA as a marginally competent but occasionally careless agency that from time to time needs to be reminded of the importance of its statutory goals and warned against bowing to demands from the White House and industry."40 The effect was the spawning of the so-called "hard look" doctrine and modern administrative law of the 1970s, much of which was fashioned in the context of environmental litigation. ${ }^{4}$

\section{III}

\section{The Collision of Institutional Forces: The Breeding of Regulatory Failure and Controversy}

The tug-of-war in which EPA found itself might have turned out to be nothing more than a benign, even healthy, application of the checks and balances necessary to realize this country's commitment to the separation of powers. After all, where important regulatory authority is at stake, the various branches will invariably vie for influence in fashioning national policy. It should be no great surprise, moreover, that those institutions should do so at the behest of an interest group seeking to avoid the domination of the regulatory process by an adverse and competing interest.

In the case of EPA, however, the effect has been neither benign nor healthy. The institutional forces set into motion by the various capture theories have repeatedly collided, breeding conflict, controversy, and ultimately a destructive pattern of regulatory failure. No one individual or institution is to blame for this phenomenon. ${ }^{2}$ Indeed, "blame" is an inappropriate characterization. Many of the problems that have arisen in the implementation of environmental law were likely the inevitable result of such a dramatic infusion of new values and priorities into the nation's laws. But, be that as it may, it is possible to understand why this phenomenon resulted and how the cycle may now finally be reversed as we move into the $1990 \mathrm{~s}$.

Most simply put, the forces designed to prevent EPA's capture became pathologically destructive because the country's spiritual environmental

39. Robert Glicksman \& Christopher H. Schroeder, EPA and the Courts: Twenty Years Of Law and Politics, 54 L \& Contemp Probs 249 (Autumn 1991).

40. Melnick, Regulation and the Courts at 371 (cited in note 8).

41. Glicksman \& Schroeder, 54 L. \& Contemp Probs at 267-68 (cited in note 39): Harold Leventhal, Environmental Decisionmaking and the Role of the Courts, $122 \mathrm{U}$ Pa L Rev 509, 514 (1974); James L. Oakes, The Judicial Role in Environmental Law, 52 NYU L Rev 498, 499 (1977); William H. Rodgers, Jr., Environmental Law $\$ 1.5,16-23$ (West, 1977); Stewart, 69 Cal L Rev at 1274-77 (cited in note 37 ).

42. Some former EPA officials, however, have suggested that Congress should be blamed. See John Quarles, Runaway Regulation? Blame Congress, Washington Post B8 col 1 (May 20, 1979). 
awakening in the 1970 s occurred without much of an intellectual understanding of its implications. A strong national consensus in favor of environmental protection prompted the President to create EPA, Congress to pass sweeping environmental laws, and courts to open their doors to environmental plaintiffs. But both the public and those institutions were remarkably unsophisticated about the demands that they were placing upon themselves.

There was little, if any, sense of the huge short-term costs associated with treating pollution as a cost of doing business. Nor was there much awareness of the degree to which settled expectations and lifestyles could be disrupted if the natural environment were to be treated as more than an economic commodity. The public and governmental institutions likewise did not truly appreciate the incalculable nature of the benefits of environmental protection, including the scientific uncertainty associated with the measurement of those benefits and the long term intergenerational nature of their realization. There was especially little apprehension of how those characteristics would challenge the patience of both those sympathetic to, and those skeptical of, the new federal programs.

Nor were the late 1960 s and early 1970s a time susceptible to the type of candid dialogue between citizen groups and business, Congress and the President, or scientists and economists that would have been required to begin to reach consensus on these issues. ${ }^{43}$ The civil rights and antiwar movements had polarized the nation. In the aftermath of powerful denunciations of the chemical and auto industries and government by activists Rachel Carson (Silent Spring (1962)) and Ralph Nader (Unsafe at Any Speed (1965)), the credibility of government and business on health and safety issues was exceedingly low. ${ }^{44}$ Indeed, because of the civil rights and antiwar movements, there was a pressing need for national consensus on some important issue. That need satisfied itself by embracing the environmental movement. The social consensus behind the environmental movement was illusory, however, and as the conflicts became apparent, EPA, which was the object of the country's hopes and dreams about the environment, often became the object of its frustration and scorn. ${ }^{45}$

43. John McCormick, Reclaiming Paradise 69-87 (Indiana U Press, 1989) (describing the "prophets of doom" behind the environmental movement of the late 1960s and early 1970s).

44. See, for example, Billee Shoecraft, Sue the Bastards vii-x, xxi-xxiii, 446-51 (1971); Victor John Yannacone, Jr., Courts of Equity to Protect Our Environment, in Proceedings, 63rd Annual Convention of the National Audubon Society (Sept 30, 1967), excerpted in Victor John Yannacone, Jr., The Environment and the Law, 9 Forum 795, 797-98 (1974).

45. Professor Louis Jaffe long ago predicted this chain of events. See Louis L. Jaffe, Two Days to Save the World, 24 Okla L Rev 17 (1971). See also James O. Freedman, Crisis and Legitimacy: The Administrative Process and American Covernment 264 (Cambridge U Press, 1978) (arguing that the limits of administrative process generally coincide with "the bounds of the social consensus on the agency's statutory responsibilities" and "when society does not respect these limits . . it condemns agencies to undertake tasks beyond their institutional capacity to perform effectively"). 
A. The Breeding of Regulatory Failure

Congress responded to the perception of a national consensus in environmental protection by passing a series of laws in the 1970s that set the stage for institutional conflict and agency failure. Congress lacked the incentive to address or emphasize the pitfalls and chose instead to join the chorus in favor of immediate and fundamental change. ${ }^{46}$ The congressional votes in favor of the new laws were accordingly overwhelmingly favorable. The average vote in favor of major federal environmental legislation during the 1970 s was seventy-six to five in the Senate and 331 to thirty in the House. ${ }^{47}$ As one legislator put it in describing his reluctant vote in favor of safe drinking water legislation in 1974, "[a]fter all, if one votes against safe drinking water, it is like voting against home and mother." 48

1. From Public Aspiration to Statutory Mandate. The federal environmental statutes of the early 1970s were dramatic, sweeping, and uncompromising, consistent with the nation's spiritual and moral resolution of the issue. The laws also reflected skepticism and distrust of agency implementation of statutory mandates, consistent with agency capture theory and the general political ill will then existing between the executive and legislative branches. The statutes imposed hundreds of stringent deadlines on the agency and removed much of the agency's substantive discretion in accomplishing them. One-third of the deadlines were for six months or less. ${ }^{49}$ Sixty percent were for one year or less. ${ }^{50}$ According to EPA's current administrator, William Reilly, Congress and the courts had imposed 800 deadlines on the agency through 1989.51 Congress made no effort to bridge the gap between the nation's aspirations for environmental protection and its understanding of the underlying issues and its own capacity for change.

The result was a seemingly never-ending onslaught of impossible agency tasks. Eighty-six percent of the statutory deadlines applied specifically to

46. John P. Dwyer, The Pathology of Symbolic Legislation, 17 Ecol L Q 233 (1990).

47. These numbers are based on the last recorded roll call vote taken in each chamber for each of the major bills ultimately passed by Congress in the 1970s. In most cases, the final votes were voice votes. The statutes covered include the Clean Air Act of 1970 ("CAA"), the Federal Water Pollution Control Act ("FWPCA"), the 1977 Clean Air Act, the 1977 Clean Water Act ("CWA"), the Federal Insecticide, Fungicide and Rodenticide Act ("FIFRA"), the Resource Conservation and Recovery Act ("RCRA"), and the Toxic Substances Control Act ("TSCA"). The numbers do not reflect the votes in favor of the Safe Drinking Water Act ("SDWA") in 1974 because there docs not appear ever to have been a recorded roll call vote in the Senate. The formal votes are not, of course, an accurate measure of congressional support for every aspect of the bills passed. Many parts of those bills were likely quite contentious and, if added by amendment during debate, might well have been adopted by the narrowest of margins. The final votes are more lopsided because each legislator is faced with an all or nothing choice.

48. 120 Cong Rec 37594 (Nov 26, 1974) (remarks of Sen. Cotton).

49. Statutory Deadlines In Environmental Legislation: Necessary But Need Improvement 13-14 (Envir \& Energy Study Inst and Envir L Inst, 1985) ("EESI, Statutory Deadlines").

50. Id.

51. See William K. Reilly, The Tuming Point: An Environmental Vision for the 1990s (Marshall Lecture at the Natural Resources Defense Council, Nov 27, 1989), reprinted in 20 Envir Rptr Curr Dev (BNA) 1386, 1389 (Dec 8, 1989). 
EPA.52 EPA was "told to eliminate water pollution, and all risk from air pollution, prevent hazardous waste from reaching ground water, establish standards for all toxic drinking water contaminants, and register all pesticides."53 To date, EPA has met only about 14 percent of the congressional deadlines imposed and has had 80 to 85 percent of its major regulations challenged in court. ${ }^{54}$

a. Air Pollution. In the Clean Air Act Amendments of $1970,{ }^{55}$ Congress mandated the achievement by 1975 of national ambient air quality standards ("NAAQS") necessary for the protection of public health (primary standard) and public welfare (secondary standard). ${ }^{56}$ Congress also instructed EPA to publish an initial listing of "hazardous" air pollutants within ninety days and then, within 180 days of its listing, to publish for each such pollutant a proposed "emission standard" for the protection of public health. ${ }^{57}$ The deadline for final emission standard regulations was 180 days later. ${ }^{58}$ Congress established a similarly rigid schedule for EPA's listing of categories of stationary sources that "may contribute significantly to air pollution which causes or contributes to the endangerment of public health or welfare" (ninety days), and an even tighter schedule for promulgation of regulations for new sources (120 days after inclusion as a secondary source for proposal; ninety days after proposal for final promulgation). ${ }^{59}$ The Clean Air Act also mandated that the administrator achieve a $\mathbf{9 0}$ percent reduction in existing automotive pollutant levels by 1975 (hydrocarbons and carbon monoxide) and 1976 (nitrogen oxides), with a narrow provision for a possible one-year extension. ${ }^{60}$

The administrative task was enormous. It required strict regulation of 20,000 to 40,000 major stationary sources of air pollution, millions of cars

52. EESI, Statutory Deadlines at 11 (cited in note 49 ). The remaining $14 \%$ was evenly divided between the regulated community (including public water supply companies) and the states. Id.

53. Council on Environmental Quality, Sixteenth Annual Report 14 (U.S. Govt Printing Office, 1985) ("CEQ Sixteenth Annual Report").

54. EESI, Statutory Deadlines at ii, 12 (cited in note 49) (14\% compliance refers to all environmental statutory deadlines, $86 \%$ of which apply to EPA); Bryner, Bureaucratic Discretion at 117 (cited in note 37$)$ ( $80 \%$ of EPA's major regulations challenged in court). See CEQ Sixteenth Annual Report at 2-3 (cited in note 53) ("Fully 85 percent of EPA's regulations result in litigation.").

55. Pub L No 91-604, 84 Stat 1676 (1970), then codified at 42 USC $\S \S 1857$ et seq (1970). Apart from scattered minor revisions, Congress has amended the Clean Air Act twice: in 1977 (Pub L No 95-95, 91 Stat 685 (1977)) and 1990 (Pub L No 101-549, 104 Stat 2391 (1990)). The 1977 amendments also called for a recodification of the entire Act, now found at 42 USC $\$$ 7401-7642 (1988).

56. Congress authorized EPA to extend for up to two years the 1975 deadline for compliance with the primary standard. Congress also authorized EPA to extend the deadline for submission of the plans for compliance with the Act's secondary standards. See Clean Air Act Amendments of 1970 , Pub L No 91-604, $\S 109,110,84$ Stat $1679-83$, then codified at 42 USC $\$ \S 1857 \mathrm{c}-4,1857 \mathrm{c}-5$ (1970). See generally James E. Krier \& Edmund Ursin, Pollution and Policy 200-08 (U Cal Press, 1977).

57. Clean Air Act Amendments of 1970, Pub L No 91-604, §§ 112(b)(1)(A)-(B), 84 Stat 1685 , then codified at 42 USC $\$ \S 1857 \mathrm{c}-7(\mathrm{~b})(\mathrm{l})(\mathrm{A})-(\mathrm{B})(1970)$.

58. 42 USC $\$ 1857 \mathrm{c}-7$ (b)(I)(B) (1970).

59. Id \& $1857 \mathrm{c}-6(\mathrm{~b})(1)$.

60. Id $\S 1857 \mathrm{f}-1$. 
and trucks being driven by average citizens, ${ }^{61}$ and 275 toxic air pollutants (sixty of which are known or suspected carcinogens), ${ }^{62}$ many of which were emitted by industries vital to local economies. In short, the Act challenged not only "business as usual" but "life as usual" in the United States and demanded that EPA immediately seek dramatic change in both. The short time scale necessarily precluded prolonged attention to the tremendous scientific uncertainty associated with the complex mechanics of air pollution. It also did not allow for much serious agency consideration of the relative costs and benefits of air pollution reduction. Neither the NAAQS nor the toxic emission standards allowed for any significant consideration of their economic costs.

Not surprisingly, fewer than 15 percent of the Clean Air Act's deadlines were met. None of those met pertained to compliance with environmental quality standards. ${ }^{63}$ Twenty years later, many areas of the nation still have not met the NAAQS. Both EPA and Congress have given the auto companies numerous extensions of the deadline for meeting 90 percent reduction in emissions of hydrocarbons, carbon monoxide, and nitrogen oxides, and, twenty years later, the companies have still not reduced nitrogen oxides by 90 percent. ${ }^{64}$ EPA has acted on only seven of the 274 known hazardous substances emitted into the air. ${ }^{65}$

b. Water Pollution. The Federal Water Pollution Control Act Amendments of 1972 took a similar approach. ${ }^{66}$ The 1972 enactment sought fishable and swimmable waters everywhere by 1983 and zero discharge of pollutants by 1985,67 and it made unlawful any discharge of pollutants into navigable waters absent a permit issued by EPA. The act instructed EPA to require through the permitting process that industry secure the "best practicable control technology currently available" ("BPT") by 1977 and "best available technology economically achievable" ("BAT") by 1984.68

61. Melnick, Regulation and the Courts at 307 (cited in note 8).

62. Clean Air Act Amendments of 1990, Report of the House Committee on Energy and Commerce, HR Rep No 101-490, 101 st Cong, 2d Sess 151-52 (1990).

63. See EESI, Statutory Deadlines at 11-16 (cited in note 49). The 15\% figure reflects the number of Clean Air Act deadlines that EPA had met as of 1985 when the Environmental and Energy Study Institute released its report on statutory deadlines. Because, however, that study necessarily included the Clean Air Act Amendments of 1977, which extended some of the deadlines established in the original $1970 \mathrm{Act}$, the $15 \%$ figure is likely high with regard to EPA's meeting the earlier deadlines.

64. See Frederick R. Anderson, Daniel R. Mandelker \& A. Dan Tarlock, Environmental Protection: Law E' Policy 203-06 (Little, Brown, 1990).

65. HR Rep No 101-490 at 151 (cited in note 62).

66. Pub L No 92-500, 86 Stat 816-903, then codified at 33 USC $\$ \S 1251-1376$ (Supp II 1972). Congress has since enacted scattered revisions of the law but has passed comprehensive amendments on only two subsequent occasions: in 1977 when Congress renamed the law the Clean Water Act (Pub L No 95-217, 91 Stat 1566) and then again in 1987 (Pub L 100-4, 101 Stat 7).

67. Federal Water Pollution Control Act Amendments of 1972, Pub L No 92-500, $\S 101$ (a)(1)(2), 86 Stat 816 , then codified at 33 USC $\$ \S 1251$ (a)(1), (2) (Supp II 1972). See generally Rodgers, Environmental Law $\$ 4.2$, at 361-68 (cited in note 41 ).

68. Pub L No 92-500, 86 Stat 844 , then codified at 33 USC $\S 1311$ (b)(1)(A), (2)(A) (Supp II 1972). 
Section 306 of the Act compelled EPA to require new sources of water pollution to achieve effluent reduction "achievable through the application of the best available demonstrated control technology" ("BDT"). 69 EPA was supposed to promulgate effluent guidelines by October 1973 and permit limitations by December $1974 .^{70}$

The required administrative undertaking was no less daunting than that posed by the Clean Air Act. There are at least 68,000 point sources of water pollution requiring federal permits and probably thousands more. ${ }^{71}$ As one commentator put it, to develop appropriate effluent limits for each of those sources based on BPT, BAT, and BDT technological standards demanded "omniscience."72 The zero discharge goal was plainly impossible and the fishable/swimmable mandate could not, in any event, be met by the strict technology-based effluent reduction requirements of the permit program; the large amount of nonpoint pollution not covered by the Act's permitting program was sufficient, by itself, to prevent EPA's success. ${ }^{73}$ By 1985 , only 18 percent of the deadlines established by federal water pollution legislation had been met. ${ }^{74}$ As with the Clean Air Act, none of the deadlines for compliance with environmental quality standards was met. ${ }^{75}$

c. Pesticides, Toxic Substances, and Hazardous Waste. In the 1972 amendments to the Federal Insecticide, Fungicide, and Rodenticide Act ("FIFRA"), ${ }^{76}$ Congress gave EPA just four years to review approximately 50,000 pesticides that had previously been registered under far more permissive statutory requirements. ${ }^{77}$ For registration, EPA had to determine that the pesticide's intended use would not cause "unreasonable adverse effects on the environment" when used "in accordance with widespread and commonly recognized practice." 78 The 1976 deadline, like others, proved

69. Pub L No 92-500, 86 Stat 854 , then codified at 33 USC $\S 1316$ (Supp II 1972).

70. Id $\S 1316(b)(1)$.

71. EPA had issued this number of permits under the act by October 1982. A. Myrick Freeman, III, Water Pollution Policy, in Portney, ed, Public Policies for Environmental Protection at 112 (cited in note 11). Thousands of facilities discharge into permitted, publicly owned treatment works. See State of the Environment-A View Toward the Nineties 102 (Conservation Foundation, 1987) ("A recent EPA study, for instance, identifies about 160,000 industrial and commercial facilities that discharged wastes containing hazardous constituents to publicly owned treatment works.").

72. Charles L. Schultze, The Public Use of the Private Interest 52 (Brookings Inst, 1977).

73. See John E. Bonine \& Thomas O. McGarity, The Law of Environmental Protection: CasesLegislation-Policies 436-37 (West, 1984). See generally State of the Environment at 104-06 (cited in note $71)$; Daniel R. Mandelker, Controlling Non-Point Source Water Pollution: Can It Be Done, 65 Chi-Kent L Rev 479, 480-82 (1989).

74. EESI, Statutory Deadlines at 12 (cited in note 49 ).

75. Id at 12,15 .

76. Pub L No 92-516, 86 Stat 973-999, then codified at 7 USC $\S \S 136-136 y$ (Supp II 1972).

77. See Note, Pesticide Safety Regulation Under the Federal Insecticide, Fungicide and Rodenticide Act: Debacle at the Environmental Protection Agency, 1 Fordham Envir L J 47, 51 (1989) (authored by John P. Gasior). Unlike the congressional committees that fashioned the other major environmental protection laws of the early and mid-1970s, those who drafted the 1972 FIFRA amendments were not "strongly committed to environmental values." Rodgers, Environmental Lau' $\$ 8.3$, at 849 (cited in note 41 ). As a result, the law's "sometimes contradictory aims compound the usual problems of interpretation." Id at 850 .

78. 7 USC $\S 136 a(c)(5)$ (Supp II 1972). 
impossible. EPA believed that it would take at least ten years to complete the re-registration process, and it has actually taken much longer. ${ }^{79}$ EPA has issued relatively few final re-registrations each year.80 By 1984, EPA had reregistered less than half of the 600 active pesticide ingredients and had not addressed any of the 900 inert ingredients, some of which may be more toxic than the active ingredients. ${ }^{81}$ Before recent changes in the pesticides law, EPA's rate of re-registration suggested that the agency would not complete the re-registration process until $2024 .^{82}$

The Toxic Substances Control Act ("TSCA"), which became law in 1976,83 asked EPA to review approximately 50,000 to 55,000 chemicals then in commerce as well as each of the 1,000 new chemicals introduced each year to determine if they "may present an unreasonable risk of injury to health or the environment." 84 By 1985, EPA had performed the necessary health assessments on fewer than 100 of the chemicals in commerce. ${ }^{85}$

Finally, congressional dictates to EPA regarding the regulation and cleanup of hazardous wastes were no less overwhelming. In the Resource Conservation and Recovery Act of 1976 ("RCRA"), 86 enacted just ten days after TSCA, Congress gave EPA only eighteen months to promulgate regulations regarding the identification, generation, transportation, treatment, storage, and disposal of hazardous wastes. ${ }^{87}$ In the Comprehensive Environmental Response Compensation and Liability Act ("CERCLA"), enacted in 1980,88 Congress authorized EPA to take action to clean up inactive and abandoned hazardous waste sites either by filing lawsuits against those who contributed to the sites to force them to clean up the sites themselves, or by arranging for government cleanup, followed by lawsuits for reimbursement from contributors. ${ }^{89}$

These mandates on hazardous waste control and cleanup may have proved the most difficult to achieve. There are approximately 650,000 generators of hazardous wastes producing 250 million metric tons of such waste each

79. Anderson, Mandelker \& Tarlock, Environmental Protection at 577 (cited in note 64).

80. Id.

81. CEQ Sixteenth Annual Report at 14-15 (cited in note 53). A more recent Washington Post editorial found even less EPA progress in pesticide re-registration. See More Minuet on Pesticides, Washington Post A26 (Nov 2, 1989) ("Of more than 600 active ingredients in older pesticides, EPA has managed in 17 years to complete the reevaluation by modern techniques of fewer than 10.").

82. William H. Rodgers, 3 Environmental Law: Pesticides and Toxic Substances XI (West, 1988).

83. Pub L No 94-469, 90 Stat 2003-2051, codified at 15 USC $\$ \$ 2601-2629$ (1988).

84. See 15 USC $\S 2603(\mathrm{a})(1)(A)$ (1988) (TSCA testing requirements); Steven Cohen, EPA: $A$ Qualified Success, in Sheldon Kamieniecki, Robert O'Brien \& Michael Clarke, eds, Controversies in Environmental Policy 191 (State U NY Press, 1986); Portney, Public Policies for Environmental Protection at 21-22 (cited in note 11 ).

85. CEQ Sixteenth Annual Report at 15 (cited in note 53). See also Portney, Public Policies for Environmental Protection at 21-22 (cited in note 11).

86. Pub L No 94-580, § 2, 90 Stat 2795-2841, then codified at 42 USC $\S \S 6901-6987$ (1976).

87. Id, 90 Stat 2806-2808, then codified at 42 USC $\$$ \$ 6921-6925 (1976).

88. Pub L No $96-510, \S 2,94$ Stat 2767-2811, then codified at 42 USC $\$ \S 9601-9657$ (Supp IV $1980)$.

89. 42 USC $\S 9604-9607$ (1988). 
year. ${ }^{90}$ There are 5,000 facilities authorized to treat, store, or dispose of hazardous waste and approximately 27,000 abandoned hazardous waste sites, 2,000 of which will require federal action. ${ }^{91}$ The Office of Technology Assessment estimates that there are also about 600,000 active or former solid waste disposal facilities, 10,000 of which may require federal action. ${ }^{92}$ EPA did not meet any of the 1978 RCRA deadlines and as of 1989 had completed cleanup at fewer than fifty abandoned sites. ${ }^{93}$

2. The Coalition for Failure. These series of impossible tasks did more than guarantee repeated agency failure; they triggered a chain of events that profoundly influenced EPA's institutional development and the evolution of federal environmental law. Those who supported these statutory mandates sought judicial review and enlisted some in Congress to oversee EPA's implementation. Their aim was to guard against EPA's abdication of its statutory responsibilities. At the same time, those who were opposed to the statutory mandates but who were unable to muster the political capital to defeat their passage, were nonetheless quite successful in enlisting others in Congress, the executive branch, and some courts to impede EPA's implementation of the mandates.

a. Agency Funding. Forces within Congress were able to secure passage of various environmental statutes that reflected the nation's aspirations for environmental quality, but a very different set of institutional forces was responsible for appropriating funds for the implementation of those laws. Members of the appropriations committees typically did not share the environmental zeal of those on the committees who drafted the laws. Indeed, some were quite skeptical of the efficacy of those laws. ${ }^{94}$ The skeptics may have been reluctant to voice publicly their opposition to passage of the statutes-because of the popular appeal of environmental protection-but they felt far more secure in undermining the statutory mandates in a less visible way through the appropriation process. ${ }^{95}$ Such congressional skeptics were joined in their efforts by those in the executive branch, especially in the

90. Roger C. Dower, Hazardous Wastes, in Portney, ed, Public Policies for Environmental Prolection 154-55 (cited in note 11). Until 1984, Congress exempted from EPA's regulation the 130,000 small generators that create between 100 and $1,000 \mathrm{~kg}$ per month of hazardous waste. See id at 165 .

91. Id at 154-57; Council on Environmental Quality, Fifteenth Annual Report 164-65 (U.S. Govt Printing Office, 1984) ("CEQ Fifteenth Annual Report"). The General Accounting Office estimates the number of sites to be between 13,000 and 425,000. Dower, Hazardous Wastes at 157 (cited in note 90).

92. Dower, Hazardous Wastes at 158 (cited in note 90).

93. EESI, Statutory Deadlines at 12 (cited in note 49) (RCRA); Dower, Hazardous Wastes at 177 (cited in note 90 ).

94. See, for example, Agriculture-Environmental and Consumer Protection Appropriations for 1974, Hearings Before a Subcommittee of the House Committee on Appropriations, 93d Cong, Ist Sess Pt 5, 789-90 (1973) (testimony of EPA Administrator William D. Ruckelshaus); see notes 170-74 and accompanying text.

95. James L. Regens \& Robert W. Rycroft, Funding for Environmental Protection: Comparing Congressional and Executive Influences, 26 Social Sci J 289, 299 (1989); Cohen, EPA: A Qualified Success at 181 (cited in note 84 ). 
White House and OMB, who shared their policy outlook and who, accordingly, routinely requested less funding for EPA than Congress ultimately provided. ${ }^{96}$. This coalition for modest EPA funding proved virtually unbeatable.

EPA has consistently received a level of funding far lower than the amount required to provide the agency with even a small chance of moderate success in implementing its statutory mandates. ${ }^{97}$ In constant dollars, the congressional appropriations for EPA were less under President Carter than they were under either Presidents Ford or Nixon. ${ }^{98}$ Between the last EPA budget of President Carter's administration (fiscal year 1981) and President Reagan's EPA budget for fiscal year 1984, EPA's operating budget (excluding Superfund) was reduced 22 percent and its research and development budget was reduced by more than 50 percent. ${ }^{99}$ Even when President Reagan increased the budget under Administrator Ruckelshaus for fiscal year 1985, the increase was less than half of what Ruckelshaus had sought and (in constant dollars) left the agency with 10 percent less than the budget in the last year of the Carter Administration-an amount roughly equivalent to the agency's level of funding ten years earlier. ${ }^{100}$ The trend has not since reversed. There has been a 12 percent decrease in constant dollars in EPA's budget since 1981.101 The number of EPA employees in research and development has fallen from about 2,300 to $1,800 .{ }^{102}$

Of course, during this same period, Congress dramatically increased the scope of EPA's statutory responsibilities. As described above, following the passage of air and water pollution legislation in the early 1970s, Congress added FIFRA to EPA's mandate in 1973, the Safe Drinking Water Act in $1974,{ }^{103}$ and TSCA and RCRA in 1976. Further programmatic expansions were called for by the 1977 Clean Air Act amendments, ${ }^{104}$ the 1977 Clean Water Act, ${ }^{105}$ and CERCLA, passed in 1980. Finally, amendments to RCRA in $1984^{106}$ and to CERCLA in $1986^{107}$ further exacerbated the gap between

96. See Regens \& Rycroft, 26 Soc Sci J at 292-99 (cited in note 95).

97. See Natl Res Council, ed, 2 Decisionmaking in the Environmental Protection Agency 2 (Natl Acad Sciences, 1977) (noting that "EPA's budget and personnel levels continue to fall far short of the demands of the ambitious statutory mandates laid upon the Agency").

98. Regens \& Rycroft, 26 Soc Sci J at 293-94 (cited in note 95).

99. Robert Bartlett, The Budgetary Process and Environmental Policy, in Vig \& Kraft, eds, Environmental Policies in the 1980's at 121, 131, 133 (cited in note 21).

100. Vig \& Kraft, eds, Environmental Policies in the 1980s at $374 \mathrm{n} 27$ (cited in note 21).

101. Department of the Environment Act of 1990, Report of the Senate Committee on Governmental Affairs to accompany S 1006, S Rep No 101-262, 101st Cong, 2d Sess 16 (1990).

102. Id.

103. Pub L No 93-523, 88 Stat 1661 (1974), then codified at 42 USC $\S \S 300 f$ et seq (Supp IV 1974).

104. Pub L No 95-95, 91 Stat 685 (1977), then codified at 42 . USC $\$ \$ 7401$ et seq (Supp I 1977).

105. Pub L No 95-217, 91 Stat 1566 (1977), then codified at 33 USC $\$ \$ 1251$ et seq (Supp I 1977).

106. Pub L No 98-616, 98 Stat 3248 (1984), then codified at 42 USC $\$ \$ 6921$ et seq (Supp II 1984).

107. Pub L. No 99-499, 100 Stat 1613 (1986), then codified at 42 USC $\S \S 9601$ et seq (Supp IV 1986). 
statutory responsibilities and agency funding by imposing even greater and more rigid statutory responsibilities on the agency.

EPA consequently has had far fewer lawyers per significant regulation and fewer dollars for evaluation than other federal agencies. ${ }^{108}$ One former EPA official recently noted that EPA's water program "budget has declined 43 percent in real purchasing power since 1981, although during that period the number of pollutants to be regulated jumped from five to several hundred, and the number of people subject to regulation has risen roughly from 45,000 to 120,000." 109 The number of hazardous waste generators regulated by EPA under RCRA has similarly increased-by a factor of nine during the last ten years. ${ }^{110}$

Hence, Congress has spoken with two different voices to EPA. Each voice reflected the distinct legislative path followed by the authorization and appropriation processes within Congress. Legislators demanded immediate action requiring a massive agency undertaking. At the same time, however, they never provided a remotely commensurate level of agency funding. ${ }^{111}$ Ironically, therefore, while Congress was willing to ask American business and the public to curtail pollution, regardless of the cost, in order to ensure public health, Congress itself refused to fund the level of agency activity necessary for even a good faith effort to implement such an ambitious program. ${ }^{12}$

b. Executive Branch Oversight. OMB was naturally hostile to the federal environmental statutes of the 1970s because those laws took little account of their economic impact. The White House exhibited a similar bias, perhaps because of its enhanced sensitivity to those national economic indicators that are often utilized to measure the relative success of an administration. ${ }^{113}$ Such concerns likely prompted the White House's and OMB's persistent requests for low funding of EPA's environmental programs.

The executive branch's funding requests were not, however, the only expression of its concerns. The White House ventured into pending litigation

108. Cohen, EPA: A Qualified Success at 182 (cited in note 84).

109. Am Bar Assn Standing Committee on Environmental Law, Environmental Compliance: Is the System Working? 20 (Presentation before the 18th Annual Conference on the Environment, May 1920, 1989) (remarks of William Drayton).

110. EPA Office of Solid Waste and Emergency Response, The Nation's Hazardous Waste Management Program At a Crossroads: The RCRA Implementation Study 7 (EPA, July 1990) ("EPA, Program at a Crossroads").

111. Bryner, Bureaucratic Discretion at 118 (cited in note 37) (noting that Congress "has imposed overwhelming responsibilities on the agency to remedy an almost unlimited array of environmental problems, without providing adequate resources to even begin to solve these problems").

112. See William F. Rodgers, The Lesson of the Red Squirrel: Consensus and Betrayal in the Environmental Statutes, 5 J Contemp Health L \& Pol 161 (1989); William F. Rodgers, The Lesson of the Owl and the Crous: The Role of Deception in the Evolution of the Environmental Statutes, $4 \mathrm{~J}$ Land Use \& Envir L 377 (1989).

113. Presidential Management of Rulemaking in Regulatory Agencies 25 (Natl Acad Pub Admin, 1987) ("NAPA, Presidential Management"); Melnick, Regulation and the Courts at 34-35 (cited in note 8). The White House was reportedly largely disinterested in environmental law until its economic costs became more apparent. Bach, Governmental Constraints at 166-68 (cited in note 35). 
to express its interests ${ }^{114}$ and sometimes became directly involved in agency rulemaking. ${ }^{115}$ Of even greater historical significance was the substantive role OMB defined for itself in reviewing proposed EPA regulations to influence their final content. ${ }^{116}$ Both the White House and OMB were motivated at least in part by fear of possible "capture" of agency political appointees by career staff. 117

The OMB review process began, not coincidentally, just a few months after EPA commenced operations, and has gradually and inexorably increased in significance ever since. ${ }^{118}$ Under President Nixon, the process was dubbed the "Quality of Life Review" and focused primarily on the economic impact of EPA rules."19 Under President Ford, EPA was required to submit an inflation impact statement along with every proposed major regulation or rule. ${ }^{120}$ President Carter issued an executive order requiring each agency to prepare a regulatory analysis for every proposed regulation that either would cost the economy more than $\$ 100$ million or threatened to cause a major price increase. $^{121}$ The executive order directed OMB to oversee the order's implementation. ${ }^{22}$ Under all three presidents, frequent and significant confrontations resulted between OMB and EPA concerning proposed EPA rules. ${ }^{123}$

114. See Mercury Pollution and Enforcement of the Refuse Act of 1899, Hearings before the Subcommittee on Conservation and Natural Resources of the House Committee on Government Operations, 92d Cong, Ist \& 2d Sess, 1134-1228, $1281-1363$ (1971 \& 1972) (oversight hearings on White House interference with pending Department of Justice enforcement action against alleged polluter).

115. See Bach, Governmental Constraints at 177 (cited in note 35).

116. OMB was joined initially in its efforts by NIPCC, which the President had created and affiliated with the Department of Commerce in order to ensure that industry would have an effective voice in shaping federal environmental protection policy. See notes 27, 28 and accompanying text. NIPCC is credited with having made high ranking administration officials, including the President, more appreciative of the costs of pollution control. Steck, 5 Envir L at 268-69 (cited in note 27). NIPCC also commented on EPA proposed rules outside of the time provided for public notice and comment under the Administrative Procedure Act, 5 USC $\$ \$ 551$ et seq. Steck, 5 Envir L at 274-79 (cited in note 27). As described above (see note 28 ), Congress ultimately retaliated by cutting off any funding for the council.

117. See Erik Olson, The Quiet Shift of Power: Office of Management and Budget Supervision of Environmental Protection Agency Rulemaking Under Executive Order 12291, 4 Va J Nat Res L 1, 11, 12 n35 (1984); Robert Percival, Checks without Balance: Executive Office Oversight Of the Environmental Protection Agency, 54 L \& Contemp Probs 127 (Autumn 1991).

118. On May 21, 1971, OMB Director George Schultz informed Administrator Ruckelshaus that OMB and the Department of Commerce had to clear EPA regulations prior to their promulgation. Marcus, Promise and Performance at 125 (cited in note 11). See generally Percival, 54 L \& Contemp Probs 127 (cited in note 117); V. Kerry Smith, Environmental Policymaking under Executive Order 12291: An Introduction, in V. Kerry Smith, ed, Environmental Policymaking under Reagan's Executive Order 3-5 (U North Carolina Press, 1984).

119. See Bach, Governmental Constraints at 168-71, 173-74, 178-81 (cited in note 35); J. Clarence Davies \& Charles Lettow, The Impact of Federal Institutional Arrangements, in Erica Dolgin \& Thomas Guilbert, eds, Federal Environmental Law 126, 136-37 (West, 1973); Olson, 4 Va J Nat Res L at 9.10 (cited in note 117).

120. See Exec Order 11821, 3 CFR 926 (1971-1975), amended by Exec Order 11949, 3 CFR 161 (1977).

121. Exec Order 12044, 3 CFR 152 (1979).

122. Id.

123. See NAPA. Presidential Management at 25 (cited in note 113); Implementation of the Clean Air Act of 1970. Hearings before the Subcommittee on Air and Water Pollution of the Senate Committec 
The review process reached its zenith under President Reagan and his first OMB director, David Stockman. ${ }^{124}$ Stockman believed that EPA rules "would practically shut down the economy if they were put into effect," and he was therefore determined to establish "a whole new mindset down at EPA."125 An OMB official under Stockman reportedly asked one applicant for the EPA administrator position whether he " $[w]$ ould . . . be willing to bring EPA to its knees." 126

The result was the establishment of the Presidential Task Force on Regulatory Relief, chaired by then Vice President Bush, and the issuance of Executive Order 12291.127 The task force identified specific federal regulations for revision in order to provide business with regulatory relief. ${ }^{128}$ EPA had promulgated a disproportionate number (more than half) of those regulations targeted by the task force. ${ }^{129}$ Executive Order 12291, like executive orders issued by prior presidents, authorized OMB to review proposed agency regulations. ${ }^{130}$ Unlike its predecessors, however, Executive Order 12291 took the further step of requiring OMB approval of the regulatory analysis that accompanied all major regulations, unless such approval was prohibited by statute. ${ }^{131}$ OMB's leverage over agencies such as EPA therefore dramatically increased. OMB's power of review and ensuing power to delay regulations enabled OMB, in effect, to compel modifications of EPA's proposed rules to satisfy OMB's fiscal concerns. ${ }^{132}$ As in prior

on Public Works, 92d Cong, 2d Sess 3-177, 224-328 (1972) (accusations that OMB undermining EPA authority); John Quarles, Cleaning Up America: An Insider's View of the environmental Protection Agency 117 19 (Houghton Mifflin, 1976) (noting that Ruckelshaus reportedly threatened to quit unless President Nixon agreed that EPA and not OMB or the White House would have final say on content of EPA rules); Special Report: Office of Management and Budget Plays Critical Part in Environmental Policymaking, Faces Little External Review, 7 Envir Rptr Curr Dev (BNA) 693 (1976); Landy, Roberts \& Thomas, EPA: Asking the Wrong Questions at 66-75 (cited in note 32) (discussing conflict between OMB (and White House) and EPA (Administrator Costle) concerning promulgation of ozone standard); see also Anne Burford, Are You Tough Enough? 83 (McGraw-Hill, 1986) (Gorsuch confrontation with OMB over promulgation of EPA rule). Anne Gorsuch changed her last name to "Burford" following her marriage in February 1983, which was shortly before she resigned as EPA administrator.

124. According to William Ruckelshaus, however, the problems presented by OMB review that he faced as administrator of EPA in the early 1970s were "exactly the same" as those he faced as administrator in 1983 and 1984. See Rochelle L. Stanfield, EPA Administrator Lee Thomas Is More A Manager Than A Policymaker, 18 Natl L J 39l, 392 (Feb 15, 1986).

125. Constance Holden, The Reagan Years: Environmentalists Tremble, 210 Science 988 (Nov 28, $1980)$.

126. Burford, Are you Tough Enough? at 84 (cited in note 123).

127. See Presidential Task Force on Regulatory Relief, 17 Weekly Comp Pres Docs 33 (Jan 22, 1981).

128. See Exec Order 12291, 17 Weekly Comp Pres Docs 124 (Feb 17, 1981).

129. Burford, Are You Tough Enough? at 121 (cited in note 123).

130. See Bach, Governmental Constraints at 178-81 (cited in note 35); Natl Res Council, ed, 2 Decisionmaking in the Environmental Protection Agency at 88 (cited in note 97).

131. NAPA, Presidential Management at 25 (cited in note 113); Olson, 4 Va J Nat Res L at $10-12$ (cited in note 117); Charles E. Ludlam, The Reagan Regulatory Program in Context 57 (Alliance for Justice, 1981).

132. Olson, 4 Va J Nat Res $\mathrm{L}$ at 43-46, $5 \mathrm{I}$ (cited in note 117). In her account of her tenure as EPA administrator, Anne Gorsuch describes the OMB process for reviewing EPA's budget and rules. See Burford, Are You Tough Enough? at 75-84 (cited in note 123). When Gorsuch once approved final EPA rules without waiting for OMB clearance, an OMB official warned her: "There's a price to pay for this, and you've only begun to pay." Id at 83 . 
administrations, the practice generated considerable controversy and was widely criticized, although to a much greater degree under the Reagan Administration. ${ }^{133}$

The relative power of OMB did not significantly decrease during President Reagan's second term, nor has it more recently under President Bush. While OMB's review is now subject to more public scrutiny, ${ }^{134}$ it remains a strong force in the development of EPA regulations. During 1985, 1986, and 1987, EPA revised $74.5,66.2$, and 66.2 percent, respectively, of agency rules reviewed by OMB. ${ }^{135}$ When disagreements between EPA and OMB have arisen, OMB has invariably won. ${ }^{136}$ OMB continues to "hold" EPA rules for months and years based on OMB concerns with the cost of compliance with a rule. ${ }^{137}$

Finally, while the OMB review process formally applies to all major agency regulations, its practical impact on EPA remains far greater than on other agencies. In 1988, for example, OMB rejected EPA regulations three times more frequently than those presented by other agencies: 21 percent of the

133. See, for example, Role of OMB in Regulation, Hearings before the Subcommittee on Oversight and Investigations of the House Committee on Energy and Commerce, 97th Cong, 1st Sess 1 (1982); EPA's Asbestos Regulations, Hearing before the Subcommittee on Oversight and Investigations of the House Committee on Energy and Commerce, 99th Cong, 1st Sess 1 (1985); EPA's Asbestos Regulations: Report on a Case Study of OMB Interference in Agency Rulemaking, Subcommittee on Oversights and Investigations of the House Committee on Energy and Commerce, 99th Cong, 1st Sess 1 (Comm Print, 1985); EPA: Investigation of Superfund and Agency Abuses Part 3, Hearings before the Subcommittee on Oversight and Investigation of the House Committee on Energy and Commerce, 98th Cong, lst Sess 5-8, 79-83 (1983) (testimony of John Daniel, administrator's chief of staff).

134. In October 1986, OMB agreed (upon federal agency request) to provide the agency with copies of written material that it receives from persons outside the federal government and to advise the agency of any oral communications. OMB also agreed to invite the agency to schedule meetings with those same individuals concerning the agency rules, to make available in a public reading room all written material received, as well as to list all meeting and all communications with outside persons pertaining to the agency rules. See NAPA, Presidential Management at 3 (cited in note 113); Bernard Rosen, Holding Government Bureaucracies Accountable 51 (Praeger, 2d ed 1989); Bryner, Bureaucratic Discretion at 118 (cited in note 37); Harold Bruff, Presidential Management Of Agency Rulemaking, 57 Geo Wash L Rev 533 (1989). Just last year, in response to increased congressional pressure (including a threat to eliminate relevant OMB funding and to limit OMB review to 60 days), the President apparently agreed to limit OMB review. See Congress, White House Agree on Executive Order to Limit OMB Review of EPA Regs, 11 Inside EPA 3 (July 20, 1990); text accompanying note 351; see also White House Backs Out of Deal Limiting OMB Authority Over EPA Rules, 11 Inside EPA 1 (June 15, 1990).

135. NAPA, Presidential Management at 24 (cited in note 113).

136. See OMB Said to Have Influenced About One-Third of Regulations Proposed by EPA in 1986, 17 Envir Rptr (BNA) 1616 (Jan 1987).

137. For instance, OMB "held" a rule proposed by EPA pursuant to the Resource Conservation and Recovery Act, 42 USC $\$ \$ 6901$, et seq, from October 1988 to July 1990. See EPA Releases Delayed Corrective Action Rule, Calls It "Milestone" In Cleanup Of RCRA Facilities, 21 Envir Rptr (BNA) 475 (July 13, 1990). Reportedly, OMB Director Richard Darman earlier had instructed his agency to "kill this" and "OMB's attitude has been that this rule is never going to see the light of day." See Budget Office, EPA Remain Far Apart on Draft Corrective Action Rule, 21 Envir Rptr (BNA) 187 (May 18, 1990); OMB Contimues to Hold RCRA Cleanup Rule Hostage, to Chagrin of EPA, 11 Inside EPA 9-10 (June 8, 1990). See also, for example, OMB Objections May Force EPA to Drop Source Separation from Incinerator Proposal, 20 Envir Rptr (BNA) 1330 (Nov 24, 1989); EPA Struggles with OMB to Retain its Recycling Plan in Waste Incinerator Regs, 10 Inside EPA 1, 9-10 (Dec 1, 1989). 
agency's regulations were either disapproved or withdrawn by EPA. ${ }^{138}$ In addition, although EPA's rules amount to only about 4 percent of all OMB activities, four out of OMB's thirty-two desk officers review EPA rules. ${ }^{139}$

c. Judicial Oversight. Partly to prevent agency capture, Congress encouraged judicial oversight of EPA by including citizen suit and judicial review provisions in each of the environmental statutes and by requiring EPA to follow decisionmaking procedures more rigorous than those normally employed in informal notice and comment rulemaking. ${ }^{140}$ The citizen suit provisions routinely allowed successful plaintiffs to recover their attorneys' fees. ${ }^{141}$ Both environmental organizations and industry took advantage of the increased judicial access and together challenged between 80 and 85 percent of EPA's major decisions. ${ }^{142}$

The deadlines and mandatory duties contained in the various federal laws, along with their carefully crafted legislative histories, provided environmentalists with enormous leverage over EPA through litigation, which they used as their dominant tool to influence agency decisions. ${ }^{143}$ Whenever EPA failed to meet a deadline, or otherwise to satisfy a statutory obligation, which was inevitably often, environmentalists used litigation to compel EPA to negotiate with them in drafting a consent decree. ${ }^{144}$ Environmentalists utilized the consent decree and the threat of contempt sanctions to control the agency's future actions. ${ }^{145}$ The filing of lawsuits also provided environmentalists with media events that provided publicity for their cause and incidentally aided fundraising efforts. ${ }^{146}$ The media was naturally receptive to accusations of agency malfeasance, and the result was a steady stream of negative articles about EPA in the national press.

138. OMB Subjects EPA Regs To More Scrutiny Than Other Agencies, Says Watchdog, 10 Inside EPA 8 (Nov 3, 1989) (describing OMB Watch report).

139. Id; see Office of Management and Budget Influence on Agency Regulations, 99th Cong, 2d Sess 19 (Comm Print, 1986) (S Prt, No 99-156).

140. See Stewart, 69 Cal L Rev at 1366 (cited in note 37); Muskie, 18 Envir L Rptr at 10082-83 (cited in note 37) ("Congress anticipated bureaucratic interference with the 1970 CAA and incorporated public access to the courts in that law and virtually every other environmental statute since enacted. Today there are dozens of citizen suits pending at all levels of the judiciary."); see generally, Comment, The Rise of Citizen-Suit Enforcement in Environmental Law: Reconciling Private and Public Attorneys General, 81 Nw U L Rev 220 (1987) (authored by Jeannette Austin).

141. Ruckelshaus v Sierra Club, 463 US 680, 682 nl, 683 (1983).

142. See note 54 .

143. The day after EPA commenced operations, the Environmental Defense Fund filed a lawsuit against the agency to compel it to cancel the registration of two pesticides. Christopher Bosso, Pesticides and Politics: The Life Cycle of a Public Issue 153 (U Pittsburgh Press, 1987).

144. See, for example, Natural Resources Defense Council, Inc. v Train, 519 F2d 287 (DC Cir 1975) (the "Flannery decree").

145. Natl Res Council, ed, 2 Decisionmaking in the Environmental Protection Agency at 70 (cited in note 97).

146. Bosso, Pesticides and Politics at 216 (cited in note 143). An incidental benefit of Secretary Watt's apparent antagonism toward federal environmental pollution control efforts was that it prompted tremendous increases in memberships in, and donations to, national environmental organizations such as the Sierra Club. Natural Resources Defense Council, and Environmental Defense Fund. Id at 216 (reporting that Sierra Club membership increased from 180,000 to 300,000 from 1980 to 1982). 
There were likewise those who have had tremendous economic incentives to use litigation to challenge EPA decisions. EPA's regulations impose huge costs on a wide segment of economic activity; indeed, no significant economic activity has been unaffected. ${ }^{147}$ The General Accounting Office recently estimated that the cost of EPA programs since 1970 has been $\$ 700$ billion, and now total about $\$ 86$ billion each year. ${ }^{148}$ The estimated annual cost of complying with the 1976 RCRA law was itself $\$ 6$ billion, and the Congressional Budget Office estimates the annual cost of compliance with the 1984 amendments to RCRA at between $\$ 3$ and $\$ 7$ billion. ${ }^{149}$ With an average cost of $\$ 30$ million per site, the cost of cleaning up the 2,000 abandoned and inactive hazardous waste sites now thought to require cleanup will be $\$ 60$ billion. ${ }^{150}$ The new Clean Air Act Amendments of 1990 will reportedly require an additional $\$ 40$ to $\$ 50$ billion in pollution control expenditures. ${ }^{151}$

Proclaiming "a new era in the history of the long and fruitful collaboration of administrative agencies and reviewing courts," 152 the judiciary did not shy away from careful examination of EPA's actions. ${ }^{153}$ Especially during EPA's early years, courts of appeals frequently rejected the agency's efforts to relax the statutory mandates through "loose" construction of their terms. 154 The courts also often remanded agency rulemaking for further proceedings based on perceived inadequacies in the rulemaking record. Environmentalists benefitted from many of the courts' more expansive constructions of the federal environmental laws. ${ }^{155}$ Industry, however, benefitted from many of

147. Natl Res Council, ed, 2 Decisionmaking in the Environmental Protection Agency at 2 (cited in note 97) ("the regulatory reach of the EPA program is probably unparalleled").

148. S Rep 101-262 at 15 (cited in note 101).

149. Dower, Hazardous Wastes at 178-79 (cited in note 90).

150. Id at 179.

151. Barnaby Feder, The Struggle in Congress; Focus Shifts to Rules on Cleaner Air for Cars, Chemical, and Steel Makers, NY Times A1 1 col 1 (Oct 24, 1990).

152. Environmental Defense Fund, Inc. v Ruckelshaus, 439 F2d 584, 597 (DC Cir 1971); see also Greater Boston Television Corporation v F.T.C., 444 F2d 841, 851 (DC Cir 1970) (noting "partnership" between courts and agencies).

153. See Leventhal, 122 U Pa L Rev at 512 (cited in note 41 ).

154. See, for example, Natural Resources Defense Council v Train, 545 F2d 320 (2d Cir 1976) (holding that EPA has mandatory duty under CAA to use NAAQS upon determining that pollutant may adversely affect public health); Natural Resources Defense Council, Inc. v EPA, 489 F2d 390 (5th Cir 1974) (upholding challenge to EPA's approval of state plan allowing emissions reduction credit for tall stack dispersion); Natural Resources Defense Council, Inc. v EPA, 475 F2d 968, 970 (DC Cir 1973) (holding that EPA lacked authority to postpone deadlines for submission of state implementation plans under the Clean Air Act or to grant extensions for attainment of national primary ambient air standards without following statutory procedures); Environmental Defense Fund, Inc. v Ruckelshaus, 439 F2d 584, 598 (DC Cir 1971) (sustaining challenge to EPA refusal to suspend registration of DDT pesticide).

155. No doubt the best known example was the judicial ruling that the Clean Air Act required EPA to prevent significant deterioration in the air quality in those areas that already met national ambient air quality standards. See, for example, Sierra Club v Ruckelshaus, 344 F Supp 253 (D DC 1972), aff d, 4 ERC 1815 (DC Cir 1972); see Melnick, Regulation and the Courts at $71-112$ (cited in note 8). According to one commentator's tabulations, environmentalists won more often than did industry in federal environmental cases during both the $1970 \mathrm{~s}$ and 1980s. See Jeremy Rabkin. Judicial Compulsions 273 n35 (Basic Books, 1990), citing Lettie Wenner, The Reagan Era in Environmental Litigation (unpublished paper presented at the 1988 American Political Science Association Convention). 
the judicial remands of agency rules. ${ }^{156}$ The deadlines compelled agency decisions within exceedingly short time frames, and, due to the scientific complexity of the mechanics of environmental pollution and the associated scientific uncertainty, the scientific bases for agency rulings were often quite sparse and subject to effective criticism. ${ }^{157}$

In addition, even when industry plaintiffs fared poorly in their initial efforts to persuade courts of appeals to require or permit EPA's consideration of the adverse economic impact of its rules on business, ${ }^{158}$ individual industry defendants in EPA enforcement actions appear to have been more successful in their efforts to have trial courts fashion remedies in response to economic factors. ${ }^{159}$ One explanation for the disparity is the differing perspectives of the district courts and the courts of appeals: courts of appeals are possibly more influenced by academic theories of agency capture than are district courts; district courts, unlike courts of appeals, are closer to the impact on local economics of applying the law according to its strict terms. ${ }^{160}$

d. Congressional Oversight. Perhaps the most important (and most often overlooked) of the institutional forces that have buffeted EPA has been the operation of congressional oversight, ${ }^{161}$ long referred to as Congress's "neglected" function. ${ }^{162}$ Congress did not quietly disappear following its passage of the federal environmental protection laws under EPA's jurisdiction. It has actively overseen the agency's implementation of those laws through informal agency contacts, General Accounting Office and Office of Technology Assessment investigations, agency reporting requirements, formal oversight hearings, confirmation hearings, appropriation hearings,

156. Kennecolt Copper v EPA, 462 F2d 846 (DC Cir 1972); Portland Cement Assoc. v Ruckelshaus, 486 F2d 375, 401-02 (DC Cir 1973); International Harvester Company y Ruckelshaus, 478 F2d 615, 647-50 (DC Cir 1973); South Terminal Corp. v EPA, 504 F2d 646, 662-67 (1st Cir 1974).

157. CEQ Sixteenth Annual Report at 13 (cited in note 53). Illustrative is the recent decision of the United States Court of Appeals for the District of Columbia Circuit in American Mining Congress $v$ EPA, 907 F2d 1179, 1188-91 (DC Cir 1990), in which the court of appeals reversed and remanded for further administrative proceedings EPA's decision to list six materials as "hazardous substances" under RCRA. The court acknowledged that the inadequacy of the agency's record may have resulted because "EPA was pressured to list the six materials quickly in light of this court's [prior] order." Id at 1191 .

158. See, for example, Union Electric Co. v EPA, 427 US 246, 256 (1976); EPA v National Crushed Stone Assoc., 449 US 64, 72 (1980).

159. See Melnick, Regulation and the Courts at 193-238 (cited in note 8)

160. Id at 156-64, 236-37, 354, 368-71.

161. For a more detailed discussion of the issues related to congressional oversight of EPA, see Richard J. Lazarus, The Neglected Question of Congressional Oversight of EPA: Quis Custodiet Ipsos Custodes (Who Shall Watch the Watchers Themselves)?, 54 L \& Contemp Probs 205 (Autumn 1991).

162. Kenski \& Kenski, Congress Against the President at 104 (cited in note 38); see generally, Joseph Harris, Congressional Control of Administration (Brookings Inst, 1964); Lawrence Dodd \& Richard Schott, Congress and the Administrative State 155-323 (John Wiley, 1979); Study on Federal Regulation: II Congressional Oversight of Regulatory Agencies, S DOC No 95-26, 95th Cong, lst Sess 1 (1977); Congressional Oversight of Regulatory Agencies: The Need to Strike A Balance and Focus On Performance 7-17 (Natl Acad Pub Admin, 1988) ("NAPA, Oversight Study"); Morris Ogul, Congress Oversees the Bureaucracy 5-12 (U Pittsburgh Press, 1976). 
appropriation riders, inspector general reports, and amendments of the laws themselves. ${ }^{163}$

Much of the oversight has been driven by a desire to prevent EPA's capture by industry and by those in the White House and OMB who are perceived (accurately) as unsympathetic to the statutory policies of the laws within EPA's jurisdiction. ${ }^{164}$ Others within Congress, however, have been more concerned about the possibility of bureaucratic or environmentalist capture and have used the same oversight tools to counsel EPA against strict application of those laws. ${ }^{165}$ Because the statutes demand the impossible of EPA and require EPA to demand the impossible, or at least very painful, from others, there has historically been plenty to fuel criticism from both constituencies within Congress. ${ }^{166}$ "EPA bashing" has been commonplace on Capitol Hill as legislators from both sides of the aisle have perceived its political advantages. ${ }^{167}$

Indeed, a culture of condemnation of EPA developed early on in Congress. Fueled by Senator Edmund Muskie's growing presidential aspirations and by increasing alienation between a Democratic Congress and President Nixon, Muskie's Air and Water Pollution Subcommittee of the Senate Committee on Public Works quickly established itself as EPA's critical overseer. ${ }^{168}$ Muskie and others sharply criticized agency officials in widely publicized media events. They strongly urged those officials to consult with the subcommittee prior to making any important agency decisions. Muskie also warned EPA officials against allowing either the White House or OMB to

163. See generally NAPA, Oversight Study at 9-12 (cited in note 162) (describing congressional oversight methods); Bernard Rosen, Holding Government Bureaucracies Accountable at $62-79$ (cited in note 134).

164. Increased congressional oversight of executive branch agencies parallels increased presidential oversight of those agencies and thus expresses the ongoing competition between the two branches for control over agency policy. See William West \& Joseph Cooper, Legislative Influence v. Presidential Dominance: Competing Models of Bureaucratic Control, 104 Pol Sci Q 581, 589-91 (Winter 1989-90). The agencies are "agents of different and divided masters" and their operation "reflects the ongoing tensions between the White House and Capitol Hill." Wilson, Bureaucracy at 259 (cited in note 16). For this same reason, the amount of oversight of federal agencies has also likely increased in recent years because of the persistence of different political parties in control of the executive and legislative branches. See Joel Aberbach, Keeping A Watchful Eye: The Politics of Congressional Oversight 59-60 (Brookings Inst, 1990) (noting 26.2\% more oversight in years of split partisanship between 1961 and 1977); NAPA, Oversight Study at 1 (cited in note 162). There is a natural disinclination to "rake thru coals" those of your same political party. See Ogul, Congress Oversees the Bureaucracy at 18, 136-37 (cited in note 162).

165. Melnick, Regulation and the Courts at 317-19 (cited in note 8).

166. See Comment, Congress in 1984: A Mixed Bag, 14 Envir L Rptr 10449 (Dec 1984) (emphasizing degree of congressional oversight); Comment, Congress in 1983: Much Oversight, Little Legislation, 14 Envir L Rptr 10005 (Jan 1984) (same).

167. William Ruckelshaus, Looking Back; Looking Ahead: EPA, 16 EPA J 14, 15 (Jan/Feb 1990). The barrage of congressional criticism may have the incidental effect of encouraging more intensive judicial review. See Rodgers, 3 Environmental Law $\$ 5.4$ at 56 (cited in note 82) ("[L]egislative oversight by the congressional committees is aggressive and skeptical, supplying the courts with tempting snippets of legislative history and emboldening them with tales of the frailties of EPA decisionmaking.").

168. The Committee on Public Works created the Air and Water Pollution Subcommittee in 1963 and named Senator Muskie as its first chair. See History of the Senate Committee on Environment and Public Works, S Doc No 100-45, 100th Cong, 2d Sess 11 (Dec 1988). 
influence unduly the agency's implementation and enforcement of the laws. ${ }^{169}$

The practice was not confined to Muskie's subcommittee, the Senate, or to those who believed that EPA was not doing enough. ${ }^{170}$ There were plenty of congressional overseers equally concerned with potential agency overreaching. For instance, as a result of internal compromise, EPA's budget was initially within the jurisdiction of the House subcommittee chaired by Representative Jamie Whitten, an outspoken critic of many of the environmental laws. ${ }^{171}$ He accordingly used the appropriations process to conduct lengthy inquiries into the details of the agency's implementation of those laws. ${ }^{172}$ He quite openly opined that Congress may not actually have intended full implementation of the laws that it had passed: "Sometimes a fellow might feel that if he writes a law three times as strong as he wants it to be, maybe it will be carried out 100 percent." 173 Whitten also described his ability to "limit use of money" to cut back on environmental laws. ${ }^{174}$

169. Lazarus, 54 L \& Contemp Probs at 214 (cited in note 161).

170. Nor was it limited to those time periods during which Congress and the White House were headed by different political parties. Although there is a tendency for less oversight when both are of the same party (see note 164), there was not markedly less intense oversight of EPA by the Senate between 1981 and 1986 when the Republicans were the majority party. The ranking Republicans on the relevant authorization committees and subcommittees, like the ranking Democrats, generally supported the environmental protection policies reflected in the statutes previously enacted. See Melnick, Regulation and the Courts at 32 (cited in note 8).

171. Bosso, Pesticides and Politics at 154 (cited in note 143).

172. EPA Administrator William Ruckelshaus first appeared before Representative Whitten's committee in 1971 to defend the agency's budget request for fiscal year 1972. The tenor of the hearings strongly reflected Whitten's intention to use the appropriations process to oversee the operations of the agency and its substantive decisions. Agriculture-Environmental and Consumer Protection Appropriations for Fiscal Year 1972, Hearings before a Subcommittee of the House Committee on Appropriations, 92d Cong, 1 st Sess 1 (1971). Whitten questioned Ruckelshaus about the hazards posed by DDT, id at 382, which Whitten discounted, and Whitten and others on the committee demanded agency responses to a wide-ranging series of questions. See, for example, id at 362-63 (questioning operation of specific EPA lab); id at 365-66 (questioning effort of small Mississippi town to obtain land from federal government); id at 398 (questioning EPA's decision to ban aldrin and dieldrin); id at 410 (questioning solid waste project in Alabama town). The same pattern repeated itself for the next several vears. See Agriculture-Environmental and Consumer Protection Appropriations for Fiscal Year 1973, Hearings before a Subcommittee of the House Committee on Appropriations, 92d Cong, 2d Sess 1 (1972); Agriculture-Environmental and Consumer Protection Appropriations for Fiscal Year 1974, Hearings Before a Subcommittee of the House Committee on Appropriations, 93d Cong, 1st Sess 1 (1973); Agriculture-Environmental and Consumer Protection Appropriations for fiscal year 1975, Hearings before a Subcommittee of the House Committee on Appropriations, 93d Cong, 2d Sess 1 (1974). See Davies \& Davies, The Politics of Pollution at 73-77 (cited in note 11). In the hearing on the budget for Fiscal Year 1974, Representative Whitten sharply questioned Ruckelshaus about his adverse decision regarding DDT. See Agriculture-Environmental and Consumer Protection Appropriations for Fiscal Year 1974, Hearings before a Subcommittee of the House Committee on Appropriations, 93d Cong, 1st Sess 475-76 (1973). He also questioned whether EPA was encouraging lawsuits by environmentalists against the agency. Id at 240 .

173. Department of Housing and Urban Development-Independent Agencies Appropriations for Fiscal Year 1973, Hearings before the Subcommittee on HUD-Independent Agencies of the House Committee on Appropriations, 92d Cong, 2d Sess 350 (1972) (statement of Rep. Whitten).

174. Id. Representative Whitten surrendered subcommittee jurisdiction over EPA in 1974 to avoid a confrontation and possible liberal challenge to his eventual succession to chair of the House Appropriations Committee. Foreman, Signals from the Hill at 195 (cited in note 36); see Bosso, 
Oversight of EPA ultimately spread to both chambers and to authorization, government operations, and appropriations committees. The expansion roughly coincided with a general increase in congressional appreciation of the political advantages of "subcommittee government"175 and "fire alarm" oversight, ${ }^{176}$ which in turn spurred a dramatic increase in committee staff and oversight during the last few decades.177 When EPA failed to meet statutory deadlines, members of Congress held hearings in which they chastised the agency for neglecting the public trust. ${ }^{178}$ Conversely, when EPA made politically unpopular decisions in an effort to comply with its statutory mandates, other members of Congress promptly joined in the public denunciation (including some who originally sponsored the strict environmental laws). ${ }^{179}$

EPA's exposure to congressional criticism has been especially great because of the structure (or lack thereof) of congressional oversight. ${ }^{180}$ EPA's jurisdiction is so sweeping, and therefore important to so many interest groups, that the demand for its oversight has grown commensurately among the committees and subcommittees in Congress. Most committees can find some nexus between their assigned jurisdiction and some aspect of EPA's work.

The result has been increasing fragmentation of oversight authority over EPA. Eleven standing House committees, nine standing Senate committees

Pesticides and Politics at 189 (cited in note 143). Whitten is presently chair of the House Appropriations Committee.

175. Congressional reforms in the 1970 s led to the rise of the power of the subcommittee. In the 1950 s, full committees held most hearings and debates; subcommittees held only 20 to $30 \%$ of the hearings. By the late 1970 s and the 95th Congress, subcommittees held over $90 \%$ of all hearings: their decisions were more authoritative; full committee chairs were restricted to being chair of one subcommittee; and subcommittee chairs were increasingly the floor manager for bills. See Lawrence Dodd \& Bruce Oppenheimer, The House in Transition: Change and Consolidation, in Dodd \& Schott, Congress and the Administrative State at 40-48 (cited in note 162).

176. See Matthew D. McCubbins \& Thomas Schwartz, Congressional Oversight Overlooked: Police Patrols Versus Fire Alarms, 28 Am J Pol Sci 165-76 (1984). Between 1968 and 1976, the number of House and Senate oversight hearings per Congress quadrupled and doubled, respectively. John Chubb, Interest Groups and the Bureaucracy 47 (Stanford U Press, 1983)

177. See Aberbach, Keeping a Watchful Eye at 46 (cited in note 164); Peter Shane, Legal Disagreement and Negotiation in a Government of Laus: The Case of Executive Privilege Claims Against Congress, $71 \mathrm{Minn}$ L. Rev 461, 464 (1987) (congressional staff grew from 7,091 to 17,963 from 1960 to 1984, and number of subcommittee staff grew from 910 to 3,183 during that same period); Foreman, Signals from the Hill at 16 (cited in note 36) (personal and committee staff grew from 1,150 in 1930 to 10,679 by the end of the 1970s).

178. See, for example, Federal Insecticide, Fungicide, and Rodenticide Act, Hearings before the House Committee on Agriculture, 95th Cong, Ist Sess 1 (1977); Hazardous Waste Disposal (Part 2), Hearings before the Subcommittee on Oversight and Investigations of the House Committee on Interstate and Foreign Commerce, 96th Cong, 1st Sess 1 (1979); Oversight of Hazardous Waste Management and the Resource Conservation and Recovery Act, Hearings before the Subcommittee on Oversight of Government Management of the Senate Committee on Governmental Affairs, 96th Cong, Ist Sess 1 (1979); Hazardous Waste Matters, Hearings before the Subcommittee on Oversight and Investigation of the House Committee on Interstate and Foreign Commerce, 96th Cong, 2d Sess 1 (1980).

179. See, for example, 119 Cong Rec 41127.29 (Dec 12, 1973) (remarks of Rep. Hudnut); 119 Cong Rec 41728 (Dec 12, 1973) (remarks of Rep. Boland); 119 Cong Rec 41305 (Dec 13, 1973) (remarks of Rep. Kazen); see generally Quarles, Cleaning Up America at 201-11 (cited in note 123).

180. Dodd \& Schott, Congress and the Administrative State at 173-77 (cited in note 162). 
and up to one hundred of their subcommittees currently share environmental jurisdiction. ${ }^{181}$ The number of times EPA officials testify before Congress is staggering. EPA officials have testified over 200 times and before as many as forty different congressional committees and subcommittees in just one Congress (two calendar years). ${ }^{182}$ Other federal agencies, such as the Consumer Product Safety Commission, Federal Trade Commission, Food and Drug Administration, National Labor Relations Board, Nuclear Regulatory Commission, Occupational Safety and Health Administration, and Securities Exchange Commission, have appeared before congressional committees far less often than EPA; even the Defense Department has appeared before Congress less often in some years. ${ }^{183}$ The National Academy of Public Administration recently studied the degree of congressional oversight of EPA and other federal agencies and concluded that "EPA is in a unique situation, given the pervasiveness of environmental hazards and the large number of committees with jurisdiction over the agency." 184

e. Congressional Prescription. Congress has not confined itself to overseeing EPA's work. In the aftermath of repeated regulatory failures, Congress has favored passing increasingly detailed environmental statutes to guard against agency dereliction in the first instance. ${ }^{185}$ Oversight therefore has been supplemented with prescription.

Amendments to the Clean Air Act and Clean Water Act in 1977, 186 to the Clean Water Act, CERCLA, FIFRA, RCRA, the Safe Drinking Water Act, and TSCA during the $1980 \mathrm{~s},{ }^{187}$ and to the Clean Air Act in $1990,{ }^{188}$ all exhibit the

181. Reilly, 20 Envir Rptr Curr Dev (BNA) at 9 (cited in note 51); see S Rep No 101-262, 101st Cong, 2d Sess 27 (1990) (noting that EPA is overseen by 34 Senate and 56 House committees).

182. For a detailed breakdown of the number of times EPA officials have testified before Congress, see Lazarus, 54 L \& Contemp Probs at 213, Table 1 (cited in note 161).

183. Id at 212; see Study on Federal Regulations: II Congressional Oversight of Regulatory Agencies, S Doc No 95-26, 95th Cong, 1st Sess 81 (1977); see also NAPA, Oversight Study at 32 (cited in note 162 ).

184. NAPA, Oversight Study at 30 (cited in note 162).

185. Portney, Public Policies at 284-86 (cited in note 11); Sydney Shapiro \& Robert Glicksman, Congress, the Supreme Court, and the Quiet Revolution in Administrative Law, 1988 Duke L J 819, 828; William Ruckelshaus, Environmental Protection: A Brief History of the Environmental Movement in America and the Implications Abroad, 15 Envir L 455, 460 (1985); William Ruckelshaus, 16 EPA J at 15 (cited in note 167). The use of increased detail in statutory law to curb agency discretion is not a recent phenomenon. See Arthur MacMahon, Congressional Oversight of Administration: The Power of the Purse, in Theodore Lowi, ed, Legislative Politics U.S.A. 186 (1965). Indeed, from an historical perspective, it is the more traditional legislative approach. See Aberbach, Keeping a Watchful Eye at 20 (cited in note 164); Jeremy Rabkin, Micromanaging the Administrative Agencies, 100 Public Interest 116, 117-18 (Summer 1990).

186. Clean Air Act Amendments of 1977, Pub L No 95-95 (cited in note 104); Clean Water Act, Pub L No 95-217 (cited in note 105).

187. Clean Water Act, Pub L No 100-4, 101 Stat 7 (1987), then codified at 33 USC $\$ \S 1251$ et seq (Supp IV 1987); CERCLA, Pub L No 99-499, 100 Stat 1613 (1986) (cited in note 107); FIFRA, Pub L No 100-532, 102 Stat 2654 (1988), codified at 7 USC $\$ 136$ et seq (1988); RCRA, Pub I. No 98-616, 98 Stat 3221 (1984), codified at 42 USC $\$ \S 6901$ et seq (Supp II 1984); Safe Drinking Water Act. Pub L No 99-339, 100 Stat 642 (1986), then codified at 43 USC $\$$ et seq (Supp IV 1986); TSCA. Pub L No 99-519, 100 Stat 2970 (1986), then codified at 15 USC $\$ \$ 2601$ et seq (Supp IV 1986).

188. Pub L No 101-549, 104 Stat 2391 (1990); see Huge Clean Air Bill's Toxics Tille Sets New Time For Government Regulation, 21 Envir Rptr (BNA) 1357 (Nov 16, 1990), quoting Rep. Waxman: "We're not 
same trend. Each eliminated substantial EPA discretion, imposed more deadlines, and included more prescription. ${ }^{189}$ For example, Congress responded in 1977 to EPA's failure to implement the Clean Air Act's provision governing the emission of toxic air pollutants (section 112) by chastising the agency and compelling it to issue emission standards for four specific pollutants within an impossible time frame. ${ }^{190}$

Congressional reaction in 1984 to EPA's failure to meet RCRA's unrealistic deadlines and a host of other controversies arising from the statute's implementation prompted more legislative prescription. The 1984 amendments to RCRA imposed more than sixty additional deadlines on the agency. ${ }^{191}$ The law dictated precisely when each of a series of regulations had to be published, the dates by which the permits had to be issued, and the substantive criteria that the permits had to contain. ${ }^{192}$ As described by two commentators, the amendments were "dripping with evidence that Congress does not wish to entrust EPA with too much."193 The administrative tasks were no less enormous than those contained in earlier laws. Indeed, the 1984 RCRA amendments extended EPA's jurisdiction to include small volume generators of hazardous waste (numbering approximately 130,000) and 1.4 million underground storage tanks. ${ }^{194}$ Congress simultaneously enhanced the citizen suit provisions of RCRA to promote judicial oversight. ${ }^{195}$

The likelihood that EPA will again fail to meet Congress's mandates seems great. ${ }^{196}$ When EPA does fail, environmentalists and legislators will likely once again widely denounce EPA in the news media. Each agency decision or

going to leave it to EPA this time to use its discretion to enforce the clean air law. We're spelling out what must be done."

189. Shapiro \& Glicksman, 1988 Duke L J at 829-30 (cited in note 185); see Ruckelshaus, 15 Envir L at 460-63 (cited in note 185); Timothy Atkeson, et al, An Annotated Legislative History of the Superfund Amendments and Reauthorization Act of 1986, 16 Envir L Rptr 10359, 10371 (Dec 1986).

190. See John Graham, The Failure of Agency-Forcing: The Regulation of Airborne Carcinogens under Section 112 of the Clean Air Act, 1985 Duke L J 100, 149-50.

191. EESI, Statutory Deadlines at 1 (cited in note 49).

192. See 42 USC \$§ 6921-6925 (1988); see generally Harris, Want \& Ward, Hazardous Waste (cited in note 21 ).

193. James Rogers \& Dorothy Darrah, RCRA Amendments Indicate Hill Distrust of EPA, Legal Times of Washington 28 (Dec 19, 1984); James Florio, Congress As Reluctant Regulator: Hazardous Waste Policy in the 1980s, 3 Yale J Reg 351 (1986).

194. See Dower, Hazardons Wastes at 165-67 (cited in note 90); CEQ Fifteenth Annual Report at 166 (cited in note 91 ).

195. Pub L No 98-616, § 401, 98 Stat 3268 (1984) (amending 42 USC $\$ 6972$ ).

196. According to a recent GAO report, EPA has failed to meet 57 of its CERCLA deadlines and all of its deadlines under the 1987 amendments to the Clean Water Act. See Nomination of William K. Reilly at 95, 214 (cited in note 35); GAO says EPA missed half of SARA deadlines, ciles potential for jeopardizing human health, 19 Envir Rptr (BNA) 40 (Feb 3, 1989). See Rogers \& Darrah, Legal Times of Washington at 33 (cited in note 193) ("The sheer volume of EPA studies and regulations mandated and the unrealistic statutory deadlines virtually guarantee that EPA will find itself in default on a number of accounts. History demonstrates that this type of default triggers a number of unpleasant events: congressional attacks, lawsuits by environmental groups, and worst of all, hastily conceived regulations."); HR Rep 99-253, 99th Cong, Ist Sess 322 (1986) (dissenting views of Reps. DeLany and Monson regarding report of 1986 amendments to CERCLA) ("The Committee version adopts scheduling requirements that effectively force the EPA to fail. ... This is a disastrous move which threatens the future viability of the program. The EPA, not the courts, must control the cleanup mechanism."). 
"lapse" will prompt new litigation. Consent decrees will dictate agency behavior. ${ }^{197}$ At the behest of environmental or industry plaintiffs, courts will remand the agency's regulations for further proceedings based on the inadequacy of administrative records prepared under short deadlines. Oversight hearings and the news media will again recount the "administrative horror stories" that result from EPA's strict enforcement of the law. Appropriations riders will seek to prevent such strict application, ${ }^{198}$ while the committees from which the legislation originated will simultaneously draft even more restrictive legislation in response to EPA's "failure." The "spiral of unachievable standards, missed deadlines, resulting citizen suits, and even more prescriptive legislation by Congress continues." 199

\section{B. The Breeding of Controversy}

Regulatory failure was not the only product of the collision between institutional forces surrounding EPA. Considerable controversy also resulted. Indeed, EPA's past twenty years have been marked by persistent allegations of corruption, scandal, and abuse of public trust that have hindered the agency's work.

While arising in a variety of different settings, each of the major controversies involving EPA finds its roots in the operation of the same factors that prompted regulatory failure: (1) competing (and conflicting) efforts to avoid agency capture and (2) the great disparity between the public's aspirations for environmental protection, its understanding of the issues, and its demonstrated (in)capacity to change.

Accusations of improper White House attempts to influence EPA enforcement and improper OMB supervision of EPA originate in the continuing battle between the executive and legislative branches over control of EPA and the direction of national environmental protection policy. ${ }^{200}$ The

197. For example, EPA failed to meet TSCA's deadline for testing of those chemicals nominated by interagency testing commission, which prompted a lawsuit and in turn a court-ordered schedule. See Michael Shapiro, Toxic Substances Policy in Portney, Public Policies at 195, 223 (cited in note 11).

198. See Senate Amendment Would Halt EPA Funding for Controversial RCRA Process, 10 Inside EPA 10 (Oct 6, 1989) (Senate Appropriations Committee approved amendment to end funding for EPA hearing to evaluate whether a state's RCRA authority should be rescinded).

199. Ruckelshaus, 15 Envir $L$ at 463 (cited in note 185). As also described by former EPA Administrator William Ruckelshaus:

The history of events in the $1980 \mathrm{~s}$ is characterized by a singular lack of trust in EPA by

Congress. That is manifested in increasingly prescriptive legislation that strips away administrative discretion from EPA managers and often sets impossible goals for the Agency. These goals may result in political mileage, but their extreme nature ensures practical failure. The result has been missed deadlines, unfulfilled promises of purity, failure to achieve goals, and another round of EPA bashing, followed by even more stringent goals; and the spiral of mistrust continues.

Ruckelshaus, 16 EPA J at 14 (cited in note 167).

200. The same conflict was present in President Nixon's impoundment in 1973, 1974, and 1975 of congressionally appropriated funds for the Federal Water Pollution Control Act's construction grants program. The Supreme Court ultimately ruled against the President in Train v City of New York, 420 US 35 (1975), holding that the impoundment was unlawful. The longer term effect of the confrontation was to galvanize congressional forces in favor of increased oversight of EPA. See NAPA, Oversight Study at 15-16 (cited in note 162). 
tendency was exacerbated by Congress's pretending to have resolved the many difficult conflicts between environmental quality and economic cost about which there was in fact no true social consensus.

The accusations of gross agency incompetence, ignorance, or neglect evident in some of EPA's other misadventures likewise share common origins. EPA's doomed effort to include transportation control plans and indirect source review in state implementation plans under the Clean Air Act resulted from the gulf between public aspirations and public understanding. EPA lawyers were correct that such plans were contemplated by the Act. Their primary error was implementing the Act according to its terms. ${ }^{201}$ Although Congress and state and local officials blamed E.PA for overreaching, the agency can be little faulted for Congress's initial policy determination and the public's subsequent lack of will. ${ }^{202}$ Nonetheless, it was EPA, not Congress, that became the focal point of public criticism. State and local officials widely condemned the agency, and Congress ultimately enacted an appropriations rider that sharply limited EPA's ability to rely on either type of measure. ${ }^{203}$ As described by one commentator, EPA took the fall for Congress and became "every elected official's favorite whipping boy." 204

The allegations of agency neglect arising out of the highly publicized Kepone incident in 1975 and the subsequent resignation of several EPA lawyers from the pesticides program in 1976 can be similarly explained. Federal pesticide legislation, like federal air pollution legislation,

provided EPA with remarkably few 'escape clauses' that allowed the agency to prevent the appearance of outright policy failure. Agency officials, aware that they could not meet statutory deadlines, desperately sought out administrative mechanisms through

201. The Clean Air Act required state implementation plans to include "such other measures as may be necessary to insure attainment and maintenance of such [air quality standards], including, but not limited to, land-use and transportation controls." 42 USC $\$ 1857 \mathrm{c}-5(\mathrm{a})(2)(\mathrm{B})$ (1970). The courts accordingly rejected EPA efforts to delay implementation of the transportation control plans that were necessary to meet the Clean Air Act's air quality standards. See City of Riverside $v$ Ruckelshaus, 4 Envir Rptr Cases (BNA) 1728 (CD Cal 1972); Natural Resources Defense Council, Inc. $v$ $E P A, 475$ F2d 968 (DC Cir 1973).

202. See John Quarles, The Transportation Control Plans-Federal Regulation's Collision with Reality, 2 Harv Envir L Rev 241, 255-62 (1977). "EPA was caught in a crossfire . . between the statutory mandate and the court orders enforcing it on one side and vigorous public opposition on the other. It seems unlikely that any strategy of implementation could have succeeded under such circumstances." Id at 262.

203. See Agriculture-Environmental and Consumer Protection Appropriation Act of 1975, Pub L No 93-563, §510,88 Stat 1822 (1974); Independent Agencies Appropriation Act, Pub L No 94-1 16 , $\S \S 407,89$ Stat 581 (1975). In the Energy Supply and Environmental Coordination Act of 1974 , Congress authorized EPA to suspend for one year its parking management program and its indirect source regulations. See 42 USC $\$ \S 1857 c-5(c)(2)(A)-(E)$ (Supp V 1975); see generally Krier \& Ursin, Pollution and Policy at 229-32 (cited in note 56).

204. Melnick, Regulation and the Courts at 322 (cited in note 8); see Department of Housing and Urban Development and Certain Independent Agencies, Appropriations for Fiscal Year 1987, Hearings before Subcommittee on HUD-Independent Agencies of the House Committee on Appropriations, 99th Cong, 2d Sess 161 (1986) (testimony of Administrator Lee Thomas) ("Everybody is accountable and nobody is accountable under the way [Congress] is setting it up, but they have got a designated whipping boy."). Professor Melnick contends that Congress passed laws that forced EPA to implement transportation control plans; but when EPA acted accordingly, "most members condemned the EPA for its stupidity and arrogance." Melnick, Regulation and the Courts at 378 (cited in note 8 ). 
which they could reach authoritative registration decisions and work out some accommodation with the regulated. ${ }^{205}$

In addition, as in the case of transportation control plans, EPA's early aggressive enforcement of FIFRA, including its cancellation of a number of pesticides, prompted a backlash from those in Congress and the executive branch (including Agriculture) who were more concerned about the cost to industry. ${ }^{206}$ That coalition, in turn, heavily pressured EPA to moderate its enforcement of FIFRA, and Administrator Russell Train ultimately responded by providing the General Counsel's Office, which had initiated the more aggressive approach, less programmatic authority. ${ }^{207}$

When, however, in the aftermath of wide publicity concerning the dangers presented by the pesticide Kepone, concerned agency lawyers aided Senate oversight investigations of agency registration practices, EPA was once again the object of congressional criticism, this time for having neglected its statutory mandate. "The EPA, inundated by its registration and reregistration burdens [under FIFRA], long had abandoned any pretense of systematic data review, blaming their actions on tight resources and unrealistic statutory deadlines." 208 To Senate overseers, however, EPA's consequent reliance on industry data was strong evidence that industry had captured the agency, and that EPA had subverted congressional will at the expense of increased risks to public health. EPA ultimately suspended all registration actions in light of increasing evidence of problems with the industry data upon which EPA had been relying. ${ }^{209}$

Finally, EPA's most controversial era under the leadership of Administrator Anne Gorsuch ${ }^{210}$ can be seen as an expression of institutional conflict and public misapprehension. ${ }^{211}$ The conflict between the executive and legislative branches concerning the proper direction of national environmental policy came to a head with the election of President Reagan. Gorsuch's assignment was to overcome the agency's bureaucracy-which many in the administration believed had been captured by

205. Bosso, Pesticides and Politics at 194 (cited in note 143).

206. Id at 194-95.

207. Id at 195. Congress threatened to transfer some pesticide regulatory authority back to the Department of Agriculture. See 121 Cong Rec 25488-91 (July 28, 1975) (remarks of Rep. Brown); id at 32466 (remarks of Rep. McCloskey); id at 32467 (remarks of Rep. Eckhardt). See Generally id at 32514-19.

208. Bosso, Pesticides and Pollution at 199 (cited in note 143).

209. Id at 199-200.

210. As noted earlier, Anne Gorsuch changed her last name to "Burford" following her marriage in February 1983, which was shortly before she resigned as EPA administrator.

211. This is not to suggest that no corrupt practices occurred during Gorsuch's tenure. There appear to have been instances in which political appointees abdicated their statutory responsibilities for personal pecuniary gain. See Arnold W. Reitze, Jr., Reconsidering Ocean Incineration as Part of a United States Hazardous Waste Management Program: Separating the Rhetoric from the Reality, 17 B C Envir Aff 687, 728-29 nn347-49 (1990). Still, many of the claims of agency corruption were rooted in policy disagreements between the executive and legislative branches. Even classic corruption involving bribery of governmental officials, if it occurred, likely resulted from the quality of appointments made during an administration that devalued EPA's mandate. 
environmentalists ${ }^{212}$-in order to realize the administration's goal of making the environmental laws more cost conscious by administrative rule or, if necessary, by legislative amendment. ${ }^{213}$

But, just as EPA officials had previously overestimated Congress's and the public's willingness to sacrifice on behalf of its aspirations for environmental quality, Gorsuch likewise overestimated public willingness to compromise its aspirations for environmental quality. She also failed to appreciate the significance of those institutional forces within government that historically had been distrustful of EPA, and, as a result, she ultimately became their victim.

Unlike her predecessors, Gorsuch showed no appreciation for the notion of an "independent" EPA, or for the dangers of any appearance of agency capture by the regulated community or by pro-development forces within the government itself. Gorsuch immediately violated the first tenet by occupying an office at the Department of the Interior prior to her confirmation and also by appearing to be carrying out OMB's marching orders. ${ }^{214}$ She violated the second tenet by refusing to take into account how certain actions (appointments, ${ }^{215}$ budget requests, ${ }^{216}$ meetings with industry, ${ }^{217}$ reorganizations, ${ }^{218}$ and rule suspensions ${ }^{219}$ ) and statistics (precipitous drop in

212. Davies, Environmental Institutions at 143, 144 (cited in note 21) ("The Administration was convinced that the regulatory agencies were staffed largely by consumer and environmental 'extremists' who were hostile to Reagan."); Harris, Want \& Ward, Hazardous Waste at 30-31 (cited in note 21 ).

213. Even more broadly, many in the administration, including Gorsuch, "viewed environmental law as an excellent example of the excesses of the past that provided an opportunity to implement the shift back to increased reliance on the free market system and decreased dependence on government intervention." Martin H. Belsky, Environmental Policy Law in the 1980s: Shifting Back the Burden of Proof, 12 Ecol L Q 1, 36-37 (1984).

214. Jonathan Lash, Katharine Gillman \& David Sheridan, A Season of Spoils: The Story of the Reagan Administration's Attack on the Environment 16 (Pantheon, 1984) ("The association with Watt fostered an impression that Anne Gorsuch never completely dispelled, that she was a mere lieutenant in [Watt's] army .... It was a largely erroneous impression, unjust to a strong-willed and opinionated politician, but it shaped expectations for her nevertheless.").

215. Feliciano, EPA: An Analysis of Its Controversies at 7-8 (cited in note 21); Susan Tolchin \& Martin Tolchin, Dismantling America: The Rush to Deregulate 100-01 (Houghton Mifflin, 1983) (describing industry ties of EPA appointees).

216. Under Gorsuch, President Reagan proposed an operating budget for fiscal year 1984 that was one-third less than the agency's operating budget for fiscal year 1981 (President Carter's last EPA budget). See Don Lippincott, Environmental Protection Agency: Ruckelshaus Retums 5 (Harv JFK School of Govt, 1985) (C16-85-638); see also Kenski \& Kenski, Congress Against the President at 99-100 (cited in note 38 ).

217. In a widely publicized meeting on December 11, 1981, Administrator Gorsuch reportedly advised refinery operators that they need not worry about their violation of EPA's leaded gas rules because those rules would soon be changed. See Lash, Gillman \& Sheridan, A Season of Spoils at 140 41 (cited in note 214 ).

218. Gorsuch reorganized the agency's enforcement personnel three times in her first 12 months in office, thereby fueling concerns that she intended to undermine environmental enforcement. See Davies, Environmental Institutions at $148-49$ (cited in note 21).

219. The most notorious rule suspension was EPA's lifting of the ban on disposal of liquid chemicals in hazardous waste landfills that, following tremendous public outcry, EPA reinstated three weeks later. See Feliciano, EP.A: An Analysis of Its Controzersies at 40 (cited in note 21); Lash, Gillman \& Sheridan, A Season of Spoils at 103-04, 119 (cited in note 214). 
enforcement referrals to the Department of Justice) ${ }^{220}$ might be seen as evidence of agency crippling. ${ }^{221}$ Gorsuch, unlike Ruckelshaus before her, ${ }^{222}$ steadfastly maintained that appearances should not matter. ${ }^{223}$ She even eliminated the Office of Public Awareness. ${ }^{224}$

Consequently, regardless of her true motives, ${ }^{225}$ Gorsuch lost any credibility with Congress and the courts almost as soon as her tenure began. The congressional oversight machinery commenced within months of her confirmation and scrutinized for any hint of agency corruption.226 Accusations of "sweetheart deals" with industry, ${ }^{227}$ political manipulation, 228 and agency crippling soon followed. ${ }^{229}$

220. During Gorsuch's first year as administrator, the number of agency referrals dropped by 84\%. See Davies, Environmental Institutions at 148-49 (cited in note 21); Feliciano, EPA: An Analysis of Its Controversies at 19 (cited in note 21 ).

221. Irene Bercovitch Devine, Organizational Crisis and Individual Response: The Case of the Environmental Protection Agency 86-92 (unpub PhD Dissertation, Case W Reserve U, 1983).

222. Marcus, Promise and Performance at 89 (cited in note 11); Quarles, Cleaning Up America at 38-39 (cited in note 123).

223. See, for example, Burford, Are You Tough Enough? at 90 (cited in note 123) ("I viewed the public-relations aspects as something that could wait until we had worked out the bugs. . . . I believed that there was an element of trust involved-that the media would wait until the results of the changes were in before making up their minds about what the reorganization really meant."'); Paul Starobin, Surviving at the EPA: Gary Dietrich 7 (Harv JFK School of Govt, 1984) (C16-84-592) (quoting Gorsuch as rejecting advice to "give [Congress] the sense that you have your heart in the right place" based on her refusal to "kow-tow to [Representative] Jim Florio").

224. See Douglas Murray, The Politics of Pesticides: Corporate Power and Popular Struggle over the Regulatory Process 206 (unpub PhD dissertation, U Cal Santa Cruz, 1983).

225. The former administrator maintains that she had no intention of undermining the agency's effectiveness and sought instead to improve its efficiency and effectiveness in delivering environmental protection and quality. See Burford, Are You Tough Enough? at 65 (cited in note 123). This is a difficult burden for Gorsuch to carry. It likely depends for its ultimate justification on the thesis that the states are in a better and more appropriate position to do much of what EPA has historically done. If so, then the claim that Gorsuch and her staff sought to dismantle EPA as we know it would seem close to the mark.

226. In 1981, the chairs of six different committees and subcommittees began to investigate EPA under Gorsuch, including the Senate Committee on Environment and Public Works (Sen Robert T. Stafford, Vermont); Subcommittee on Health and the Environment (Rep. Henry A. Waxman, California) of the House Committee on Energy and Commerce; Subcommittee on Commerce, Transportation, and Tourism (Rep. J. Florio, New Jersey) of the House Committee on Energy and Commerce; Subcommittee on Environment, Energy and Natural Resources (Rep. Tony Moffett, Connecticut) of the House Committee on Government Operations; Subcommittee on Investigations and Oversight (Rep. Albert Gore, Tennessee) of the House Committee on Science and Technology; and Subcommittee on Natural Resources, Agriculture Research, and Environment (Rep. James H. Scheuer, New York) of the House Committee on Science and Technology; see also EPA Oversight: One-Year Review, Joint Hearings before Certain Subcommittees of the House Committee on Government Operations, House Committee on Energy and Commerce, and the House Committee on Science and Technology, 97th Cong, 2d Sess 1 (1982).

227. Note, The Conflict Between Executive Privilege and Congressional Oversight: The Gorsuch Controversy, 1983 Duke L. J 1333, 1341 n59 (authored by Ronald L. Claveloux); Feliciano, EPA: An Analysis of Its Controversies at 32 (cited in note 21 ).

228. See Feliciano, EPA: An Analysis of Its Controversies at 34, 35-38 (cited in note 21); see also Howard Kurtz, Political Races Discussed with Superfund Chief, Washington Post A1 col 6 (March 22, 1983).

229. See Lawrence Mosher, Move Over Jim Watt, Anne Gorsuch Is The Latest Target of Environmentalists, 13 Natl J 1899 (Oct 1981); Devine, Organizational Crisis at 92 (cited in note 221). No doubt the single most harmful statement was that contained in an op-ed piece written by former EPA Administrator Russell E. Train. See Russell E. Train, The Destruction of EPA, Washington Post Al5 (Feb 2, 1982) 
Moreover, when Gorsuch finally took steps to address adverse congressional and public perceptions of her motives, she did so at the expense of her relationship with $\mathrm{OMB},{ }^{230}$ thereby cutting off her last source of political support. ${ }^{231}$ Even the regulated community, which welcomed the administration's philosophy of deregulation, could no longer afford the instability that she created. ${ }^{232}$ Ironically, the final event that triggered her departure-an assertion of executive privilege in declining to provide Congress with agency enforcement files-was, as she claimed, not one of her making. ${ }^{233}$ But her loss of credibility by then was so great that there was no one left to listen or care.

Gorsuch's tenure as EPA administrator (a few months shy of two years) was shorter than that of any other administrator before or since. The effects on the institutional development of EPA and the evolution of federal environmental law have lasted far longer. She confirmed the worst fears of those in Congress who were concerned about the agency's potential for deliberately undermining the federal environmental protection laws. She thus dramatically accelerated the cycle of distrust that had plagued EPA before her arrival, prompting one commentator to conclude that "the most poignant and irremediable [impact] was the EPA's loss of credibility; the loss of credibility with the Congress and, more importantly, with the American people."'234

\section{IV \\ The Tragedy of Distrust: \\ The Stifling of Environmental Protection}

EPA is plainly in a dilemma. The agency strives to be responsive to both the environmentalists' vision and the regulated community's pragmatism, but

\footnotetext{
("The budget and personnel cuts, unless reversed, will destroy the agency as an effective institution for many years to come."); Lash. Gillman \& Sheridan, A Season of Spoils at 61 (cited in note 214).

230. Lash, Gillman \& Sheridan, A Season of Spoils at 57-59, 72 (cited in note 214).

231. Davies, Environmental Institutions at 154-55, $156-57$ (cited in note 21 ).

232. Id at 157; see also Stanfield, $18 \mathrm{Natl} \mathrm{L}$ J at 392 (cited in note 124). Those among the regulated who had already made the investments necessary to comply with EPA rules were not likely to favor relaxation that would provide their competitors with an economic advantage. See Foreman, Signals from the Hill at 37 (cited in note 36 ).

233. Career staff at the Department of Justice instigated the refusal to turn over enforcement files because of their concerns with congressional access. See HR Rep No 99-435, 99th Cong, 1 st Sess 10 (1985) (report on Department of Justice role in withholding of EPA documents from Congress); Milan Savarous Yancy, An Evaluation of the Initial Implementation of the Comprehensive Environmental Response, Compensation, and Liability Act of 1980: The Effect of the Witholding of Documents by the Environmental Protection . Agency from Congress in 1982-83, at 76 (unpub PhD dissertation. U Texas Dallas, 1988) ("CERCLA Evaluation"); see generally Shane, 71 Minn L Rev at 508-16 (cited in note 177); Note, 1983 Duke LJ 1383 (cited in note 227). Representative Dingell, who was one of Gorsuch's principal investigators. reportedly stated upon learning of her resignation: "I see no reason why she should resign. I'm aware of no wrongdoing on her part that should compel that. She is taking the fall for carrying out clearly what are the administration's policies." Feliciano, EP.4: An Analysis of Its Controversies at 2 (cited in note 21), quoting Paula Schwed, UPI report (March 10, 1983).

234. Yancy, CERCL.t Eialuation at 123 (cited in note 233); sce Davies, Envirommental Institutions at 158 (cite in note 21 ) ( $[A]$ tamished reputation takes a long lime to restore.")
} 
ultimately satisfies neither. ${ }^{235}$ EPA is also a pawn in an ongoing struggle between the executive and legislative branches for control over national policy. ${ }^{236}$ Finally, EPA is pushed in one direction by public aspirations and pulled in the other direction by the absence of public willingness to change and by the public's proven incapacity for self-sacrifice. ${ }^{237}$

To be sure, EPA is itself responsible for some of its failures and for the generation of some of its controversies; it is not solely a victim of historical and institutional circumstances. As with other federal agencies, there have been many instances of mismanagement and poor decisionmaking for which agency officials deserve to be held accountable. But placed in proper perspective, most of EPA's reported failures and controversies seem more justly viewed as the product of institutional conflict and public schizophrenia than as the result of systemic EPA dereliction or incompetence. ${ }^{238}$

EPA's dilemma could nonetheless be viewed positively as a small price to pay in the United States' first effort to reshape its relationship with its natural environment. Certainly this nation's accomplishments in seeking to produce a legal regime for environmental protection have been extraordinary. In relatively few years, the nation's laws have been dramatically rewritten. Viewed from this perspective, repeated regulatory failure could be seen as the necessary cost of our attempt to address pressing environmental problems in the face of scientific uncertainty. There was not sufficient time to delay governmental action until its environmental objectives could have been fairly and accurately defined. ${ }^{239}$

The conflict and controversy surrounding EPA during the last twenty years could be similarly viewed as a necessary evil, as the inevitable consequence of

235. As described by former EPA Administrator Russell Train, "[i]f a decision doesn't go as far as our environmental friends would like, it is immediately called a sellout. If the decision goes against industry, we're accused of giving into [sic] environmental emotionalism." Quoted in Alfred A. Marcus, EPA's Successes and Failures, in Kamieniecki, O'Brien \& Clarke, eds, Controversies in Environmental Policy at 168 (cited in note 84); see CEQ Sixteenth Annual Report at 2-3 (cited in note 53); Michael McCloskey, The Crisis of Failing Bureaucracies, 27 Nat Resources J 243, 243-44 (1987) ("The career civil service is caught in relentless cross-fire between industry and environmentalists. This tends to bring things to a halt easily, with the 'out' being to study issues endlessly in a quest for a scientific certainty that will stand up to anybody's scrutiny.").

236. Id; Bruce Ackerman \& William Hassler, Clean Coal, Dirty Air 110 (Yale U Press, 1981).

237. CEQ Sixteenth Annual Report at 16 (cited in note 53) ("Political forces cause stringent scliedules and ambitious goals to be written into law, ... but due to logical consequences of implementation, some programs become politically unfeasible."); Helen Ingram \& Dean E. Mann, Environmental Policy: From Innovation to Implementation, in Theodore J. Lowi \& Alan Stone, eds, Nationalizing Government 132 (Sage, 1978).

238. See Commission on Natl Resources/Natl Res Council, Analytical Studies for the U.S. Environmental Protection Agency, in Natl Res Council, 2 Decisionmaking in the Environmental Protection Agency at 2 (cited in note 97) ("[W] $]$ hen specific criticisms of EPA decision making are traced to their roots, the problems more frequently are seen to derive from the stringent directives of the environmental statutes than from faulty administrative action."): Robert L. Rabin, l'ieuing the Administrative Process First-Hand, Thoughts on a lear's Leave at EPA, 15 Stan Lawyer 19 (Fall/Winter 1980): Note, The Political Economy of Superfund Implementation, 59 S Cal L Rev 875, 899-900 (1986) (authored by James R. Buckley).

239. See EESI, Statulon' Deadlines at 43 (cited in note 49) ("Statutory deadlines are unavoidably unrealistic . . because Congress is often trying to force action in a new area. and no one knows what it's going to take to get the job done."). 
administrative agency implementation of fundamental social change in our system of government, which heavily depends on the actions of each branch being overseen by the others. Isolated excesses may have resulted, and there may have been cases of overreaching, but the advantages of intense oversight have been overwhelming.

For instance, the impossible objectives and unrealistic deadlines contained in "symbolic" environmental legislation place EPA in an administrative quandary, but they also effectively send a public message concerning the urgency and seriousness of environmental problems. ${ }^{240}$ Such objectives and deadlines also provide the environmental community, which has fewer resources, with an effective rhetorical advantage in its debate with the regulated community concerning the need for environmental protection. ${ }^{241}$

Close judicial and congressional scrutiny of EPA has clearly also had significant benefits. It is likely that an active judiciary improved the quality of EPA decisionmaking in some cases. ${ }^{242}$ And, as was the case in Congress's exposure of EPA's initial mishandling of the Superfund program, persistent congressional examination of EPA can be credited for having revealed instances of agency neglect and corruption and of OMB overreaching. ${ }^{243}$ Certainly the threat of both judicial and congressional oversight enhanced EPA's leverage in resisting competing forces within the executive branch. ${ }^{244}$

There is also some advantage to the public in the way environmental laws have evolved in response to repeated agency failure. The statutes allow for less agency discretion while arguably reflecting greater congressional assumption of responsibility for making public policy. Congress was faulted

240. Richard B. Stewart, The Development of Administrative and Quasi-Constitutional Law in Judicial Review of Environmental Decisionmaking: Lessons from the Clean Air Act, 62 Iowa L Rev 713, 727 (1977).

241. See R. Shep Melnick, Pollution Deadlines and the Coalition for Failure, 75 The Public Interest 132 (Spring 1984).

242. William F. Pedersen, Jr., Formal Records and Informal Rulemaking, 85 Yale L J 38, 59-60 n87 (1975); Stewart, 62 Iowa L Rev at 731-32 n89 (cited in note 240); Cass R. Sunstein, On the Costs and Benefits of Aggressive Judicial Review of Agency Action, 1989 Duke L J 522, 528-29, 537 ("[T] basis for believing that aggressive judicial review has, in many settings, increased the incidence of legality, prevented arbitrariness, ensured against undesirable regulation, and brought about regulatory controls that have saved lives or otherwise accomplished considerable good."). There are also weighty reasons for the judiciary to be especially concerned about the validity of environmentally destructive activities; for instance, those who may be adversely affected by environmental degradation are (as in the case of future generations) often unable to voice their concerns effectively in court. See Richard J. Lazarus, Changing Conceptions of Property and Sovereignty in Natural Resources: Questioning the Public Trust Doctrine, 71 Iowa L Rev 631, 684-85 n336 (1986) ("[D]ozens of opinions recount the language of the National Environmental Policy Act ("NEPA") concerning protection of the rights of 'succeeding generations' to a healthy environment."); Glicksman \& Schroeder, 54 L \& Contemp Probs at 271-72 (cited in note 39).

243. See, for example, Leslie Maitland, Top E.P.A. Official is Accused of Intervening in Behalf of Company, NY Times B 13 (March 24, 1983); Philip Shabecoff, Budget Offire Attacked over Rules for Asbestos, NY Times A32 col 1 (Oct 3, 1985); see also Landy, Roberts \& Thomas, EPA: Asking the Wrong Questions at 113 (cited in note 32); see also West \& Cooper, 104 Pol Sci Q at 606 (cited in note 164) (active role for Congress in administrative process is "salutary" and "political representation brought to bear through legislative oversight is a healthy counterpose to that introduced by executive oversight").

244. See Melnick, Regulation and the Courts at 293-94 (cited in note 8); Quarles, Cleaning lip America at 132, 136 (cited in note 123). Deadlines also increase an EPA manager's power to bargain for resources within the agency. See EESI, Statutory Deadlines at 27 (cited in note 49). 
for unfairly (and improperly) passing the buck to EPA in the environmental statutes of the $1970 \mathrm{~s}^{245}$ In the more prescriptive environmental statutes, Congress is now making many of the difficult policy determinations necessary to fashion environmental quality standards. ${ }^{246}$

Finally, there is even a positive way to view public distrust of EPA. After all, "political distrust has been a recurrent and perhaps a permanent feature of the history of the republic." 247 Effective democracy undoubtedly requires criticism of government based on mistrust of its institutions. ${ }^{248}$ Certainly, much of the federal constitution is designed to protect individuals from governmental overreaching, ${ }^{249}$ just as separation of powers principles are intended to prevent overreaching by any one branch of government.

Appreciation of the benefits of the current institutional regime does not, however, mean that its adverse effects are insubstantial. Nor does it mean that significant reform is unnecessary. Celebration of past achievement is no substitute for careful planning for the future. This is certainly true for environmental law. There is a growing consensus that fundamental changes in approach will be necessary for the country to reach acceptable levels of environmental protection while maintaining a high standard of living. ${ }^{250} \mathrm{~A}$ detailed accounting of the ways in which existing institutional forces have impeded federal environmental protection efforts over the last twenty years strongly suggests, moreover, that institutional reform will be required for such fundamental change to be achieved.

\section{A. Loss of Public Confidence and Agency Self-Esteem}

Included among the most immediate and persistent impacts of the current institutional scheme are loss of public confidence in EPA and loss of the agency's confidence in itself. EPA's repeated regulatory failures and frequent controversies created a public image of an incompetent, neglectful, and at

245. Schoenbrod, 30 UCLA L Rev at 818-26 (cited in note 37).

246. Of course, Congress clearly learns from EPA's experience in legislating detailed rules and often codifies the agency's past practice. For example, the Clean Water Act's regulatory approach to toxic pollutants, 33 USC $\$ 131$ l(1) (1988), the Clean Air Act's approach to Prevention of Significant Deterioration, 42 USC $\S \S 7470-7479$ (1988), and CERCLA's approach to settlement, 42 USC $\$ 9622$ (1988), each largely reflects past administrative practice. See Dwyer, $17 \mathrm{Ecol} \mathrm{L} Q$ at $310 \mathrm{n} 315$ (cited in note 46); Melnick, Regulation and the Courts at 50-51, 86, 188 (cited in note 8).

247. Vivien Hart, Distrust and Democracy: Political Distrust in Britain and America 81 (Cambridge U Press, 1978); see Bernard Barber, The Logic and Limits of Trust 71 (Rutgers U Press, 1983); House Committee on the Post Office and Civil Service, Report and Recommendations of the National Commission on Public Service 79 (Comm Print, 1989) ("Committee Report").

248. See Barber, The Logic and Limits of Trust at 166 (cited in note 247) (Rationally based distrust of technical competence is necessary "for political accountability in a participatory democracy."); Hart, Distrust and Democracy at 183-92, 202-08 (cited in note 247) (Distrust "is the product of the public's realistic and accurate perception of deficiencies."); Seymour Martin Lipset \& William Schneider, The Confidence Gap 383 (The Free Press, 1983).

249. Rosen, Holding Government Bureaucracies Accountable at 15 (cited in note 134).

250. See generally Bruce A. Ackerman \& Richard B. Stewart, Reforming Entironmental Law. 37 Stan L Rev 1333 (1985); Adam Babich, Restructuring Environmental Law, 19 Envir L Rptr 1005 (Feb 1989); Reilly, The Tuming Point (cited in note 51); Arnold W. Reitze, Jr., Environmental Policy-lt is Time for a New Beginning, 14 Colum J Envir L 111 (1989); EPA Science Advisory Board, Reducing Risk: Setting Priorities and Strategies for Environmental Protection (Sept 1990) (“EPA, Reducing Risk"). 
times even corrupt agency. ${ }^{251}$ A myth of scientific incompetence resulted, ${ }^{252}$ which EPA can ill afford, but which others may have an incentive to perpetuate. ${ }^{253}$

The level of distrust in EPA, moreover, is inconsistent with the needs of an administrative agency responsible for the implementation of federal environmental laws. An important lesson of the last twenty years is that EPA simply cannot do its job effectively without greater public confidence in the agency. ${ }^{254}$ EPA cannot effectively manage public risk without the confidence of the public any more than a doctor could treat a patient without that patient's trust. ${ }^{255}$ " [F]rom the standpoint of an American governmental agency charged with protecting human health and the environment, trust is

251. See, for example, Douglas Frantz, Polluters Put in Charge of Cleaning Up: The Environmental Protection Agency Is Accused of Abdicating Its Responsibilities and Sacrificing Public Heallh. Evidence Shows Private Labs Have Falsified Tests, LA Times A1 col 1 (June 17, 1990); see generally Dwyer, 17 Ecol L Q at 281 (cited in note 46) ("By making promises that cannot be kept, and thus forcing EPA to reformulate public policy, Congress indirectly undermined public confidence in the Agency's competence and good faith."); Melnick, Regulation and the Courts at 383-87 (cited in note 8) (current way of setting policy "increases cynicism and distrust of government"); Charles J. Meyers, Comment, in Ann F. Friedlaender, Approaches to Controlling Air Pollution 67 (MIT Press, 1978) ("The cost is not just the waste of resources but is also the loss in confidence in government-and in ourselves."). In 1972, Administrator Ruckelshaus cautioned Congress against promoting the very loss of public confidence in EPA that subsequently developed. In oversight hearings, he testified that the "tragedy" in 1972 was that the public does not trust its institutions and people "don't believe that the EPA is really trying to protect the environment." See Implementation of the Clean Air Act of 1970 at 325 (cited in note 123) (testimony of Administrator Ruckelshaus). According to Ruckelshaus, accusations of improper OMB influence on EPA, made in the oversight hearing, could be used "to feed this mistrust" and undermine the dedication of EPA employees "and their ability to function as public employees." Id at 325, 328. This is what Ruckelshaus found "most distressing about the constant charges that are made." Id at 328.

252. See Ted Greenwood, The Myth of Scientific Incompetence of Regulatory Agencies, Sci, Tech \& Human Values 83 (Winter 1984).

253. Id at 95 ("To argue that an agency is incompetent... is to raise an issue that both commands attention and erodes the agency's authority and legitimacy.").

254. Nominations of Douglas Costle and Barbara Blum, Hearing before the Senate Committee on Environment and Public Works, 95th Cong, lst Sess 14 (1977) (testimony of Douglas Costle) ("Full public support and understanding is essential if we are to do our job."); Nomination of Lee M. Thomas, Hearing before the Senate Committee on Environment and Public Works, 99th Cong, 1st Sess 5 (1985); Ruckelshaus, 16 EPA J at 14, 15 (cited in note 167) ("Both public trust and a selfconfident EPA are necessary ingredients for true environmental progress."); Nomination of William Ruckelshaus at 5 (cited in note 35) (testimony of Dr. Jay D. Hair, executive vice president, Natl Wildlife Federation); id at 200 (testimony of William Ruckelshaus: "If the public does not believe that what we are doing is in their best interest, that we are trying the very best we can to deal with these problems, then there is no way this Agency can function."); see also Department of Housing and Urban Development, Independent Agencies Appropriations for 1976, Hearings before a Subcommittee of the House Committee on Appropriations, 94th Cong, 1st Sess Part 6, 77 (1975) (testimony of Administrator Train. "It is important that EPA be perceived . . by society as a whole as a strong advocate of environmental protection."); Department of Housing and Urban Development, and Certain Independent Agencies, Appropriations for Fiscal Year 1985, Hearings before a Subcommittee of the Senate Committee on Appropriations, 98th Cong, 2d Sess Pt I, 294 (1984) (testimony of Administrator Ruckelshaus).

255. Thomas O. McGarity, Risk and Trust: The Role of Regulatony Agencies, 16 Envir L Rptr 10198, 10200-01 (1986); Ruckelshaus, 15 Envir L at 461 (cited in note 185) ("necessity of trust between the EPA and the public in areas of scientific uncertainty... especially where public emotion runs high, such as with carcinogenic chemicals"); Bud Ward, Communicating on Environmental Risk, The Envir Forum 4 (Jan 1986); Joel Yellin, Science, Technolog;, and Administrative Gozernment: Institutional Designs for Environmental Decisionmaking, 92 Yale L J 1300, 1324 (1983) ("Clarity and fullness of explanation are central to the legitimacy of decisions affecting individual health and safety."); sce also Barber, The 
the oil in the gearbox.... [W] hen [the public] ceases to believe that the agency is trying to act in the public interest, that agency cannot function at all."'256

EPA's lack of credibility has, for instance, severely hampered the agency's ability to manage the Superfund program. Based on his review of the Superfund program, EPA's current administrator, William Reilly, concluded that "the legacy of public distrust" surrounding EPA's management of the program and "the barrage of criticism leveled at the program nationally" had caused the agency to lose its "most valuable asset, the benefit of the doubt." 257 When the public's unrealistic expectations of quick cleanup were not met, Reilly concluded, the public became suspicious of federal efforts and unwilling "to completely trust EPA to represent them in confidential negotiations with [potentially responsible parties]." 258 As a result, cleanup efforts were slowed. ${ }^{259}$

More broadly, the absence of public confidence has exacerbated the gap between the public's and the agency's perception of risk, undermining the validity of the agency's efforts to manage risk. EPA's Science Advisory Board recently concluded that "the remaining and emerging environmental risks considered most serious by the general public today are different from those considered most serious by the technical professionals charged with reducing environmental risk."260 Not only does the public fail to accept EPA's assessment of the relative risks of various hazards, but EPA, too, fails to appreciate the public's distinct assessment. EPA discounts the public's risk perception as a product of ignorance and misunderstanding. Because risk assessment is, however, at bottom, not simply a technical determination, but "an ethical and political one that technical experts have neither the knowledge nor the authority to dictate,"261 EPA's technical approach may systematically fail in cases of diffuse, low probability risks. ${ }^{262}$

Logic and Limits of Trust at 141 (cited in note 247) (public generally has great trust in competence of doctor).

256. William D. Ruckelshaus, "Not in My Backyard": Institutional Problems in Environmental Protection (speech before Economic Club of Detroit, April 1984), reprinted in 130 Cong Rec 9803 04 (1984).

257. William K. Reilly, A Management Review of the Superfund Program 2, 5-4 (EPA, 1989).

258. Id at 5-1 to 5-4; see McGarity, 16 Envir L Rep at 18 (cited in note 255) (accusations of sweetheart deals).

259. EPA's current assistant administrator for pesticides and toxic substances recently commented that EPA's lack of credibility with the public had impeded the agency's ability to communicate the risks associated with the preservative ALAR and had prompted great conflict over its plan to ban asbestos. See New OPTS Chief Will Seek Expanded TSCA Authority, Legislative Fixes to FIFRA, 10 Inside EPA 1, 7-8 (Oct 6, 1989); see also Christine Russell, A Crisis in Public Confidence, 16 EPA J 2, 4-5 (May/June 1990). Similar problems arose at an earlier time involving EPA's handling of public concern with ethylene dibromide ("EDB"), when a "tidal wave of public anxiety swept the country." See Harold Issadore Sharlin, EDB: A Case Study in the Communication of Health Risk 2 (Jan 9, 1985) (report prepared for Derry Allen, associate director, EPA Office of Policy Analysis).

260. EPA Science Advisory Board, Reducing Risk at 12 (cited in note 250).

261. Clayton P. Gillette \& James E. Krier, Risk, Courts, and Agencies, 138 U Pa L Rev 1027, 1085 (1990).

262. Id at 1085. Professors Gillette and Krier argue that agencies have "a systematic tendency in favor of too much public risk," id at 1061, because producers of public risk "will generally enjoy a 
Finally, the loss of public confidence in EPA has at times caused the agency to lose confidence in itself, as well as causing a general decline in agency selfesteem. The morale and self-esteem of a bureaucracy can be severely damaged by sustained public criticism. ${ }^{263}$ Agency self-confidence is likewise adversely affected by increasingly prescriptive statutes and intense oversight. ${ }^{264}$ The adverse effects of agency demoralization are particularly acute in an agency such as EPA whose employees choose to work there primarily out of their sense of sharing in the agency's perceived mission rather than for more tangible rewards. ${ }^{265}$ Agency turnover becomes greater as employees are increasingly deprived of the sense of public service they sought in government employment. ${ }^{266}$ For this same reason, recruitment of the very best employees becomes more difficult.

EPA is suffering from all of these problems. Indeed, the adverse effects may be especially acute for agency technical staff whose salaries have historically been much lower than those of their legal counterparts within the agency. The low salary scale and reduced agency self-esteem have made it difficult to attract such technical employees and, even more so, to retain them. As a result, EPA is losing the sustained technical expertise it needs most to address long-term environmental problems. ${ }^{267}$

considerable comparative advantage in mobilizing interest groups and exercising influence, whether by benign or sinister means." Id at 1068. According to Gillette and Krier, however, judges and juries are better able to redress public conception of risk precisely because they are "not experts." Id at 1101 (emphasis in original).

263. Freedman, Crisis and Legitimacy at 40 (cited in note 45).

264. Steven Kelman, Making Public Policy: A Hopeful View of American Government 294 (Basic Books, 1987); Department of Housing and Urban Development-Independent Agencies Appropriations for Fiscal Year 1980, Hearings before the Subcommittee on HUD-Independent Agencies of the House Appropriations Committee, 96th Cong, 1st Sess 243 (1979) (testimony of Administrator Douglas Costle; OMB oversight adversely affects agency morale); Department of Housing and Urban Development and Certain Other Independent Agencies Appropriations for Fiscal Year 1979, Subcommittee of the Senate Committee on Appropriations, 95th Cong, 2d Sess 502 (1978) (testimony of Administrator Douglas Costle; EPA's high turnover rate a product of congressional deadlines); Implementation of the Clean Air Act of 1970 at 328 (cited in note 123) (testimony of Administrator William Ruckelshaus; accusations undermine employee "dedication" and "ability to function as public employees").

265. See Devine, Organizational Crisis at 71 (cited in note 221); Kelman, Making Public Policy at 247, 261-62 (cited in note 264); Steps Toward A Stable Future 3 (Natl Acad Pub Admin, 1984); see also Wilson, Bureaucracy at 95 (cited in note 16) ("sense of mission confers a feeling of special worth on the members, provides a basis for recruiting and socializing new members and enables the administrators to economize on the use of other incentives").

266. See Devine, Organizational Crisis at 90-91 (cited in note 221); Committee Report at 84-85 (cited in note 247).

267. EPA clearly lost a significant amount of agency expertise by the exodus of career staff during Administrator Gorsuch's tenure. See Lash, Gillman \& Sheridan, $A$ Season of Spoils at 62 (cited in note 214); Surviving at the EPA: Mike Cook (Harv JFK School of Govt, 1984) (C16-84-590); Surviving at the EPA: Mike Walsh (Harv JFK School of Govi, 1984,) (C16-84-589); Surviving at the EPA: David Tunderman (Harv JFK School of Govt, 1984) (C16-84-588); Yancy, CERCLA Evaluation at 121-22 (cited in note 233); Devine, Organizational Crisis at 119 (cited in note 221) (54\% of EPA employees questioned in 1982 said they would make a genuine effort to look for new employment outside the federal government within following year.). There are indications that a high turnover rate persists. See Nomination of William K. Reilly at 108 (cited in note 35); Dingell Probes Effects of Indoor Air Pollution on Morale. Tumover, 11 Inside EPA 7 (July 27, 1990); EPA L'nveils RCRA Overhaul Plan: Set Priorities, Reward Staff to Curb Tumover, 11 Inside EPA i-2 (July 13, 1990). 


\section{B. Polarization of Debate and Proliferation of Litigation}

Another significant adverse effect of the current scheme is its tendency to polarize the debate on environmental issues and to encourage litigation. Environmentalists, the regulated community, Congress, and even EPA repeatedly rely on extreme allegations in seeking public support for their respective positions. There is little, if any, candid dialogue. As one commentator put it, symbolic legislation such as the Clean Air Act of 1970 "infantilized rather than matured public opinion."'268

Moreover, by making impossible demands and attacking EPA for any compromise, environmentalists have "discouraged EPA from being honest with the public." 269 Nor has EPA hesitated to use its own scare tactics to shift public opinion in its favor. In 1980, for example, the agency systematically exaggerated the relative hazards presented by abandoned hazardous waste sites in order to increase public pressure on Congress to pass CERCLA. ${ }^{270}$

One harmful result of such issue polarization is excessive reliance on litigation to resolve conflicts. Indeed, agency decisionmaking becomes a mere prelude to litigation. ${ }^{271}$ The rulemaking proceedings tend to be adversarial; the competing sides exaggerate or minimize the relative risks, suppress relevant information, and distort scientific data. ${ }^{272}$ Agency lawyers consequently take on more responsibility in the preparation of agency decisions at the expense of other agency professionals. ${ }^{273}$ The dividing line between legal advice and policy advice becomes blurred, and, as a result,

268. Schoenbrod, 30 UCLA L Rev at 819 (cited in note 37); see Dwyer, 17 Ecol L Q at 234 (cited in note 46 ).

269. Landy, Roberts \& Thomas, EPA: Asking the Wrong Questions at 126 (cited in note 32).

270. Id at 279-80; see id at 167 ("For EPA to have conceived of its duty in a manner more conducive to the enhancement of public education and political responsibility, it needed to be part of a larger political system in which statesmanship, not salesmanship, was the mark of a good agency executive."). Another illustration of the problem with polarization is presented by the controversy surrounding EPA's refusal to provide Congress with access to its enforcement files. See note 233. Although the confrontation with Congress ultimately led to Anne Gorsuch's resignation, lost in the uproar was any meaningful discussion of the merits of the executive branch's legal position. The files may well have contained documents, the release of which might have been harmful to ongoing enforcement efforts. One can therefore well imagine why career lawyers at the Justice Department were concerned about the release of these documents to congressional staff, some of whom might have had industry ties. See Note, 1983 Duke L J at 1348-49 (cited in note 227).

271. Wilson, Bureaucracy at 283-84 (cited in note 16).

272. Natl Res Council, Decisionmaking at 79.81 (cited in note 97) (recommendation with reasons that there be reduced reliance on trial-type procedures); Bryner, Bureaucratic Discretion at 114-15 (cited in note 37); Thomas O. McGarity, The Internal Structure of EPA Rulemaking, 54 L \& Contemp Probs 57, 99-102 (Autumn 1991); see also Administrative Law Symposium: Question EO Answer with Professors Elliott, Strauss, and Sunstein, 1989 Duke L J 551, 557 (remarks of Professor Don Elliott, questioning efficacy of "overjudicialization of the regulatory process and the concomitance of lawyers in policymaking positions within agencies").

273. J. William Hirzy, The Other Voice from EPA: The Role of the Headquarters Professionals ' Imion, 20 Envir L Rptr 10057 (1990) ("The science element of EPA became not only subordinate but also subservient to the legal element."); Melnick, Regulation and the Courts at 341 (cited in note 8); Wilson, Bureaucracy at 284 (cited in note 16); see also Ashley C. Brown, The Overjudicialization of the Regulatory Process, 5 Natl Resources \& Envir 20, 22 (Fall 1990). Agency lawyers are also reputed to be more adversarial and litigation oriented than other agency professionals. See Wilson, Bureaucracy at 60 (cited in note 16 ). 
lawyers in the EPA General Counsel's Office have become increasingly influential on matters of agency policy. ${ }^{274}$ Internal agency meetings also become more adversarial, with published agency decision documents tending to resemble legal briefs rather than candid presentations of the competing arguments. ${ }^{275}$ Technical expertise is devalued, and opportunities for public education are missed. 276

\section{Wasted Resources and Misdirected Priorities}

The legacy of distrust created by the current institutional scheme also creates tremendous delay and poorly allocates the limited agency resources among competing priorities. The combination of impossible statutory mandates and increased judicial access has created a situation in which more than 80 . percent of EPA's major decisions are finally decided by formal negotiated settlement or court decision. ${ }^{277}$ EPA officials are compelled to spend as much as 90 percent of their time defending their actions in court and in congressional hearings. ${ }^{278}$ They are left little time to make thoughtful, considered determinations ${ }^{279}$ and are forced to spend excessive time on a few issues in order to satisfy the various overseers. ${ }^{280}$ There is accordingly little,

274. EPA, Program at a Crossroads at 34 (cited in note 110).

275. Landy, Roberts \& Thomas, EPA: Asking the Wrong Questions at 283-84 (cited in note 32 ) (EPA decisionmaking becomes battle for "turf" between different decisionmaking units; agency lawyers are preoccupied with anticipated litigation rather than with public education); see id at 78-82 (EPA determination of ozone standard failed to educate the public about difficulty of the issues because it became an adversarial process between competing bureaucrats); Melnick, Regulation and the Courts at 40-41,382-83 (cited in note 8) (describing conflict between agency lawyers and technical specialists in implementing the Clean Air Act); Ackerman \& Hassler, Clean Coal, Dirty Air at 79-86 (cited in note 236) ("agency at war with itself").

276. Compare E. Donald Elliott, The Future of Toxic Torts: Of Chemophobia, Risk as Compensable Injury and Hybrid Compensation Systems, 25 Houston L Rev 781, 797 (1988) ("If the American people are ever going to have a more informed, mature, and balanced attitude toward the risks of chemicals in the environment, toxic tort litigation, like other forms of our public discourse, must educate the public, and not pander to its fears and prejudices." ).

277. Ruckelshaus, 15 Envir L at 463 (cited in note 185); see Bryner, Bureaucratic Discretion at 39 (cited in note 37 ).

278. NAPA, Oversight Study at 27 (cited in note 162) (Milton Russell, former EPA assistant administrator for policy and planning, stat ad that "oversight and litigation drive 90 percent of the agency's priorities, and there is very little opportunity to do anything else."); see id at 28 (former EPA Deputy Administrator James Barnes said, "It wouldn't surprise me to find there are four people doing oversight, for every one doing the job to begin with.").

279. Landy, Roberts \& Thomas, EPA: Asking the Wrong Questions at $111-12$ (cited in note 32) (congressional oversight diverted agency resources from developing RCRA regulations); see also Foreman, Signals from the Hill at 4 (cited in note 36) (subcommittee ties with administrative agencies are so strong, and committee meddling in administrative and policy detail so pervasive and unpredictable, that coordinated, responsible governance is not much of a prospect).

280. See Alden F. Abbot, The Case Against Federal Statutory and Judicial Deadlines: A Cost-Benefit Approach, 39 Admin L Rev 171, 186-200 (1987); Douglas M. Costle, Brave New Chemical: The Future Regulatory History of Phlogiston, 33 Admin L Rev 195, 199-201 (1981) (describes delays associated with promulgation of rule regarding imaginary chemical and discusses how, under FIFRA, EPA's process for canceling a single pesticide can take two to three years); Michael Arnold Berry, A Method for Examining Policy Implementation: A Study of Decisionmaking for the National Ambient Air Quality Standards, 1964-84, 215-26 (1984) (unpub PhD dissertation, U of N C at Chapel Hill, 1984) (discussing great delay in EPA decisionmaking because of threat of congressional and judicial oversight); see also Note, 1 Fordham Envir L J at 65 (cited in note 77) (impact of deadline on agency ability to address other problems). 
if any, time left to respond to internal agency demands. ${ }^{281}$ Indeed, congressional oversight of EPA has periodically been so intense that the agency has been effectively paralyzed as a result. ${ }^{282}$ Ironically, therefore, much of the delay about which Congress complains may be the product of its own oversight of the agency. ${ }^{283}$

Another adverse effect of excessive oversight of EPA is that it has caused the agency to go "underground" in its lawmaking. To avoid overseers, EPA has increasingly resorted to less formal means of announcing agency policy determinations. Instead of promulgating rules pursuant to the Administrative Procedure Act, ${ }^{284}$ EPA now frequently issues guidance memoranda and directives. Also, many important agency rulings are not reflected in generic rulemaking, but in individual permit decisions. OMB oversight is thereby avoided, and judicial review of agency action is limited. ${ }^{285}$

Excessive congressional, $\mathrm{OMB}$, and judicial oversight also has resulted in poor allocation of agency resources and skewed national environmental priorities. Each overseer can use his or her leverage (that is, power to delay or reduce appropriations, hold up confirmation of agency appointments, create bad publicity, eliminate agency discretion, or impose appropriations riders to redefine agency priorities), ${ }^{286}$ but the end result is unlikely to reflect any broad or thoughtful determination of environmental priorities. In fact, quite the opposite is true.

Members of the House and Senate routinely respond to narrow parochial concerns and to their own need to receive maximum favorable publicity. ${ }^{287}$

281. Wilson, Bureaucracy at 32 (cited in note 16).

282. Feliciano, EPA: An Analysis of Its Controversies at 23-27 (cited in note 21); Yancy, CERCLA Evaluation at 110-13 (cited in note 233) (estimated percentage of time spent by EPA's Office of Waste Programs Enforcement on addressing congressional oversight, and therefore not available to develop enforcement orders, support pending litigation, or develop new enforcement cases: $50 \%$ in 1982; nearly $100 \%$ in early 1983 (before resignations); $25 \%$ in 1983 (following resignations and arrival of new agency appointees)).

283. See Walter Rosenbaum, The Politics of Environmental Concern 165 (Praeger, 1977).

284. 5 USC $\$ \$ 551.556$ (1988).

285. See Bryan G. Tabler \& Mark E. Shere, EPA's Practice of Regulation-by-Memo, 5 Natl Resources \& Envir 3 (Fall 1990); D.C. Circuit Asked To Remand EPA "Rule" Eliminating PRP Role In Risk Assessment, 5 Toxics L Rptr 884 (Dec 12, 1990); Burnham Corp. v EPA, 32 ERC 1666 (SD Ohio, Oct 25, 1990) (regulatory interpretation letter signed by assistant regional counsel not final agency action subject to judicial review).

286. See Dwyer, 17 Ecol L Q at 295 (cited in note 46) (power of individual committee members); Aberbach, Keeping a Watchful Eye at 7 (cited in note 164); see Foreman, Signals from the Hill at 105-58 (cited in note 36) (describing examples of appropriation riders limiting EPA authority); see, for example, HR Rep 101-490, 101st Cong, 2d Sess 145-46 (1990) (describing how Congress barred EPA from using appropriated funds to impose sanctions under the Clean Air Act on certain violators of the Act); EPA Nominees Break Free from Hold by Senator Concerned about Superfund Site, 10 Inside EPA 45 (Nov 24, 1989) (Sen. Metzenbaum placed "hold" on two nominees to assistant administrator positions at EPA until Administrator Reilly satisfied him that EPA would rectify specific problem at Superfund site in Ohio); see also, Tom Watson, Panel Cuts Budget In Showdown with Justice Department, Legal Times of Washington 17 (June 25, 1990) (recommending 10\% budget cut in Office of Legal Counsel because it issued opinion without prior opportunity for review by House subcommittee).

287. NAPA, Oversight Study at 26 (cited in note 162); id at 14 (maximum publicity and political advantage); id at 27-28 (statement of Lee Thomas, former EPA administrator: "[O]versight often becomes what I term a king of witch hunt oversight ... motivated, sometimes to a large extent, by an overzealous staff, sometimes by a member who is particularly interested in publicity."'); see also 
There is thus no reason to assume that the views of a particular subcommittee chair are consonant with those of Congress as a whole, ${ }^{288}$ or even consistent with the views simultaneously expressed by a different subcommittee. ${ }^{289}$ Oversight is likely to empower a few isolated interest groups that are able to persuade the chair to express their concerns to the agency. ${ }^{290}$ Indeed, a congressional subcommittee may be as likely as an agency, if not more so, to be "captured" by a special interest group. ${ }^{291}$

The competence of congressional staff to draft environmental legislation containing increasingly detailed prescriptions can also be questioned. Because authority among congressional committees is so fragmented, it is extremely difficult, if not impossible, for any one committee to undertake a broad, coordinated look at a complex problem. ${ }^{292}$ Rather, each committee tends to "view[] the bill through the narrow lens of its own particular mandate. None $\operatorname{tr}[i e s]$ to critically examine the structure of the program as a whole."293

Finally, there is also some reason for questioning the wisdom of exacting judicial review of EPA decisions. ${ }^{294}$ Commentators increasingly believe that the benefits of such review may have been overstated and the harms

Aberbach, Keeping a Watchful Eye at 46 (cited in note 164); Cynthia Farina, Statutory Interpretation and the Balance of Power in the Administrative State, 89 Colum L Rev 452, 509 (1989).

288. Farina, 89 Colum L Rev at 510 n248 (cited in note 287); Arthur MacMahon, Congressional Oversight of Administration: The Power of the Purse, in Theodore J. Lowi, ed, Legislative Politics 196 (Little, Brown, 2d ed 1965) ("The hazard is that a body like Congress, when it gets into detail, ceases to be itself; it acts through a fraction that may be a faction."). In ruling that EPA improperly relied on comments made during congressional oversight to support its rulemaking, the D.C. Circuit recently commented: "It should go without saying that members of Congress have no power, once a statute has been passed, to alter its interpretation by post-hoc 'explanations' of what it means." Hazardous Waste Treatment Council v EPA, 886 F2d 355, 365 (DC Cir 1989).

289. Agriculture-Environment and Consumer Appropriations for 1974, Part 5-Environmental Protection, Hearings before a Subcommittee of the House Committee on Appropriations, 98th Cong, Ist Sess 790 (1973) (testimony of Administrator William Ruckelshaus: "I think one of the dilemmas that $I$ am placed in is that $I$ appear before various committees of Congress. . . [F] lor me to try to make a recommendation to any committee of the Congress as to what we ought to do often flies right in the face of another committee's claim of jurisdiction.").

290. Randall L. Clavert, Mark J. Moran \& Barry R. Weingast, Congressional Influence over Policymaking: The Case of the FTC, in Matthew McCubbins \& Terry Sullivan, eds, Congress: Structure and Policy 514-15 (Cambridge U Press, 1987); see also Comment, The Hatfield Riders: Eliminating the Role of the Courts in Environmental Decision Making, 20 Envir L 329, 364, 369 (1990) (authored by Linda M. Bolduan) (improper empowerment of special economic interests); Dean Mann, Democratic Politics and Environmental Policy, in Kamieniecki, O'Brien \& Clarke, eds, Controversies in Environmental Policy 18-20 (cited in note 84) (fragmentation enhances ability of environmentalists to influence policy).

291. Lakshman Guruswamy, Integrating Thoughtways: Re-Opening of the Environmental Mind, 1989 Wis L Rev 463, 505 n196; see Paul Starobin, Merchant Marine: "Too Close to its Clients"?, 46 Cong Q Wkly Rptr 1559-63 (June 11, 1988); but see Jonathan Bendor \& Terry M. Moe, Agenda Control, Committee Capture and the Dynamics of Institutional Politics, $80 \mathrm{Am}$ Pol Sci Rev 1187, 1202-07 (1986) (interest group capture of congressional committee may be short-lived).

292. Aberbach, Keeping a Watchful Eye at 199-200, 208 (cited in note 164); see also Peter Strauss, Legislative Theory and the Rule of Law: Some Comments on Rubin, 89 Colum L. Rev 427, 450 (1989).

293. Landy, Roberts \& Thomas, EP.4: Asking the IVrong Questions at 164 (cited in note 32) (describing House consideration of Superfund legislation); Foreman, Signals from the Hill at 178 (cited in note 36) (with multiple overseers, there is " no overall sense of institutional priorities or collective endorsement of agency activity")

294. See text accompanying notes 152-56. 
underestimated. Some question the extent to which judicial review prompted process changes within the agency that may have improved its decisions. ${ }^{295}$ Other commentators question the competency of the courts to second-guess the policy judgments and complex technical determinations underlying EPA's major regulatory decisions. ${ }^{296}$ Still others point out that, because courts cannot choose the cases brought before them, they, unlike EPA, are unable to consider the "complex interactions among various cleanup strategies." 297 Finally, because courts are not in a position to make a considered judgment concerning how the agency might best allocate its limited resources among competing priorities, court orders force agency choices that may misallocate those resources. ${ }^{298}$

For all of these reasons, EPA's statutory priorities are diverging from the agency's own perception of the relative risks presented by various environmental hazards. Agency staff believe that too little attention has been paid to certain hazards and, at least in relative terms, too much to others. ${ }^{299}$ In addition, the demands for immediate results and agency action made by Congress and the courts have left EPA with little room for long-term planning, which, as noted above, is an essential aspect of environmental protection. ${ }^{300}$

295. Sanford E. Gaines, Decisionmaking Procedures at the Environmental Protection Agency, 62 Iowa L Rev 839, 904-05 (1977); Melnick, Regulation and the Courts at 241-42 (cited in note 8).

296. Dwyer, 17 Ecol L $Q$ at $311-12$ (cited in note 46) (agency better able to make policy decisions); Melnick, Regulation and the Courts at 14 (cited in note 8) (judge "uniquely unqualified"); see generally, Stephen Breyer, Judicial Review of Questions of Law and Policy, 38 Admin L Rev 363 (1986); Thomas O. McGarity, Regulatory Analysis and Regulatory Reform, 65 Tex L Rev 1243 (1987); Justice Antonin Scalia, Responsibilities of Regulatory Agencies under Environmental Laws, 24 Houston L Rev 97, 107-09 (1987); Peter L. Strauss, Considering Political Alternatives to "Hard Look" Review, 1989 Duke L. $\mathrm{J}$ 538; see also Illinois v Costle, 12 ERC 1597, 1599 (D DC 1979), affd sub nom Citizens for a Better Environment $v$ Costle, 617 F2d 851 (DC Cir 1980) ("I would urge upon the parties with everything at my command, that they consider the appropriateness of continuing to rely on courts to accomplish objectives which can only be effectively accomplished in a democracy by resort to the polls .... .").

297. Cass Sunstein, Law and Administration After Chevron, 90 Colum L Rev 2071, 2088 (1990) ("If the problems are treated separately, they will not be treated well.").

298. Natl Res Council, Decisionmaking at 69 (cited in note 97); Rosemary O'Leary, The Impact of Federal Court Decisions on the Policies and Administration of the U.S. Environmental Protection Agency, 41 Admin L Rev 549, 561-64 (1989); see EESI, Statutory Deadlines at ii (cited in note 49) (court deadlines more effective in prompting agency action than statutory deadlines).

299. EPA's 1987 report, Unfinished Business: A Comparative Assessment of Environmental Prionities, strongly suggests that the agency's priorities have been misdirected. Too little attention has been paid to certain hazards and environmental threats (such as hazardous air pollutants and indoor air pollutants), while relatively too much attention has been paid to others (including abandoned and inactive hazardous waste sites). Id at 95-97; EPA, Reducing Risk at 7 (cited in note 250). See generally, CEQ Sixteenth Annual Report at 27 (cited in note 53); Reitze, 14 Colum J Envir L. at $114-20$ (cited in note 250 ).

300. For example, the 1976 Resource Conservation and Recovery Act became a "selfperpetuating crisis" largely because of the absence of any broad, long-term congressional strategy concerning how best to manage this nation's generation of hazardous wastes. Landy, Roberts \& Thomas, EPA: Asking the Wrong Questions at 125 (cited in note 32). RCRA's short deadlines did not provide the agency with any meaningful opportunity to supply the necessary long-term perspective. They instead encouraged lawsuits against the agency, forcing the agency into incremental and premature decisions. Other commentators have remarked on the same phenomenon occurring within the context of EPA's implementation of the Clean Air Act. See Ackerman \& Hassler, Clean Coal, Dirty Air at 25 (cited in note 236); Bryner, Bureaucratic Discretion at 116 (cited in note 37). 


\section{Chilling of Innovation}

The worst result of the current administrative scheme is that it has undermined environmental protection by chilling agency and congressional innovation. Increased statutory prescription comes at the expense of agency discretion and flexibility. ${ }^{301}$ Intense agency oversight, repeated regulatory failure, and frequent controversy likewise discourage agency initiative. ${ }^{302}$

EPA officials have long recognized the need for administrative experimentation and reorganization. Congress, however, has increasingly denied the agency the option of exercising administrative innovation. Moreover, even when the opportunity remains, EPA officials have often shied away from innovation because of actual and anticipated objections from those elsewhere in the executive branch, the regulated community, Congress, and environmental organizations who are suspicious of the agency's motives.

For example, Congress's sharp restriction of agency discretion in its regulation of hazardous air pollutants under section 112 of the Clean Air Act has apparently prompted the agency to take less action than it might have under a more flexible statutory scheme. By mandating what is often infeasible, such as disallowing any significant consideration of economic costs, ${ }^{303}$ Congress prompted EPA to do very little ${ }^{304}$ EPA chose not to list a pollutant as "hazardous" in order to avoid triggering the statute's rigid requirements. ${ }^{305}$ The agency has consequently acted on only seven out of hundreds of toxic air pollutants over the last twenty years, ${ }^{306}$ leaving the others unregulated. ${ }^{307}$

The collision of institutional forces on Capitol Hill exacerbates matters by impeding the passage of new legislation. One obvious source of this problem is the sheer number of committees with overlapping jurisdiction, which can make it extremely difficult to pass a new law or a significant amendment to an existing law. For instance, conference committees for environmental statutes

301. See Paul R. Portney, Overall Assessment and Future Directions, in Portney, Public Policies for Environmental Protection at 286 (cited in note 11) ("The most important reason to be concerned about this recent trend is that flexibility and discretion are key to really effective environmental management. . . . [E]nvironmental problems are too diverse and complex for the use of uniform, across-the-board solutions."); see also Gene A. Lucero, Response to J. William Futrell, 24 Houston L Rev 143, 146 (1987) (Congress placed restriction on mixed funding settlement under CERCLA because of distrust of EPA).

302. See, for example, EPA, Program at a Crossroads at 8.9 (cited in note 110) (describing how intensive congressional oversight limited agency flexibility in RCRA implementation).

303. See Graham, 1985 Duke L J at 123, 130-32 (cited in note 190).

304. See EPA's Air Pollution Control Program: Hearings before the Subcommittee on Oversight and Investigation of the House Committee on Energy and Commerce, 98th Cong, 1st Sess 17-18 (1983) (testimony of EPA Administrator William Ruckelshaus) ("Where the mandates . . appear to suggest unfeasible programs, they tend to slow down, to 'study the problem', as the saying goes." ); see generally Dwyer, $17 \mathrm{Ecol} \mathrm{L} Q$ at 251-60 (cited in note 46).

305. Graham, 1985 Duke $L J$ at 117,124 (cited in note 190).

306. See S Rep No 101-490, 101st Cong, 2d Sess 151 (1990).

307. Congressional efforts to force EPA's listing of particular pollutants have not been especially effective. These efforts have led to disruptive litigation, compelled agency determinations in the absence of adequate scientific information, and diverted EPA resources from other problems (and other hazardous air pollutants), which might be more pressing. Id; Graham, 1985 Duke LJ at $126-27$ (cited in note 190). 
are often so large that they are unwieldy. Former EPA Administrator Lee Thomas described his "disgust" with the process of reauthorizing CERCLA in 1986: "We have six different committees on the House side and three or four on the Senate side and they all have created a camel that they are trying to make a race horse of. The end result is that they have spent a lot of time looking for a room big enough to hold everybody." 308 Efforts to amend the Clean Air Act in 1990 similarly became bogged down when nine senators and 132 members of the House were appointed to the conference committee. ${ }^{309}$ The legislation that finally emerges, as happened with the Clean Air Act, reflects an amalgam of special interests considerations rather than a coherent and comprehensive approach to the problem of air pollution. ${ }^{310}$

There are other casualties. EPA was long impeded in its efforts to develop an administrative program to address acid rain. ${ }^{311}$ There has been little concerted action to address global warming or indoor air pollution. Even a matter so seemingly uncontroversial as elevation of EPA to cabinet status, which had bipartisan support, ${ }^{312}$ became a victim of the same clash of institutional forces. Congress may pass the legislation sometime soon, but it will be long after the planned Earth Day 1990 (April 22) announcement. Like every other environmental initiative in recent years, the legislation became bogged down when controversies originating from the ongoing battle for control over EPA nearly overwhelmed the bill. President Bush threatened a veto when Congress proposed making the director of a "Bureau of Environmental Statistics" free from plenary presidential control. ${ }^{313}$ And there was widespread rebellion among certain congressional committees, OMB, environmentalists, and the regulated community concerning the proposed creation of a presidential commission to study administrative reorganization of federal environmental protection. All feared that any

308. Fiscal Year 1987 Appropriations Hearing at 160 (cited in note 204); see Atkeson, et al, 16 Envir L Rptr at 10369 (cited in note 189) (SARA conference in House and Senate took six months, and involved 19 Senators and 53 members of the House from 11 different committees)

309. Lengthy List of House Conferees Promises an Unwieldy CAA Conference. Most Say, 11 Inside EPA 13 (July 6, 1990).

310. Glicksman \& Schroeder, 54 L \& Contemp Probs at 285-86 (cited in note 39). Although fragmentation most often impedes passage of effective legislation, it may also, on rare occasions, actually facilitate passage of groundbreaking legislation that might otherwise have little chance of being enacted. Thus, when Senator Muskie effectively used his Air and Water Pollution Subcommittee to promote his aspirations for higher office though the Clean Air Act of 1970, fragmentation may actually have been a necessary feature of the background of the Air Act's passage. See E. Donald Elliott, Bruce A. Ackerman \& John C. Millian, Toward A Theory Of Statutory Evolution. The Federalization of Environmental Law, $1 \mathrm{~J} \mathrm{~L}$ Econ \& Org 313, 334 (1985).

311. Vig \& Kraft, eds, Environmental Policy in the 1980 s at 365 (cited in note 21) (epilogue); see Philip Shabecoff, Monitoring the Cleanup at the EPA; Ruckelshaus Postpones Plans to Curb Acid Rain, NY Times Al6 (Oct 23, 1983).

312. See Philip Shabecoff, Bush Would Agree to Elevate E.P.A., NY Times Al col 1 (Jan 22, 1990).

313. See HR Rep No 101-428, 101 st Cong, 2d Sess 25-29 (1990) (discussing proposed Bureau); House Overzuheimingly Passes EPA Cabinet Bill Despite White House Veto Threat, 11 Inside EPA 4-5 (April 6, 1990) (Bush veto (hreat). 
reorganization might adversely affect their jurisdiction, access, and ultimately their influence over the agency's operations. ${ }^{314}$

The significance of the pall of suspicion that has been cast over EPA initiatives and new legislative proposals extends, moreover, far beyond impeding presidential commissions. One of the most damaging effects may have been its thwarting of any meaningful EPA effort to implement a crossmedia approach, despite longstanding support for it within government and among commentators. ${ }^{315}$ As EPA's first administrator, William Ruckelshaus decided against organizing the agency along functional lines, which would have facilitated cross-media approaches, because of the possibility of engendering controversy in Congress. ${ }^{316}$ Ruckelshaus had early on borne the

314. During the summer of 1990 , Senate majority leader George Mitchell sought to break the legislative logjam related to internal disputes over turf between the Senate Government Affairs Committee, from which the bill originated in the Senate, and several Senate committees (Commerce, Science, and Transportation; Environment and Public Works; and Energy and Natural Resources), each of which had placed a "hold" on the bill because of their concern with its possible impact on their jurisdiction. See Majority Leader Intervenes to Break Senate Deadlock Over EPA Elevation Bill, 11 Inside EPA 3 (June 8, 1990). Similar committee jurisdictional concerns led to the defeat of President Nixon's proposal in 1971 to create four "supercabinets," including a Department of Natural Resources, see Dodd \& Schott, Congress and the Administrative State at 341 (cited in note 162), and have similarly thwarted efforts before and since to reorganize the federal natural resources administrative framework. See Harold Seidman, Politics, Position, and Power 46 (Oxford U Press, 2d ed 1975); Susan Abbasi, Environmental and Natural Resources Reorganization (Cong Res Serv, Feb 15, 1978) (Issue Brief No IB77106). See generally, Seidman, Politics, Position and Power at 37 (cited earlier in this note); Wilson, Bureaucracy at 221-22 (cited in note 16) (innovation always resisted by vested organizations). The issue that ultimately prevented passage of the EPA Cabinet legislation in 1990 concerned whether states should be allowed to impose civil penalties on federal facilities to force their cleanup of hazardous waste. See Michael Weiskopf, Drive to Elevate EPA to Cabinet is Stalled: Peripheral Issues Create Stalemate Between White House and Congress, Washington Post A 19 col 2 (Oct 12, 1990); EPA Cabinet Bill Dead This Year, Some Fault Administration Inaction, I 1 Inside EPA 3 (Nov 2, 1990). The same issue threatens passage of legislation elevating EPA this year (see Dingell, Commitment to Federal Facilities Provision, May Doom Cabinet Bill, 12 Inside EPA 19 (April 5, 1991)), but by late 1991 some form of legislation elevating the agency seemed ready to pass. On October 1, 1991, the Senate passed a "stripped-down" version of earlier bills, which eliminated some of the more contoversial provisions. See 137 Cong Rec S14012-32; Senate Passes EPA Cabinet-Level Bill, Adds Amendment on Statistics and Confidentiality, 22 Envir Rptr Curr Dev (BNA) 1407 (Oct 4, 1991). The House had not yet acted on the legislation at the time this article went to press.

315. See Reorganization Plan No 3 (cited in note 2) ("environment must be perceived as a single, interrelated system"); Guruswamy, 1989 Wis L Rev 463 (cited in note 291); Lakshman Guruswamy, Integrated Pollution Control: The Way Forward, 7 Ariz J Intl \& Comp L 173-202 (1990) (statement of EPA Administrator Lee Thomas) ("If the EPA is ever going to live up to its name in the fullest sense, if it is going to become more than a holding company for single medium programs, we are going to have to re-examine the roots of environmental policy."); Frances H. Irwin, Could There Be A Better Law, 15 EPA J 20-23 (1989); Marcus, Promise and Performance at 9-10 (cited in note 11); Landy, Roberts \& Thomas, EPA: Asking the Wrong Questions at 35 (cited in note 32); Single Statute Pushed by Reilly to Replace Existing Environmental Laws, 20 Envir Rptr Curr Dev (BNA) 1351 (Dec 1, 1989). A recent article outlines the basic disadvantages of a fragmented approach; these disadvantages include consideration of the impact of various inputs in the creation of residuals, holding the end product accountable for harmful residuals, looking at problems created by transfers from one medium to another, and dividing waste between three media to make optimal use of assimilative capacity of each. See Guruswamy, 1989 Wis $L$ Rev at 472-76 (cited in note 291). Professor Guruswamy eloquently argues that the agency should implement a cross-media approach by organizing itself along functional lines and abolishing its media-specific offices. Id at 536. See also Lakshman Guruswamy, The Case of Integrated Pollution Control, 54 L \& Contemp Probs 41 (Autumn 1991).

316. Ralph Nader's organization at the time appeared to be suspicious of an integrated approach and agency capture and, for this reason, promoted the more fragmented, media-specific approach. Guruswamy, $1989 \mathrm{~W}$ is $\mathrm{L} \mathrm{Kcv}$ at 487 (cited in note 291); see also Barry G. Rabe, Fragmentation and 
brunt of what he viewed to be a congressional misconstruing of agency motives, fueled by disgruntled agency employees. ${ }^{317}$ Once bitten, he shied away from other possible confrontations, ${ }^{318}$ arguably at the expense of implementing a far more rational and effective approach to pollution control. ${ }^{319}$

In addition, Ruckelshaus created a distinct problem for the agency by adopting what was supposed to be a temporary compromise approach under which functional and media-specific offices would exist side by side. The agency's persistent inability to move to a fully integrated organizational scheme has impeded effective decisionmaking. There is necessarily overlapping authority within the agency on all issues, and there has been a tendency for the two sides to take different approaches; the media-specific offices look to Congress for its signals, while the functionally defined offices look more to the executive branch. ${ }^{320}$ There is also a clash of disciplinary perspectives. ${ }^{321}$ The effect has been conflict and a decisionmaking process encumbered by efforts to include all interested parties within the agency in the process. ${ }^{322}$ It is settled EPA lore that internal agency meetings typically include fifty to one hundred of the agency's employees most expert on the issue to be debated. Not only are there multiple representatives from both the functional and media-specific offices but also individuals from the relevant regional and enforcement offices and from the General Counsel's office.

Other significant agency initiatives that have been impeded include the development of pollution prevention and market incentive programs. Both schemes hold considerable promise for improving environmental quality at lower cost. ${ }^{323}$ Each promotes the elimination of pollution at the source instead of through more costly end-of-pipe treatment. Both initiatives, however, depend on a departure from the command and control scheme for pollution control that has been the legislative touchstone for safeguarding against agency capture and neglect. ${ }^{324}$ More specifically, each requires providing the federal environmental agency with more discretion and flexibility to respond to case-specific factors. ${ }^{325}$ The existing polarization of

Integration in State Environmental Management 126-27 (Conservation Foundation, 1986) (environmental agencies and professionals, congressional committees, and environmental advocacy groups all had vested interests in the existing media-specific program and inherent suspicion of change).

317. Guruswamy, 1989 Wis L Rev 463 at 489 (cited in note 29l).

318. Marcus, Promise and Performance at 105-06 (cited in note 11).

319. The federal environmental statutes also discouraged a cross-media approach by focusing on specific media. See William F. Pedersen, Jr., Why the Clean Air Act Works Badly, 129 U Pa L Rev 1059, 1069-70 (1981).

320. Marcus, Promise and Performance at 101, 109 (cited in note 11).

321. McGarity, 54 L \& Contemp Probs at 62-64 (cited in note 272).

322. Id.

323. See EPA, Reducing Risk at 22 (cited in note 250).

324. Howard Latin, Ideal Versus Real Regulatory Efficiency: Implementation of Liniform Standards and "Fine-Tuning" Regulatory Reforms, 37 Stan L Rev 1267, 1271 (1985).

325. See generally Bruce A. Ackerman \& Richard B. Stewart, Reforming Environmental Law, 37 Stan L. Rev 1333 (1985); Schultze, The Public l'se of the Private Interest at 26-27 (cited in note 72); Stewart, 69 Cal L Rev at 1265, 1274-77 (cited in note 37); see also Davies \& Davies, The Politics of Pollution at 227 (cited in note 11 ). 
institutional forces has, however, prevented any meaningful effort to implement these alternative approaches. ${ }^{326}$ Many, but not all, environmentalists commonly equate any consideration of economics in the establishment of environmental standards or the use of market incentives for their achievement with caving in to industry. ${ }^{327}$ Hence, any agency step in that direction is typically met by a charge that the agency is undermining its public trust. Similarly, individual members of Congress have been so suspicious of EPA motives that a conflict has recently arisen with the agency concerning how best to organize the agency internally in order to emphasize pollution' prevention. ${ }^{328}$

\section{$\mathrm{V}$}

\section{Conclusion}

\section{Reversing the Cycle: Instilling Trust and Promoting Innovation}

Reversing the current pathological cycle of regulatory failure, crisis, and controversy will not be easy. Indeed, to some extent, the problems that have been realized in the implementation of federal environmental law bear an uneasy resemblance to those forecasted by William Ophuls in his impressive, albeit gloomy, essay, Ecology and the Politics of Scarcity. ${ }^{329}$ In that work, Ophuls suggested that democracy might have great difficulty fashioning technological solutions to the problems presented by ecological scarcity. He identified the potential problems associated with fragmented and dispersed policymaking responsibility; in particular, he questioned whether the public and its elected officials would be competent to make the correct technological decisions. ${ }^{330}$

Fragmentation of authority and the gap that Ophuls intimated might develop between technical "experts," on the one hand, and the public and its elected representatives, on the other, apparently emerged. The issues are complicated and perhaps too complex for many members of the public to grasp. Moreover, because the benefits of environmental controls are realized over generations while the cost to society is immediate, few politicians are likely to have the electoral incentives necessary to embrace the kinds of societal changes now needed. Finally, interest group politics, which have rooted themselves deeply into modern democratic political processes,

326. Congress did, however, enact a limited pollution prevention bill in the closing moments of the 101st Congress, entitled the "Pollution Prevention Act of 1990." See Pub L No 101-508, $\S \S 6601$ et seq, 104 Stat 1388 (1990); 136 Cong Rec H12517 (Oct 26, 1990). The new law provides for the establishment of an "Office of Pollution Prevention" within EPA and for that office to create a strategy to promote source reduction. The law also requires designated facilities to report on their level of source reduction and recycling.

327. Portney, ed. Public Policies for Environmental Protection at 128, 147 (cited in note 11); Carol M. Rose, Environmental Faust Succumbs to Temptations of Economic Mephistopheles, Or, Value By Any Other Name Is Preference, 87 Mich L Rev 1631, 1632-35 (1989). Environmentalists who work with industry are similarly susceptible to such charges. See EDF's Cooperative Approach To Industry Drau's Fire Among Environmentalists, 11 Inside E.PA 3 (Aug 24, 1990).

328. See Congressmen in Push . Mandatory High-Level EPA Pollution Prevention Office, 10 Inside EPA 5 (Nov 3, 1989).

329. William Ophuls. Ecology and the Politics of Scarcity (W. H. Freeman \& Co., 1977).

330. Id at 159-63. 193-95. 
exacerbate the problem by promoting incremental, fragmented decisionmaking.

In his essay, Ophuls presented what many might view as a Hobson's choice: either deemphasize technological solutions to environmental problems or replace democratic processes with elitist decisionmaking institutions. ${ }^{331}$ The choice, however, need not be so stark. Other valuable reforms can be undertaken; their implementation will engender resistance but not nearly to the same degree as Ophuls' choices, and some may succeed.

One such reform would be to reduce the level of distrust directed at EPA by other governmental institutions. Much of the distrust is derived from an intellectual mistake concerning the possibility of EPA's capture. Second, some of the unintended organizational mistakes of the past need to be redressed. With the benefit of hindsight, we can better organize the federal environmental protection agency, reducing conflict and facilitating environmental decisionmaking by the government. Finally, the existing gap between public aspirations for environmental quality and public understanding of the issues needs to be bridged, as does the gulf between public and agency perceptions concerning the nature of environmental risk.

\section{A. Dispelling the Myth of Agency Capture}

Much of the momentum behind the constant clashes that have marked EPA's existence originates in concerns about agency capture. ${ }^{332}$ These concerns have been needlessly destructive of effective environmental protection. There is good reason to believe that the risk of agency capture would be slight, even without the intense oversight mechanisms that various competing factions have utilized to prevent capture. Indeed, the only plausible justification for the intensity of each of those mechanisms is the threat now presented by the excesses of the others. For instance, OMB justifies its intense oversight as a necessary response to congressional supervision, while Congress justifies the intensity of its oversight in part as a response to the supervision of OMB.

No single interest group is likely to capture an agency with characteristics similar to those of EPA. Unlike the agencies considered by the original agency capture theorists, EPA has a "social mission"; and unlike agencies such as the Interstate Commerce Commission, EPA does not manage a distinct kind of economic activity. EPA is subject to a complex set of constituencies. There is no single dominant interest that threatens to capture the agency. ${ }^{333}$

331. Id at 159-63. Ophuls also describes the choice as being between "the minimal, frugal steady state," and "a degraded and tyrannical version of the steady state," and he warns that the latter "may become almost inevitable" if there is too much delay in our moving towards the former. Id at 243.

332. See text accompanying notes 10-41.

333. Dwyer, 17 Ecol L. Q at 278, 309-10 (cited in note 46). 
Contrary to the assumption of agency capture theory, ${ }^{334}$ public interest in environmental issues has not been fleeting. ${ }^{395}$ National environmental organizations have enjoyed sustained public support. Technological advances have greatly enhanced the ability of such citizen groups to marshall public support and to influence agency decisionmaking. ${ }^{336}$ And, conversely, the agency is itself capable of avoiding decay and capture by enlisting the environmental organizations in support of controversial agency actions. ${ }^{337}$

In the case of environmental protection, the regulated community or industry does not speak with one voice, as agency capture theory assumes. Because environmental protection laws sweep so broadly, those affected are an exceedingly diverse group. Accordingly, their interests frequently conflict, making capture improbable. ${ }^{338}$ Companies that have already invested substantial sums in pollution control are less likely, for instance, to support the relaxation of restrictions that would result in their competitors avoiding similar expenditures. ${ }^{339}$ Such companies generally desire regulatory stability. ${ }^{340}$ The manufacturers of pollution control equipment, a sizeable industry in itself, resist deregulatory efforts, as do states and localities, which have become dependent on federal largesse in aiding their own pollution control efforts. ${ }^{341}$

In addition, because employees of agencies like EPA tend to share the agency's social mission, ${ }^{342}$ the agency staff is less susceptible to ideological conversion by those regulated. ${ }^{343}$ Indeed, quite the opposite might be true.

334. Paul J. Quirk, Industry Influence in Federal Regulatory Agencies 14 (Princeton U Press, 1981).

335. Professor Jaffe, with characteristic omniscience, predicted that it would be "suicidal for the agencies to ignore ..." environmental protection, given the depth of public sentiment on the issue. Louis L. Jaffe, The Federal Regulatory Agencies in Perspective: Administrative Limitations in a Political Setting, 11 BC Indust \& Comm L Rev 565, 569 (1970). The impact of President Reagan's misreading of public opinion on the experiences of both Anne Gorsuch and James Watt testifies to the correctness of Jaffe's assertion. See George Cameron Coggins \& Doris K. Nagle, "Nothing Beside Remains": The Legal Legacy of James G. Watt's Tenure as Secretary of the Interior on Federal Land Law and Policy, 17 BC Envir Aff L Rev 473, 545-46 (1990); see also Robert C. Mitchell, Public Opinion and Environmental Politics in the 1970s and 1980s, in Vig \& Kraft, eds, Environmental Policies in the 1980s at 70-71 (cited in note 21) (discussing Reagan's misapprehension of public sentiment on environmental issues).

336. Guruswamy, 1989 Wis L Rev at 531 (cited in note 291); Paul Sabatier, Social Movements and Regulatory Agencies: Toward a More Adequate and Less Pessimistic Theory of "Clientele Capture," 6 Policy Sciences 301, 318 (1975); Wilson, Bureaucracy at 83-84 (cited in note 16).

337. See Paul Culhane, Federal Agency Organizational Change in Response to Environmentalism, 2 Humboldt J Soc Rel 31, 37 (1974); Sabatier, Social Movements and Regulatory Agencies at 304-05 (cited in note 336).

338. Ackerman \& Hassler, Clean Coal, Dirty Air at 119.20 (cited in note 236) (argues that there will always be some economic actors aligning themselves with environmentalists to try to impose pollution control costs on their competitors); Dwyer, $17 \mathrm{Ecol} L \mathrm{Q}$ at 310 (cited in note 46); Quirk, Industry Influence at 13-14 (cited in note 334).

339. Foreman. Signals from the Hill at 37 (cited in note 36); see also Coggins \& Nagle, 17 BC Envir Aff L Rev at 545-50 (cited in note 335).

340. See Stanfield, 18 Natl $\mathrm{L}$ J at 392 (cited in note 124). Hence, as EPA became more unstable under Anne Gorsuch, industry withdrew its support, notwithstanding its sharing of her deregulatory philosophy. See note 232.

341. Davies \& Davies, The Politics of Pollution at 114 (cited in note 11).

342. Wilson, Bureaurracy at 66-67 (cited in note 16); see text accompanying notè 265 .

343. For this same reason, the career staff at EPA is less susceptible to Professor Sax's concern that agencies will bargain away environmental values over time in a series of political compromises. 
The greater risk could be their tendency to discount the needs of the regulated, ${ }^{344}$ which serve as a useful counterweight to the inherent difficulty of evaluating environmental benefits. ${ }^{345}$ Nor, contrary to agency capture theory, ${ }^{346}$ does there appear to be any significant threat of agency corruption presented by the lure of career opportunities in the private sector. Past experience indicates that agency employees enhance their employment prospects by engaging in more aggressive action, rather than by appearing to coddle future employers. ${ }^{347}$

Finally, there may also be reason to question the traditional agency capture concerns underlying heightened judicial review of EPA decisionmaking. As one commentator has pointed out, the empirical data upon which the "new era of administrative law" was based looked mostly to "entrenched bureaucracies administering well-established programs." 348 Such agencies were faulted for failing to consider innovative techniques and for their relative timidity. ${ }^{349}$ EPA has never shown a systematic bias in favor of underachievement (fairly measured).

It is nevertheless difficult to be optimistic that oversight of EPA will become less intense or adversarial in the near future. To be sure, the judiciary already appears to have cut back on the degree of its scrutiny of agency decisionmaking. ${ }^{350}$ And there is reason to believe that Congress may

See notes 18-20 and accompanying text; Sax, Defending the Environment at 240 (cited in note 18) (noting that "the question we must ask ourselves is whether we are prepared to leave the public interest to hired hands"). Sax, who wrote his book before the creation of EPA, overestimates the value of judicial review and underestimates the significance of career staff; after all, the career staff supplied the information that was critical to the favorable judicial outcome in the case study that serves as the initial focus for Sax's thesis. See id at 21-30. The agency staff, not the court, is the true unsung hero in the narrative. Nevertheless, Professor Sax's thesis is the one among the various capture theories that appears to have continuing force even with EPA, although less than his argument might suggest.

344. Murray L. Weidenbaum, Business, Government, and the Public 21 (Prentice-Hall, 3d ed 1981).

345. The extent to which an agency employee's ideology affects her behavior within the agency is also far from clear. See Wilson, Bureaucracy at $5 \mathrm{l}$ (cited in note 16).

346. Quirk, Industry Influence at 164 (cited in note 334).

347. Id at 164-65, 172; Wilson, Bureaucracy at 86-87 (cited in note 16). My own observations of the field of environmental law are consistent with this view. The demand for environmental expertise has historically been so great (because enforcement has been so aggressive) that highranking governmental officials have enjoyed a bevy of job opportunities in the private sector. Similarly, there have been many instances of those in environmental groups moving to the private sector, notwithstanding their longstanding resistance of the short-term economic interests of industry. See, for example, Transitions, 7 Envir Forum 33 (Sep/Oct 1990) (reporting on the move of former senior attorney for the Natural Resources Defense Council's ("NRDC's") toxic substances program to Paul, Weiss, Rifkind, Wharton \& Garrison); Peter Carbonara, The Greening of Waste Management, 12 Am Lawyer 42 (Dec 1990) (description of former NRDC lawyer working for major corporation); W. John Moore, Greens Moving to Greener Pasture, 23 Natl J 746 (March 30, 1991) (NRDC co-founder joining $\mathrm{O}$ Melveny \& Myers law firm as partner).

348. Melnick. Regulation and the Courts at 3 (cited in note 8).

349. Id at 3-4.

350. Glicksman \& Schroeder, 54 L \& Contemp Probs at 296 (cited in note 39); Shapiro \& Glicksman, 1988 Duke LJ at 845-63 (cited in note 185). Professors Shapiro and Glicksman posit that Congress increased its own oversight and prescription partly in response to reduced judicial oversight without recognizing the connection between the judicial and legislative review. Id at 820 21. In an article in this symposium, Professo:s Glicksman and Schroeder argue in favor of 
succeed in reducing OMB's excesses, ${ }^{351}$ which may have the incidental effect of reducing Congress's incentive to engage in an unhealthy escalating competition with OMB for agency control.

The more likely result, however, is that Congress will prove to be a much tougher nut to crack. A shift in judicial philosophy has resulted because of the power of presidential appointment of federal judges. And if a change occurs with regard to OMB oversight, it will be because of Congress's great power over the purse strings. Realistically, there is currently no such countervailing authority in a position to compel Congress to change its ways.

Virtually every administrator has complained about the phenomena of fragmented congressional jurisdiction over EPA's programs, excessive congressional oversight, and the harm caused by the imposition of unrealistic deadlines. ${ }^{352}$ Despite the administrators' urging, the legislators have shown little disposition to improve the situation. ${ }^{353}$ Nor do the lawmakers appear to have any particular incentive to do so. ${ }^{354}$ Jurisdiction to oversee EPA provides an individual member of Congress with greater access to the news media, which is naturally attracted to the conflict and controversy associated

moderately aggressive judicial review. Glicksman \& Schroeder, 54 L \& Contemp Probs at 309 (cited in note 39 ).

351. Congress is presently considering legislation that would impose public disclosure of the particulars of $O M B$ review of agency rules, set deadlines for the completion of $O M B$ review, and require written explanation of all changes made by EPA to a rule in response to OMB comments. See House Panel Acts to Curb OMB Powers, Eslablish Federal Information Policies, 21 Envir Rptr Curr Dev (BNA) 1894 (March 23, 1990) (discussing HR 3695). President Bush may promulgate an executive order limiting $O M B$ review in an effort to defuse any such legislative initiative. See Congress, White House Agree on Executive Order to Limit OMB Review of EPA Regs, 11 Inside EPA 3 (July 20, 1990); see also note 134 .

352. See Bower \& Christenson, Public Management: Text and Cases at 114-15 (cited in note 14); Douglas M. Costle, A Regulator's Path Isn't a Rose Garden, NY Times E2 I (April 24. 1983); Abbott, 39 Admin L Rev at 204 (cited in note 280); Environmental Policy Division, Congressional Research Service of the Library of Congress, Congress and the Nation's Environment, Environmental and Natural Resources Affairs of the 92nd Congress, Senate Committee on Interior and insular Affairs, 93d Cong, 1st Sess 845 (1973); Peggy Wiehl, Ruckelshaus and EPA 13 (Harv JFK School of Gove, 1974); Reilly, The Turning Point at 1389 (cited in note 51). In 1978, the Administrative Conference recommended two alternatives to the type of rigid statutory deadlines that typify the federal environmental protection laws: (1) "Congress could by statute require agencies to establish their own deadlines for agency decisionmaking [which] would allow the agency (and also the oversight committees in the Congress) to monitor and review the agency's performance"; and (2) "Congress could assign a similar role to a statutory limit by providing that the time limit was not a matter of legal obligation but only established the normal time period during which Congress expected the agency to act." Edward A. Tomlinson, Report on The Experience of Various Agencies With Statutory Time Limits Applicable To Licensing Or Clearance Functions And To Rulemaking, in Administrative Conference of the United States, Recommendations and Reports 122 (Govt Printing Office, 1978).

353. Congress made some initial efforts in the mid-1970s to restructure its committee jurisdiction to diminish fragmentation of authority over environmental matters. Although the Senate did achieve some consolidation with the creation of the Senate Committee on the Environment and Public Works, a similar effort was defeated in the House, and fragmentation persists in both chambers today. See Dodd \& Schott, Congress and the Administrative State at 186-88 (cited in note 162); History of the Senate Committec on Environment and Public Works at 14-18 (cited in note 168). An earlier, more modest effort to create a joint committee on the environment likewise never bore fruit. See Environmental Policy Division at 833-36 (cited in note 38).

354. Dodd \& Schot, Congress and the Administrative State at 273, 326 (cited in note 162). 
with EPA. ${ }^{355}$ It also provides the legislator with enhanced leverage over the agency when responding to constituent concerns.

Hence, persuading the legislators that their initial agency capture concerns were largely illusory is unlikely to make much of an impression on the congressional psyche. Agency capture concerns have been replaced by interest group politics; and the latter and subcommittee government have formed a strong bond likely to resist successfully any efforts to reduce oversight through centralization and consolidation of EPA jurisdiction. Only across-the-board reform of congressional practices is likely to be sufficient, and there is nothing on the political horizon that appears likely to prompt such a dramatic and uncharacteristically altruistic step by Congress. ${ }^{356}$

\section{B. Reorganizing the Institutional Framework for Federal Environmental Protection to Eliminate the Vestiges of Distrust}

The practical hurdles that may prevent congressional reorganization of its own decisionmaking processes with regard to federal environmental policy need not preclude Congress and the White House from now revisiting how best to organize and structure a federal environmental agency. As described above, many of the compromises made by the White House in designing EPA in 1970 were made for narrow political reasons. These compromises have hindered EPA's operations and its delivery of federal environmental protection. It is now time for their undoing.

President Nixon rejected the option of making EPA a cabinet agency. As members of both parties now appear to recognize, EPA should be elevated to cabinet status. ${ }^{357}$ Contrary to what some might think, EPA's elevation would not be mere window dressing. It could provide a meaningful opportunity for agency renewal and a fitting occasion for reversing the pathological cycle of distrust that has plagued the agency over the last twenty years.

For example, the endorsement of the agency's mission implicit in such an elevation in status would likely reinvigorate the agency. Agency morale could

355. Id. See also NAPA, Oversight Study at 12 (cited in note 162). The increase in congrcssional oversight of EPA partly may have reflected a response to the 1982 elections in which there appeared to be a significant "green vote" backlash to Secretary of the Interior Watt and EPA Administrator Gorsuch. See Michael E. Kraft, A New Environmental Political Agenda: The 1980 Presidential Campaign and Its Aftermath, in Vig \& Kraft, eds, Environmental Policies in the 1980s at 45-47,67-70 (cited in note $21)$. Elected representatives prefer high visibility committees with jurisdiction over pressing national issues like environmental protection. See Barbara Sinclair, The Distribution of Committee Positions in the United States Senate: Explaining Institutional Change, $32 \mathrm{Am} J$ Pol Sci 276, 297 (1988); see also Charles S. Bullock, United States Senate Committee Assignments: Proference, Motivation, and Success, 29 Am J Pol Sci 789 (1985)

356. I address the issue of congressional oversight and the kinds of reforms that would be necessary in greater depth later in this same symposium issue in Lazarus, $54 \mathrm{~L}$ \& Contemp Probs 205 (cited in note 161). The National Academy of Public Administration recently issued a report in which it studied congressional oversight of several agencies, including EPA, and made a series of recommendations for congressional reform of its oversight practices. Those recommendations seek, inter alia, to address problems caused by fragmented committee jurisdiction and by the absence of systematic, coordinated oversight. See generally NAPA, Oversight Study (cited in note 162).

357. At the time this symposium issue went to press, Congress seemed close to passing the needed legislation. See note 314. 
significantly improve, which would in turn enhance employee retention and recruitment. ${ }^{358}$ It would also have the added benefit of ameliorating some of the agency's historical problems. The agency's leverage within the executive branch would be greater, making it theoretically less subject to OMB's influence and providing the agency head with more ready access to the President when controversies arise. ${ }^{359}$ In addition, because EPA's elevation would increase the prestige and visibility of a presidential appointment at the new agency, the reorganization might make it more likely that those nominated and confirmed to top positions are reasonably capable. ${ }^{360}$

The creation of a cabinet-level EPA would be one important step, but more would be necessary to redress the institutional vestiges of past political compromises. In particular, fragmentation of environmental protection authority within the executive branch needs to be reduced. To be sure, fragmentation probably can never be eliminated, given the huge scope of activities affecting environmental quality. ${ }^{361}$ But the degree of fragmentation can be substantially lessened, with a concomitant increase in integration and decrease in interagency conflict.

To that end, serious consideration should now be given to transferring to the new department the various pollution control activities that have remained in agencies other than EPA. The National Oceanic and Atmospheric Agency ("NOAA") is a good example. NOAA is currently within the Department of Commerce largely as a byproduct of President Nixon's 1970 compromise with Commerce Secretary Maurice Stans, who was concerned about Nixon's creation of EPA. ${ }^{362}$ It would seem sensible to combine EPA's and NOAA's two jurisdictions in one cabinet department. ${ }^{363}$ A strong argument can likewise be made in favor of merging into that same

358. No less significant in terms of boosting agency morale, self-confidence, and employee recruitment would be moving the agency to a new, less depressing physical location. All who have worked or spent any significant time at the agency recognize the need for such a move, which seems increasingly likely. See Nomination of William K. Reilly at 145 (cited in note 35); see also EPA Employees File $\$ 35$ Million Negligence Suit Alleging Air In Workplace Is Contaminated, 5 Toxics L Rptr 847 (Dec 5, 1990) (Bahura v S.E.W. Investors, No 90-CA10594 (DC Super Ct, answer filed Oct 26, 1990)).

359. The problems associated with the absence of cabinet status were compounded under Anne Gorsuch; the EPA, lacking cabinet status, was not a member of the president's Cabinet Council on Natural Resourres, which was chaired by Interior Secretary Watt. See Landy, Roberts \& Thomas, EPA: Asking the Wrong Questions at 248 (cited in note 32). In addition, although Administrator Reilly has been invited to sit at cabinet meetings, see Trip Gabriel, The Greening of the White House, NY Times Magazine 25 (August 13, 1989); Nomination of William K. Reilly at 41.42 (cited in note 35), these invitations are not the equivalent of regular membership in the cabinet. Invitees are aware of their status and rarely volunteer comments. Seidman, Politics, Position, and Power at 210 (cited in note 314).

360. See Lash, Gillman \& Sheridan, $A$ Season of Spoils at 10 (cited in note 214); Note on the EPA under Administrator Anne Gorsuch 3 (Harv JFK School of Govt, 1984) (N16-84-587) (Gorsuch reportedly upgraded when others rejected job).

361. Davies \& Davies, The Politics of Pollution at 118 (cited in note 11); see also Guruswamy, 1989 Wis L Rev at $483 \mathrm{n} 91$ (cited in note 291).

362 . See text accompanying notes 24,26 .

363. Congress is presently contemplating placing NOAA within the new Department of Environmental Protection. Several former NOAA officials testified before Congress in May 1990 that such a shift would assist NOAA. Ironically, one of the larger remaining hurdles is congressional committee jurisdiction. Congress Begins Talks on Making NOAA Part of EPA, More Likely Staff Says, 11 Inside EPA 9-10 (May 18, 1990) ("One EPA source suggests a merger of EPA and NOAA could have 
department another relic of past political compromise: the Army Corps of Engineers' jurisdiction over wetland pollution. ${ }^{364}$ Other areas of federal environmental protection jurisdiction whose transfer to a Department of Environmental Protection could achieve greater integration and reduce conflict include: surface mining control at the Office of Surface Mining in the Department of the Interior, endangered species protection at the Fish and Wildlife Service in Interior, remaining parts of the pesticides program still at Agriculture and elsewhere, ${ }^{365}$ and pollution control aspects of scattered programs within the Department of Energy and the Nuclear Regulatory Commission. Greater consolidation of authority is needed if the new department is going to fulfill its stated mission of being responsible for fashioning pollution control standards, including those ultimately applicable to federal as well as private activities.

Within the existing agency, a shift in perspective may now be in order. While the current media-specific, command and control approach has certainly achieved much success, the returns are diminishing. The current system is very inefficient, at times counterproductive, and ultimately defended as the most we can do in a "second-best" world. The perceived advantages of organizing the agency by function to facilitate a cross-media approach may be substantial; and, even if overstated, ${ }^{366}$ they are promising enough to be worthy of greater emphasis and experimentation. ${ }^{\mathbf{3 6 7}}$

One lesson of the last twenty years is that such a programmatic shift may also diminish the conflicts underlying EPA's pattern of regulatory failure. Much of that conflict is invited by each decisionmaking unit considering the impact of its decision only on one specific medium, to the detriment of different media about which a different decisionmaking unit is concerned. EPA's current organization exacerbates the problem by promoting further conflict between decisionmaking units by organizing them (in parallel) based on both media and function. ${ }^{368}$ Reorganizing the agency by function to facilitate a cross-media approach would likely eliminate many of these past sources of conflict and facilitate and expedite agency decisionmaking.

taken place a dozen years ago if advocates could have found a way around committee 'parochialism' that leads members of Congress to defend their committee's jurisdiction at all costs.").

364. Michael C. Blumm \& D. Bernard Zaleha, Federal Wetlands Protection Linder the Clean Water Act: Regulating Ambivalence, Intergovernmental Tensions, and A Call for Reform, $60 \mathrm{U}$ Col L Rev 695, 771-72 (1989).

365. Rodgers, 3 Environmental Law $\$ 5.1$, at 19 (cited in note 82) (describing how research responsibilities and risk assessment duties in pesticide control remain scattered among offices at EPA, Occupational Safety and Health Administration, State, Forest Service, and Agriculture).

366. Latin, 37 Stan L Rev at 1267 (cited in note 37).

367. For an especially lucid presentation of the advantages of a cross-media approach, including some of the associated difficulties of agency re-organization, see Guruswamy, 1989 Wis L Rev at 49899, 536 (cited in note 291); see also Thomas L. Adams \& Kyle E. McSlarrow, Seizing 1989 As A Window of Opportunity: An Environmental Challenge to the Next Administration, 18 Envir L Rptr 10419, 10420 (1988); William Reilly, The Greening of EPA, 15 EPA J 8, 10 (1989).

368. A recent study on EPA agrees that this source of conflict should be eliminated, but recommends the elimination of the functional categories instead. See Landy, Roberts \& Thomas, EPA: Asking the Wrong Questions at 298-99 (cited in note 32). 
Another change needed within the agency itself is greater emphasis on long-term planning. A major casualty of the current scheme is that it has discouraged meaningful long-term planning; in the case of environmental protection policy, that discouragement can be a recipe for disaster. Serious consideration should be given to the creation of a specific office within a cabinet-level EPA dedicated to long-term planning. ${ }^{369}$ There also needs to be a parallel effort to encourage career employees, especially those professionals with technical expertise, to remain at the agency, where turnover has historically been high. Otherwise the agency will lack the continuity of technical expertise necessary for the creation and subsequent infusion of long-term planning within the agency. The National Academy of Public Administration recently offered several recommendations concerning incentives that might lessen turnover at EPA. ${ }^{370}$

Finally, the institutional framework within the Executive Office of the President warrants modification. OMB has been the lead unit within the EOP during EPA's twenty years, while the president's Council on Environmental Quality ("CEQ") has had a diminishing voice. As a result, one perspective dominates the dialogue with EPA; because of OMB's basic opposition to the precepts underlying the federal environmental laws, the upshot has been an unhealthy, escalating competition with Congress for agency control.

Reduction of OMB's oversight is one option, ${ }^{371}$ but a complementary, and perhaps more significant measure, would be to establish a more balanced voice within EOP itself. ${ }^{372}$ There is, at bottom, a pressing need for an "environmental policy decisionmaking unit" within EOP to serve the clearinghouse function that OMB has served, but with a broader outlook. ${ }^{373}$ There needs to be an office within EOP with the clout of the Council of Economic Advisors or even the National Security Council that is in a position to give thoughtful consideration to the many environmental protection issues that cut across important questions of national policy. ${ }^{374}$ Environmental

369. Professors Bruce Ackerman and William Hassler made a similar recommendation in the aftermath of their study of EPA decisionmaking in mandating the use of scrubbers for air pollution control. See Ackerman \& Hassler, Clean Coal, Dirty Air at 128 (cited in note 236).

370. One recommendation provided greater opportunity for advancement through the conversion of certain high-level positions from political appointments to career slots. See NAPA, Steps Toward A Stable Future at 4 (cited in note 265); see also Committee Report at 17 (cited in note 247). Recent legislative proposals for EPA's elevation to cabinet status included a provision that served that end. It discouraged the filling of certain positions based on political affiliation and provided that governmental service in environmental affairs is a qualification for the job. See HR Rep No 101-428 at 22 (cited in note 313). The version of EPA cabinet legislation recently passed by the Senate, however, included no such provision. See 22 Envir Rptr Curr dev (BNA) 1407 (cited in note 314$)$.

371. See note 351 .

372. The Domestic Policy Office devotes minimal staff to the issue and, as a result, simply looks to OMB and EPA for guidance. See Bach, Government Constraints at 176-77 (cited in note 35).

373. See J. Michael McCloskey, Reorganizing the Federal Environmental Effort, 11 Duquesne L Rev 484 (1973); see also Sierra Club $y^{\prime}$ Cosile, 657 F2d 298, 406 (DC Cir 1981) ("An overworked administrator exposed on a 24-hour basis to a dedicated but zealous staff needs to know the arguments and ideas of policymakers in other agencies as well as in the White House.").

374. See 136 Cong Rec S8930 (June 28, 1990) (remarks of Sen. Nunn: "However, I am persuaded that there is also a new and different threat to our national security emerging-the 
protection must become fully integrated in the workings of the entire federal government-ranging throughout the implementation of federal tax, energy, agriculture, and international policies ${ }^{375}$-which is a task beyond the capability of any one agency outside the EOP. A reinvigorated CEQ could play that role, but the council has historically failed to do so. ${ }^{376}$

Finally, presidential leadership on environmental issues will be required. Presidents have historically been less sensitive to environmental protection matters and more attune to shifts in national economic indicators. This may in part be because the electorate has traditionally held the President more accountable for the performance of national economic indicators, or at least for the effects of their performance on economic measures that strike voters more closely to home, such as stock market activity and interest rates. To provide the President with the proper incentive, national economic indicators need to be modified to take into account the impact of environmental pollution and resource utilization on the nation's environmental wealth. For instance, as recently described by EPA's Science Advisory Board, "[n]ational accounting schemes typically characterize revenue generated by activities that deplete or degrade environmental resources as 'income' while failing to consider the resulting depletion of society's environmental capital asset." 377 To promote presidential environmental leadership, EPA needs to make it a high priority to develop a methodology to redress this discrepancy in national economic indicators. ${ }^{378}$

\section{Bridging the Gap Between Public Aspirations and Understanding and Public and Agency Perception of Environmental Risk}

Only public education, including a sustained effort to promote environmental literacy in the public, will bridge the gap that has persisted between public aspirations for environmental quality and public understanding of the complexity of the associated trade-offs. Only bilateral education of both the public and EPA will bridge the recent gap that has developed between agency and public perception of the nature of environmental risk and of environmental protection priorities.

A revolution has taken place in this nation's environmental laws over the last twenty years. No accompanying revolution occurred, however, in the nation's classrooms to enhance the public's appreciation of the underpinnings

\footnotetext{
destruction of our environment."); National Defense Authorization Act for Fiscal Year 1991, S Rep No 101-384, 101st Cong, 2d Sess 223 (1990) ("The committee believes that threats to the environment should be regarded as national security threats . ...").

375. EPA, Reducing Risk at 6 (cited in note 250).

376. Bach, Governmental Constraints at 174 (cited in note 35); Davies \& Davies. The Politics of Pollution at 120 (cited in note 11); Reitze, 5 Colum J Envir L at 120-21, 151-52 (cited in note 250). 377. EPA, Reducing Risk at 15 (cited in note 250).

378. Considerable ongoing research exists in this area, and several European nations are apparently experimenting with alternative methods of national accounting that better reflect costs of resource depletion. See Marlise Simons, Europeans Begin To Calculate The Price Of Pollution, NY Times E3 col 1 (Dec 9, 1990); Peter Passell, Rebel Economists Add Ecological Cost To Price Of Progress, NY Times Cl col 4 (Nov 27, 1990).
} 
of the environmental laws and their ramifications. More environmental educators and fewer environmental lawyers are now necessary. Creative environmental curricula need to be developed and made a regular part of secondary school education. The subject matter warrants intensive coverage as an independent course in every student's curriculum. ${ }^{379}$

Public education will also do much to bridge the gap between public and agency perceptions of environmental risks and priorities, but more than that will be necessary. The gap finds its roots in the very different perspective each brings to the pollution problem. Much of the public starts with the premise that pollution is morally and culturally unacceptable; by contrast, the agency professional seeks to determine the optimal level of pollution for a specific human activity at a particular location. Little common ground exists at the outset, and whatever there might have been is quickly lost in the aftermath of repeated agency regulatory failure and its repeated denunciation by elected representatives, environmentalists, and industry. ${ }^{380}$

To bridge the existing chasm, EPA must supplement formal public education with candid explanations of the competing factors, including the scientific uncertainty underlying its decisions. ${ }^{381}$ In addition, EPA must not view the dialogue with the public as a one-way street, with the "expert" agency having the responsibility to educate the "ignorant" public. The success of a program of public risk management depends on its acceptance by the public. EPA therefore must educate itself about public perception of risk at the same time that it seeks to enhance the public's understanding of the agency's perspective.

Risk assessment is not simply a technical matter. It also depends on value judgments that turn on basic notions of justice and equity. Both EPA and the public therefore have much to learn from each other ${ }^{382}$ Moreover, when EPA ignores the public's distinct perception of risk, the agency's resolution of acceptable levels of risk and relative agency priorities will find little acceptance where the agency needs it most: in the public. ${ }^{383}$ If nothing else,

379. Happily, on November 16, 1990, President Bush signed the National Environmental Education Act, which should further these ends. See Pub L No 101-619, 104 Stat 3325. The new law establishes, inter alia, an Office of Education within EPA, an environmental education and training program, an environmental education grants program, an environmental internship and fellowship program, an Environmental Education Advisory Council and Task Force, and a National Educational Training Foundation. See 136 Cong Rec S17160 (Oct 27, 1990).

380. Compare Elliott, 25 Houston L Rev at 797 (cited in note 276).

381. See Landy, Roberts \& Thomas, EPA: Asking the Wrong Questions at 279-80 (cited in note 32); see also Natl Res Council, 2 Decisionmaking in the Environmental Protection Agency at 7-8 (cited in note 97) (need for public candor concerning scientific uncertainty).

382. EPA, Reducing Risk at 12 (cited in note 250),

383. In a recent article, Professors Gillette and Krier make a forceful case for the proposition that federal agencies might systematically make decisions in favor of too much risk, as viewed from the public's perspective. Systematic bias is likely because risk producers have greater access to the administrative process thán do risk consumers, and because agency officials commonly refuse to acknowledge the ethical and political dimensions of public risk that are of concern to the public. See Gillette \& Krier, 138 U Pa L Rev at 1027, 1061, 1068, 1085 (cited in note 261). Gillette and Krier argue that the present challenge of public risk management "is to devise solutions as powerful as the programs they confront. We need to imagine institutional breakthroughs that match our 
the last twenty years make clear that EPA cannot afford the tragedy associated with that result.

technological ones, and we may need a new politics to replace the old." Id at 1109 . Professor Donald Hornstein likewise warns against undue reliance on comparative risk analysis as part of his even broader critique of such analysis based on its inability to accommodate either relevant equitable considerations or legitimate public judgments regarding risk. See Donald Hornstein, Reclaiming Environmental Law: A Normative Critique of Comparative Risk Analysis, Columbia L J (forthcoming 1992). 